
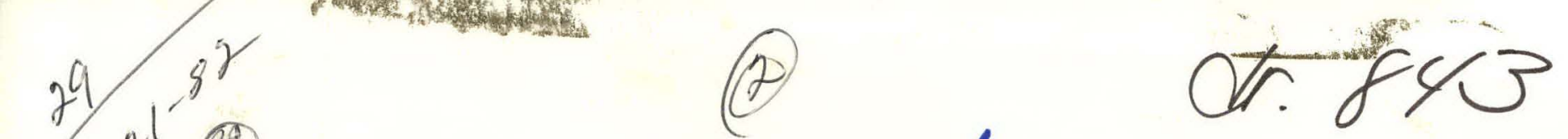

'

$\pm-5466$

ORNL/TM-8285

\section{Electron Spectra from Decay of Fission Products}

J. K. Dickens

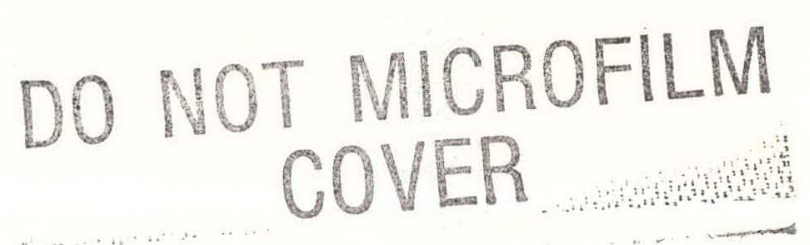

OPERATED BY

UNION CARBIDE CORPORATION FOR THE UNITED STATES DEPARTMENT OF ENERGY 


\section{DISCLAIMER}

This report was prepared as an account of work sponsored by an agency of the United States Government. Neither the United States Government nor any agency Thereof, nor any of their employees, makes any warranty, express or implied, or assumes any legal liability or responsibility for the accuracy, completeness, or usefulness of any information, apparatus, product, or process disclosed, or represents that its use would not infringe privately owned rights. Reference herein to any specific commercial product, process, or service by trade name, trademark, manufacturer, or otherwise does not necessarily constitute or imply its endorsement, recommendation, or favoring by the United States Government or any agency thereof. The views and opinions of authors expressed herein do not necessarily state or reflect those of the United States Government or any agency thereof. 


\section{DISCLAIMER}

Portions of this document may be illegible in electronic image products. Images are produced from the best available original document. 


\section{Printed in the United States of America. Available from National Technical Information Service \\ U.S. Department of Commerce \\ 5285 Port Royal Road, Springfield, Virginia 22161 \\ NTIS price codes-Printed Copy: A06; Microfiche A01}

This report was prepared as an account of work sponsored by an agency of the United States Government. Neither the United States Government nor any agency thereof, nor any of their employees, makes any warranty, express or implied, or assumes any legal liability or responsibility for the accuracy, completeness, or usefulness of any information, apparatus, product, or process disclosed, or represents that its use would not infringe privately owned rights. Reference herein to any specific commercial product, process, or service by trade name, trademark, manufacturer, or otherwise, does not necessarily constitute or imply its endorsement, recommendation, or favoring by the United States Government or any agency thereof. The views and opinions of authors expressed herein do not necessarily state or reflect those of the United States Government or any agency thereof. 
ORNL/TM- -8285

DE82 021114

Engineering Physics Division

\title{
ELECTRON SPECTRA FROM DECAY OF FISSION PRODUCTS
}

\author{
J. K. Dickens
}

Manuscript Completed - July 26, 1982

Date Published - September 1982

NOTICE This document contains information of a preliminary nature. It is subject to revision or correction and therefore does not represent a final report.

Prepared by the OAK RIDGE NATIONAL LABORATORY

Oak Ridge, Tennessee 37830 operated by

UNION CARBIDE CORPORATION

Under Contract No. W:7405-eng-26

for the

Division of Basir. Fnergy Scrienres

U.S. DEPARTMENT OF ENERGY 
THIS PAGE

WAS INTENTIONALLY

LEFT BLANK 


\section{CONTENTS}

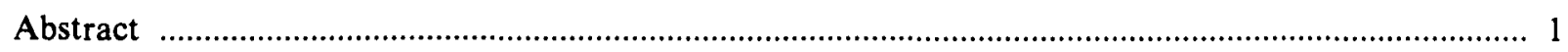

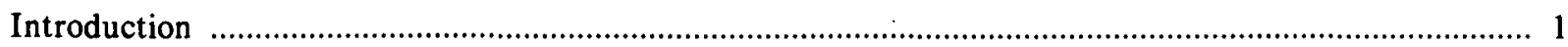

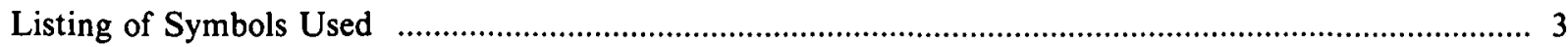

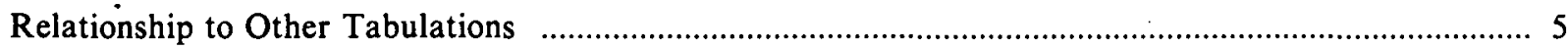

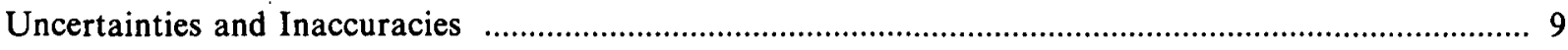

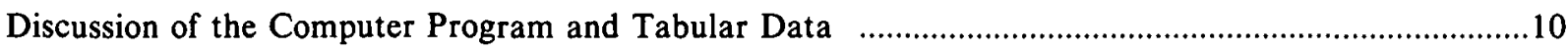

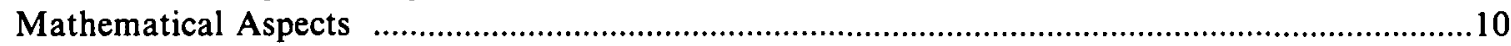

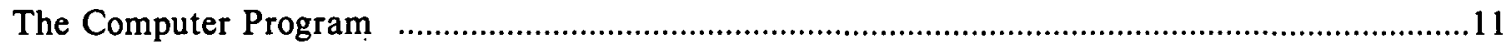

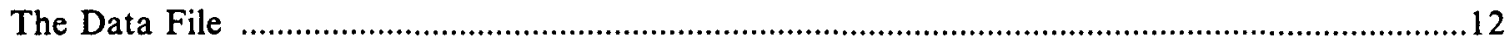

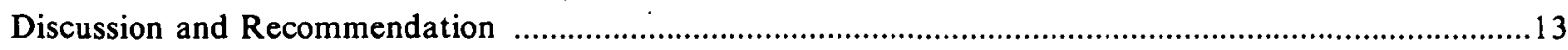

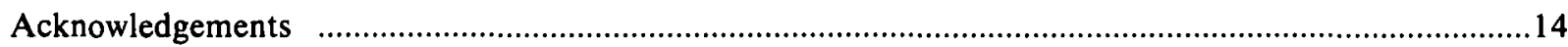

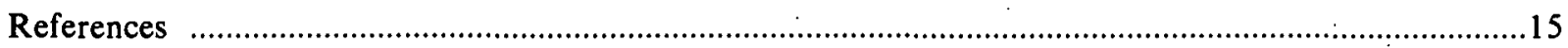

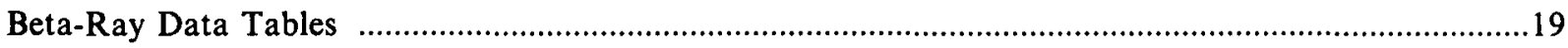

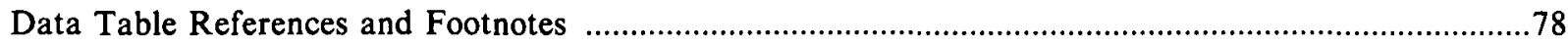

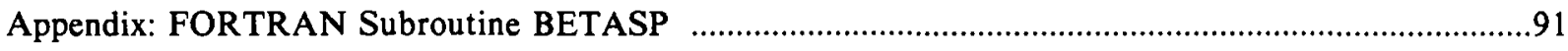




\title{
ELECTRON SPECTRA FROM DECAY OF FISSION PRODUCTS
}

\author{
J. K. Dickens
}

\begin{abstract}
Electron spectra following decay of individual fission products $(72 \leqslant A \leqslant 162)$ are obtained from the nuclear data given in the compilation using a listed and documented computer subroutine. Data are given for more than 500 radionuclides created during or after fission. The data include transition energies, absolute intensities, and shape parameters when known. An "average" beta-ray energy is given for fission products lacking experimental information on transition energies and intensities. For fission products having partial or incomplete decay information, the available data are utilized to provide best estimates of otherwise unknown decay schemes. This compilation is completely referenced and includes data available in the reviewed literature up to January 1982.
\end{abstract}

\section{INTRODUCTION}

Recent measurements ${ }^{1-4}$ of beta-ray spectra from decay of unseparated fission products created by thermal-neutron fission of ${ }^{235} \mathrm{U}$ and ${ }^{239,241} \mathrm{Pu}$ have been reported. These data were measured primarily to obtain (a) information about the associated reactor antineutrino spectrum ${ }^{\prime}$ for fundamental experiments involving antineutrino interactions ${ }^{5,6}$ and (b) information about the residual total decay energy of the fission products which are in reactor fuel elements following shutdown. ${ }^{2}+$ The total energy is essentially a heat source to be dealt with at times following shutdown of the reactor.

The experimental data of refs. 1-4 may be utilized directly to obtain the desired information for the tntal fission-product decay energy and indirectly to obtain the desired information on the reactor antineutrino spectrum. Perhaps more important, however, is that these data provide defacto benchmarks for testing results of computer programs ${ }^{7-15}$ designed to compute total (or partial) fissionproduct energy releases by cumulating individual energy releases that are calculated for each one of the fission products. Such a calculational program would ultimately be applied to complex conditions once it has been proven by favorable comparisons of calculated "data" with experimental data from these controlled experiments. ${ }^{1-4}$ To a large extent, the various computer codes yield very similar results when 
each one utilizes the same evaluated data base; it is, in fact, differences in evaluated data which result in differences in calculated results (e.g., Fig. 5 of ref. 15).

There are several different sets of evaluated data presently available, ${ }^{16-21}$ and for many fission products the evaluated data agree among the various sets. For computations of beta-ray energy release as a function of time following shutdown of a reactor, various data sets give more-or-less reasonable results. ${ }^{22}$

Calculating beta-ray spectra has proved to be more of a challenge, however, and much more sensitive to differences in the various evaluations. In particular, the computation of the high-energy response depends, to a large extent, upon assumptions about the decay transitions of those fission products for which there are no complete measurements of beta or gamma rays or of level structures from particle reaction experiments. These are the neutron-rich fission products well off the line of stability, having short half-lives and large values of energy available for beta decay $\left(Q_{\beta}\right)$. Ultimately, such nuclides will be studied in detail, and the decay characteristics will be determined. For the present, estimates must be made based upon fragmentary experimental data, or else upon theoretical considerations usually based on the systematic behavior of observed beta decay.

The present compilation was prepared specifically for the purpose of nhtaining spestra of beta rays due to decay of individual radionuclides produced in fission. It is an independent evaluation of existing published data and of other published compilations of existing data. There are several important points to bear in mind when using the present evaluation. The first is that of $\sim 200$ experimental decay schemes exhibiting detailed and complete results for beta-ray transitions fewer than 30 have generally available measured complete beta-ray spectra. ${ }^{23}$ Nearly all of the reported $E_{\beta}$ and $A_{\beta}$ have been deduced from gamma-ray measurements, and these deduced $E_{\beta}$ and $A_{\beta}$, as noted recently in several reports, ${ }^{23-25}$ could be in substantial error. Also important from the present point of view, however, is that even given the accuracy of the deduced $E_{\beta}$ and $A_{\beta}$ one must still compute the expected beta-ray spectrum, and this computation must be done without knowledge of the detailed shape of any individual spectrum for any one of the beta-ray transitions which make up the total spectrum. This lack of information is a second point to be considered. A third point is that deducing $E_{\beta}$ and $A_{\beta}$ from detailed 
gamma-ray placements and intensity balances often leads to assignments of beta-ray transitions having small $A_{\beta}$ (i.e., $<1 \%$ of the total decay). Such weak beta-ray transitions may not actually exist. However, even given the accuracy of these assignments, one can group together several very weak transitions or include several weak transitions as part of a close-lying strong transition, and calculations will yield a computed total beta-ray spectrum that will be essentially indistinguishable from a total spectrum in which every postulated beta-ray transition is separately computed.

The present goal is to compute total beta-ray spectra for all important individual radio-fission products. In view of the uncertainties inherent in such computations, the present evaluation has, on the one hand, simplified many of the reported complex decay schemes, while on the other hand provided somewhat speculative information about decay schemes for those fission products lacking complete experimental decay schemes. The correct shape [i.e., the distribution of emitted beta-rays $N(E)$ vs $E$, for a given transition] is computed when known ${ }^{26}$ or can be deduced from known spin-parity changes. For those fission products lacking any experimental information which could assist in determining a total beta-ray spectrum, an average beta-ray energy, $\left\langle\mathrm{E}_{\beta}\right\rangle$, is tabulated, and this datum is used in the spectrum calculation. Specifically, it is assumed that $\left\langle\mathrm{E}_{\beta}\right\rangle$ corresponds to the average energy of a single, allowed transition. ${ }^{27}$

The format of the basic data in the present tabulation is easy to understand, and it allows for ease in upgrading as new experimental or better evaluated basic data become available. The subroutine is written in standard FORTRAN and should be readily adapted to any system containing a standard compiler.

\section{LISTING OF SYMBOLS USED}

$\mathrm{A}_{\beta} \quad$ Absolute intensity of a given beta-ray transition as a percentage of the total radionuclide decay

$\mathrm{A}_{\gamma} \quad$ Absolute intensity of a given gamma-ray transition as a percentage of the total radionuclide decay 
$a_{i} \quad$ Coefficients for analytic expression of $S_{n}$

$\mathbf{B}_{n} \quad$ First-neutron separation energy in the daughter radionuclide

E Response kinetic energy of a measured beta ray, $O \leqslant E \leqslant E_{\beta}$ (all energies are in $\mathrm{MeV}$ )

$\mathrm{E}_{\beta} \quad$ Beta-ray transition energy; also the maximum energy or end-point energy of the spectrum of beta rays observed for a single transition

$E_{\gamma} \quad$ Transition gamma-ray energy

$E_{x} \quad$ Energy of an excited state with respect to the ground state of a particular nuclide

$\left\langle\mathrm{E}_{\beta}\right\rangle \quad$ Average energy per decay for a given beta-ray transition obtained by integration of the spectrum of $N(E)$ vs $E$, i.e.: $\int N(E) E d E$

$\left\langle\mathrm{E}_{n}\right\rangle \quad$ Average energy of spectrum of delayed neutrons obtained in a manner similar to $\left\langle\mathrm{E}_{\beta}\right\rangle$

$\mathrm{F}(\mathrm{Z}, \mathrm{W}) \quad$ Fermi function

J Level spin

$\pi \quad$ Level parity

$P_{n} \quad$ Total delayed neutron intensity as a percentage of the total radionuclide decay

$\overline{\mathrm{Q}}_{\beta} \quad$ Total energy available in beta decay

$\mathrm{S}_{n} \quad$ Shape factor for an $\mathrm{n}$-forbidden transition $(\mathrm{n}=0$ for an allowed transition)

W Response total energy in units of electron mass (electron mass $=0.511 \mathrm{MeV}$ )

Z Radionuclide proton number 


\section{RELATIONSHIP TO OTHER TABULATIONS}

There is only one evaluation of total beta-ray spectra from decay of fission products that I am aware of, and that is the multigroup (binned) spectra of individual fission products by England and Stamatelatos. $^{28}$ Beta-ray spectra for 163 fission products are tabulated for 75 response energies grouped into $0.1-\mathrm{MeV}$ bins. Values for $\mathrm{E}_{\beta}$ and $\mathrm{A}_{\beta}$ were obtained from the ENDF/B-IV evaluation. ${ }^{19}$ Although not stated explicitly in the documentation, ${ }^{28}$ the statistical shape factor is used for all calculations, resulting in calculated responses which will be somewhat at variance with calculations using correct shape factors. An example is given for the decay of ${ }^{90} \mathrm{Y}$ in Fig. 1.

Other evaluations ${ }^{16-21}$ are of the nuclear data similar to the present compilation, some including values of $\left\langle\mathrm{E}_{\beta}\right\rangle$ for nuclides lacking experimental nuclear data. The evaluations that were used include the Table of Isotopes (Seventh Edition) $)^{29}$ and data in the ENDSL data files ${ }^{30}$. for known beta-ray decay, and values of $\left\langle\mathrm{E}_{\beta}\right\rangle$ from the ENDF/B-IV evaluation ${ }^{19}$ when there was no alternate basis for determining these data.

Values of $\left\langle\mathrm{E}_{\beta}\right\rangle$ deduced from the present compilation by integrating the total computed beta-ray spectrum for thirty representative fission products having completely evaluated decay schemes are presented in Table I. Also given are values of $\left\langle\mathrm{E}_{\beta}\right\rangle$ given in the U.S. ENDF/B-IV file, ${ }^{19}$ the current U.K. UKFPDD-2 file, ${ }^{20}$ and the current Japanese JNDC file. ${ }^{21}$ The four evaluated data sets are essentially independent evaluations for the tabulated isotopes. Recent measurements ${ }^{23}$ of $\left\langle\mathrm{E}_{\beta}\right\rangle$ are given in the last column of this table. One may observe that only for ${ }^{92} \mathrm{Y},{ }^{98} \mathrm{Nb}$, and ${ }^{139} \mathrm{Cs}$ is there agreement among all four evaluated and the one experimental data set in this table. With differences indicated in this table for the evaluation of supposedly well-known decay schemes, one might expect even poorer agreement for isotopes having poorly known decay schemes. However, as shown by all of the data given in Table II for isotopes having spectral data estimated from partial information in the present file, the overall agreement is about the same as in Table I. 


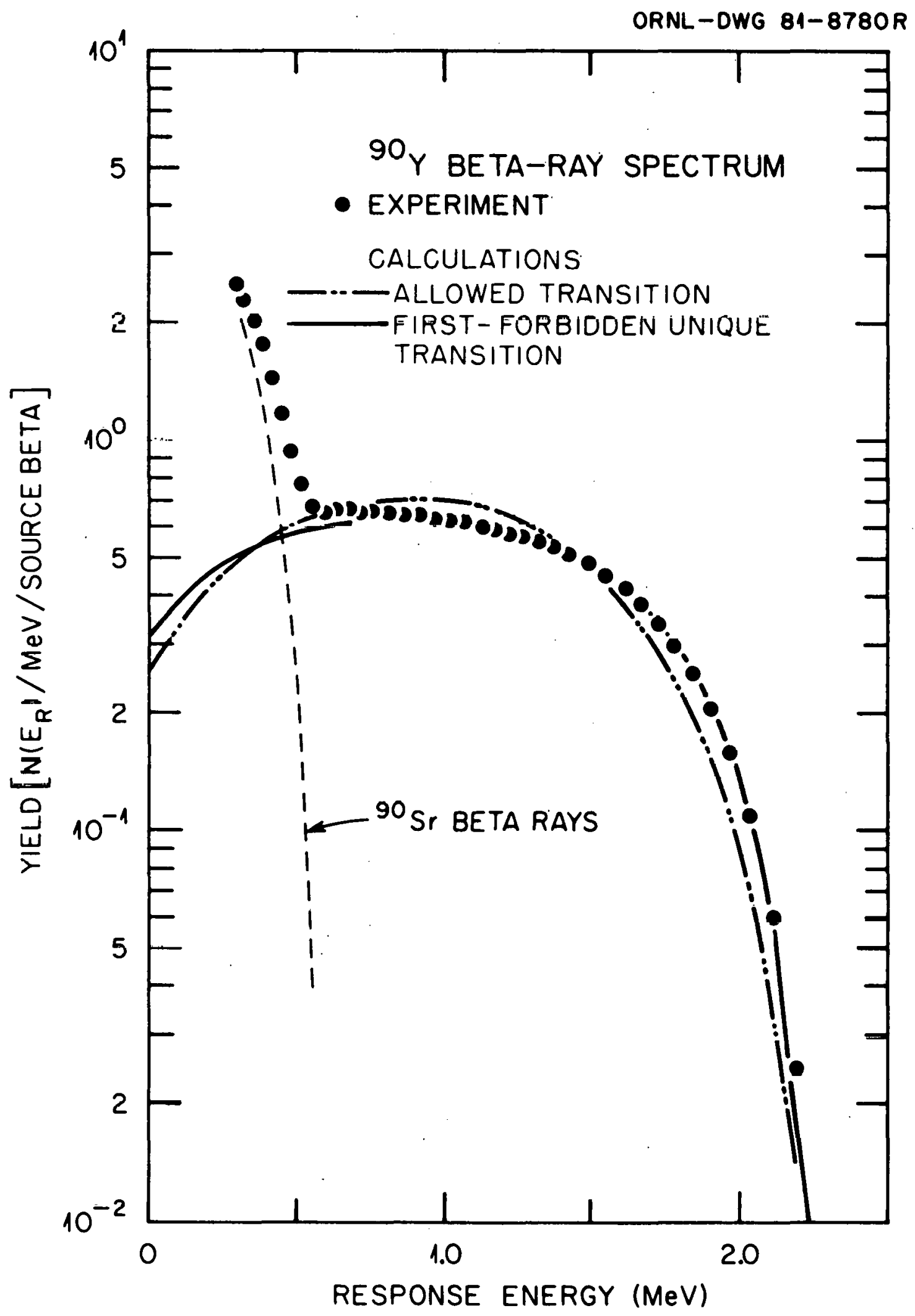

Fig. 1. ${ }^{90} \mathrm{Y}$ Beta-Ray Spectrum. Data were obtained using a scintillation detector described in ref. 2. Calculations are for two choices of shape factor $S_{1}$. The dot-dash line represents the calculation using the allowed shape and is essentially equivalent to the binned spectrum for ${ }^{90} \mathrm{Y}$ given in ref. 28. The solid line represents the calculation using the shape factor for the first-forbidden unique transition given in Eq. (2) of the text. 
Table I. Average beta-ray energies for representative fission products

\begin{tabular}{|c|c|c|c|c|c|}
\hline \multirow[b]{2}{*}{ Isotope $^{a}$} & \multicolumn{5}{|c|}{ Average beta-ray energy (MeV) } \\
\hline & $\begin{array}{c}\text { Present } \\
\text { Compilation }\end{array}$ & $\begin{array}{c}\text { ENDF/B-IV } \\
\text { (ref. 19) }\end{array}$ & $\begin{array}{l}\text { UKFPDD-2 } \\
\text { (ref. 20) }\end{array}$ & $\begin{array}{c}\text { JNDC } \\
\text { (ref. 21) }\end{array}$ & $\begin{array}{c}\text { Experiment } \\
\text { (ref.23) }\end{array}$ \\
\hline${ }^{84} \mathrm{As}$ & 4.03 & 3.76 & 4.08 & $2.83^{\circ}$ & 3.84 \\
\hline${ }^{86} \mathrm{Br}$ & 1.96 & 1.78 & 1.78 & 1.95 & 1.93 \\
\hline${ }^{88} \mathrm{Br}$ & 3.04 & 3.07 & 2.52 & 2.45 & 1.63 \\
\hline${ }^{90} \mathrm{Rb}(153 \mathrm{~s})$ & 2.35 & 1.66 & 1.86 & 1.57 & 1.36 \\
\hline${ }^{91} \mathrm{Rb}$ & 1.57 & 1.33 & 1.51 & 1.48 & 1.36 \\
\hline${ }^{91} \mathrm{Rb}$ & 3.68 & 3.46 & 3.46 & 2.86 & 3.46 \\
\hline${ }^{92} \mathrm{Y}$ & 1.50 & 1.46 & 1.44 & 1.46 & 1.46 \\
\hline${ }^{93} \mathrm{Kr}$ & 2.82 & 2.76 & 3.33 & 2.73 & 2.70 \\
\hline${ }^{94} \mathrm{Y}$ & 1.93 & 1.72 & 1.79 & 1.81 & 1.78 \\
\hline${ }^{95} \mathrm{Sr}$ & 2.32 & 1.94 & 2.26 & 1.59 & 1.92 \\
\hline${ }^{95} \mathrm{Y}$ & 1.39 & 1.75 & 1.34 & 1.37 & 1.52 \\
\hline${ }^{97} \mathrm{Sr}$ & 2.68 & 2.35 & 2.63 & 2.60 & 2.28 \\
\hline${ }^{97} \mathrm{Y}(3.3 \mathrm{~s})$ & 2.17 & & 2.16 & 2.47 & 2.05 \\
\hline${ }^{98} \mathrm{Y}(0.7 \mathrm{~s})$ & 3.28 & & 3.11 & 3.26 & 3.54 \\
\hline${ }^{98} \mathrm{Nb}(2.9 \mathrm{~s})$ & 1.99 & 1.87 & 1.97 & 1.97 & 1.97 \\
\hline${ }^{99} \mathrm{Zr}$ & 1.47 & 1.62 & 1.50 & 1.46 & 1.57 \\
\hline${ }^{101} \mathrm{Nb}$ & 1.89 & 1.90 & 1.86 & 1.69 & 1.31 \\
\hline${ }^{103} \mathrm{Tc}$ & 0.81 & 0.72 & 0.78 & 0.84 & \\
\hline${ }^{108} \mathrm{Tc}$ & 3.34 & 2.62 & 3.32 & 2.25 & 2.21 \\
\hline${ }^{128} \operatorname{In}(0.9 \mathrm{~s})$ & 2.80 & & 2.80 & 3.05 & 3.26 \\
\hline${ }^{134} \mathrm{Sb}(10 \mathrm{~s})$ & 2.90 & 2.95 & 2.91 & 2.28 & 2.38 \\
\hline${ }^{137} \mathrm{Xe}$ & 1.66 & 1.84 & 1.79 & 1.79 & 1.73 \\
\hline${ }^{138} \mathrm{I}$ & 2.72 & 2.12 & 2.81 & 3.29 & 2.27 \\
\hline${ }^{1.39} \mathrm{Xe}$ & 1.71 & 1.79 & 1.74 & 1.00 & 1.72 \\
\hline${ }^{139} \mathrm{rs}$ & 1.72 & 1.76 & 1.70 & 1.70 & 1.73 \\
\hline${ }^{140} \mathrm{Cs}$ & $1.59^{\circ}$ & 1.93 & 1.74 & 1.43 & 1.89 \\
\hline${ }^{141} \mathrm{Cs}$ & 1.81 & 1.38 & 1.79 & 1.28 & 1.68 \\
\hline${ }^{143} \mathrm{Ba}$ & 1.78 & 1.09 & 1.65 & 1.70 & 1.26 \\
\hline${ }^{143} \mathrm{La}$ & 1.36 & 0.84 & 1.33 & 1.34 & 1.21 \\
\hline${ }^{144} \mathrm{La}$ & 1.58 & 1.51 & 1.47 & 1.34 & 0.98 \\
\hline
\end{tabular}

${ }^{a}$ Isomer designated by lifetime in parenthesis. 
Table II. Average beta-ray energies for fission products represented by estimated spectral data in the present compilation

\begin{tabular}{lccccc}
\hline & \multicolumn{5}{c}{ Average beta-ray energy (MeV) } \\
\cline { 2 - 6 } \multicolumn{1}{c}{ Isotope ${ }^{a}$} & $\begin{array}{c}\text { Present } \\
\text { Compilation }\end{array}$ & $\begin{array}{c}\text { ENDF/B-IV } \\
\text { (ref. 19) }\end{array}$ & $\begin{array}{c}\text { UKFPDD-2 } \\
\text { (ref. 20) }\end{array}$ & $\begin{array}{c}\text { JNDC } \\
\text { (ref. 21) }\end{array}$ & $\begin{array}{c}\text { Experiment } \\
\text { (ref. 23) }\end{array}$ \\
\hline${ }^{83} \mathrm{As}$ & 1.09 & 1.68 & 1.08 & 2.00 & 1.86 \\
${ }^{85} \mathrm{As}$ & 2.43 & 2.87 & $\mathrm{~b}$ & 2.84 & 3.32 \\
${ }^{90} \mathrm{Br}$ & 2.92 & 3.36 & $\mathrm{~b}$ & 3.09 & 3.52 \\
${ }^{100} \mathrm{Nb}(3.1 \mathrm{~s})$ & 2.01 & 2.10 & 2.12 & 1.76 & 1.63 \\
${ }^{102} \mathrm{Nb}(4.3 \mathrm{~s})$ & 2.23 & 2.48 & 2.49 & 2.83 & 1.93 \\
& & & & & \\
${ }^{113} \mathrm{Pd}$ & 1.43 & 1.06 & $\mathrm{~b}$ & 1.45 & \\
${ }^{126} \mathrm{Cd}$ & 1.74 & 1.28 & 1.70 & 1.99 & 1.39 \\
${ }^{129} \mathrm{Sn}(498 \mathrm{~s})$ & 1.35 & 1.15 & $\mathrm{~b}$ & 1.18 & 1.24 \\
${ }^{131} \mathrm{~S}$ II $(50 \mathrm{~s})$ & 1.40 & 1.31 & $\mathrm{~b}$ & & 1.47 \\
${ }^{132} \mathrm{In}$ & 3.77 & 3.83 & $\mathrm{~b}$ & .3 .16 & 3.28 \\
& & & & & \\
${ }^{133} \mathrm{Sb}$ & 0.63 & 0.54 & $0.67^{c}$ & 0.75 & \\
${ }^{135} \mathrm{Sb}$ & 2.23 & 2.06 & $\mathrm{~b}$ & 2.48 & 2.39 \\
${ }^{144} \mathrm{Cs}$ & 3.19 & 2.35 & $3.08^{c}$ & $: 2.65$ & 2.24 \\
${ }^{152} \mathrm{Pm}(450 \mathrm{~S})$ & 0.86 & 0.42 & $0.90^{c}$ & 0.86 & \\
${ }^{137} \mathrm{Sm}$ & 0.91 & 0.55 & $0.90^{c}$ & 0.89 & \\
\hline
\end{tabular}

${ }^{a}$ Isomer designated by lifetime in parenthesis.

"Taken from EINEF/B.IV.

${ }^{c}$ Report indicates spectral data were determined. 
The comparisons of the data given in these tables are meant only to indicate the present status of evaluation and experiment. For the present goal of providing beta-ray spectra, the present compilation is easy to use and readily amenable to rapid updating, and is shown to provide beta-ray spectra which, when weighted by fission-product yields and summed, reproduce ${ }^{27,31}$ rather well total beta-ray spectra ${ }^{1,2}$ from fission of ${ }^{235} \mathrm{U}$ discussed in the Introduction.

\section{UNCERTAINTIES AND INACCURACIES}

Uncertainties and inaccuracies associated with the basic nuclear data include $\Delta \mathrm{Q}_{\beta}, \Delta \mathrm{A}_{\beta}$, and $\Delta \mathrm{E}_{\beta}$ (partly as a function of $\mathrm{Q}_{\beta}$ ) and incorrect shape-parameter assignments. All of these will affect the resulting calculated total beta-ray spectrum in a similar manner however. The most sensitive part of the spectrum is for response energies $\mathrm{E}$ close to the end-point energy, e.g., E $>2 \mathrm{MeV}$ in Fig. 1, where errors of a factor of 2 can occur as a result of a very nominal error in a nuclear data parameter. The least sensitive portion of the spectrum is for $\mathrm{E} \sim 0.5 \mathrm{E}_{\beta}$, e.g., $\sim 1 \mathrm{MeV}$ in Fig. 1. Experience shows that in this energy region the largest variances relate to incorrect shape parameters and are generally $<15 \%$. For complex decay schemes, various sets of $\dot{A}_{\beta}$ within given $\Delta \mathrm{A}_{\beta}$, and subject to the restriction $\Sigma \mathrm{A}_{\rho}=100 \%$, result in essentially indistinguishable computed beta-ray spectra, except for the largest response energies.

No unccrtainties are given in the present compilation for three reasons. The first. as alluded to in the previous paragraph, is that there is no direct method of relating an uncertainty at a given energy in the total beta-ray response to a given uncertainty in an input parameter. About the only method to determine changes in total response is to repeat the computation with a different set of parameters. The second reason is that there are large correlations among the various parameters, and it would be necessary to review each experiment to deduce the "best" complete variance-covariance matrix. The third reason is that the major "error" in most of the total response computation is likely due to the use of the allowed shape in lieu of any information to the contrary. If, however, these uncertainties could

- be correctly combined, the inaccuracies to an overall calculated total beta-ray spectrum would be comparable to uncertainties associated with current experimental techniques. 


\section{DISCUSSION OF THE COMPUTER PROGRAM AND TABULAR DATA}

\section{Mathematical Aspects}

The computer program (see Appendix for listing) was developed to compute the electron spectrum for an $n$-times forbidden transition; the basic equation for the number of beta rays at a given response energy $(E)$ can bc written as: $:^{32,33}$

$$
N(W) d W=K F(Z, W) p W\left(W_{o}-W\right)^{2} S_{n}(W) d W
$$

where $W=1+E / m^{2} ; W_{o}$ corresponds to the maximum energy beta, $E_{\beta} ; F(Z, W)$ is the Fermi function which is important for all but the lightest elements; $p$ is the $\beta$-ray mementum; and $S_{n}$ is the shape factor. $\mathrm{K}$ is a constant, treated here as a normalizing parameter. For Allowed transitions, characterized by $\Delta \mathrm{J}=0,1$ and $\Delta \pi=\pi_{i} \pi_{f}=+1$, to first order $\mathrm{S}_{o}(\mathrm{~W})=1.0$. Small deviations from unity have been reported (see the tabulation of Behrens and Szybisz). ${ }^{26}$ For Allowed transitions in the present report $S_{o}(W)=1.0$ for all $W$.

Transitions for which $n \geqslant 1$ are Forbidden transitions and are generally associated with either more energetic transitions or with longer half lives than usually found for allowed transitions. $S_{n}$ has an analytic expression for Unique Forbidden transitions which are characterized by $\Delta \mathrm{J}=\mathrm{n}+1$ and $\Delta \pi=$ $(-1)^{n}$. For these cases the shape factors are $\mathrm{e}^{33,34}$

$$
\begin{aligned}
& S_{1}=\left(W^{2}-1\right)+\left(W_{o}-W\right)^{2} \\
& S_{2}^{\prime}=\left(W^{2}-1\right)^{2}+\left(W_{o}-W\right)^{4}+3.33\left(\tilde{W}^{2}-1\right)\left(W_{o}-W\right)^{2} \\
& S_{3}=\left(W^{2}-1\right)^{3}+\left(W_{n}-W\right)^{6}+7\left(W^{2}-1\right)\left(W_{o}-W\right)^{2}\left[\left(W^{2}-1\right)+\left(W_{u}-W\right)^{2}\right]
\end{aligned}
$$

Non-unique Forbidden transitions are characterized by $\Delta \mathrm{J}=\mathrm{n}$ (also $\Delta \mathrm{J}=0$ for $\mathrm{n}=1$ ) and $\Delta \pi=(-1)^{n}$. For $n=1$ and $2, S_{n}$ has the forms ${ }^{33}$ 


$$
\begin{aligned}
& S_{1}=a_{o}+a_{1} W+a_{2} W+a_{3} W^{2}, \\
& S_{2}=\left(W_{o}-W\right)^{2}+a_{1}\left(W^{2}-1\right)
\end{aligned}
$$

and the $a_{i}$ coefficients have to be determined from the experimental beta-ray spectrum.

The Fermi function takes into account the Coulomb force on the electron. Treating the electron nonrelativistically, an approximate expression is obtained ${ }^{35}$ for $F(Z, E)$ :

$$
F_{o}(Z, E)=\frac{2 \pi X}{1-\exp (-X)}
$$

where $X=Z^{2} / h v$ for electrons, $v$ being the speed of the electron far away and $Z$ the atomic number of the daughter (product) nucleus. This expression is satisfactory (to $\pm 3 \%$ ) for $Z<30$ and electron energies a few $\mathrm{MeV}$ or less. A more generally useful approximation ${ }^{36}$ can be written as

$$
F(Z, E)=F_{o}(Z, E) \quad\left[\frac{W^{2}\left(1+0.000852 Z^{2}\right)-1}{4}\right]^{Y}
$$

where

$$
Y=\left(1-0.0000533 Z^{2}\right)^{1 / 2}-1
$$

This approximation is satisfactory (to $\pm 2 \%$ ) for $L<\%$.

\section{The Computer Program}

The subroutine BETASP and related subprograms are utilized to read up to eleven records of information from the file of data, and from these to compute both a beta-ray and an antineutrino spectrum. Variables required at entry are

$$
\begin{aligned}
& \mathrm{IZ}=\text { Radionuclide proton number, integer, } \\
& \mathrm{IA}=\text { Isotope mass, integer, and } \\
& \mathrm{DE}=\text { Response energy bin width in MeV. }
\end{aligned}
$$


At exit, the spectral data will be returned as follows:

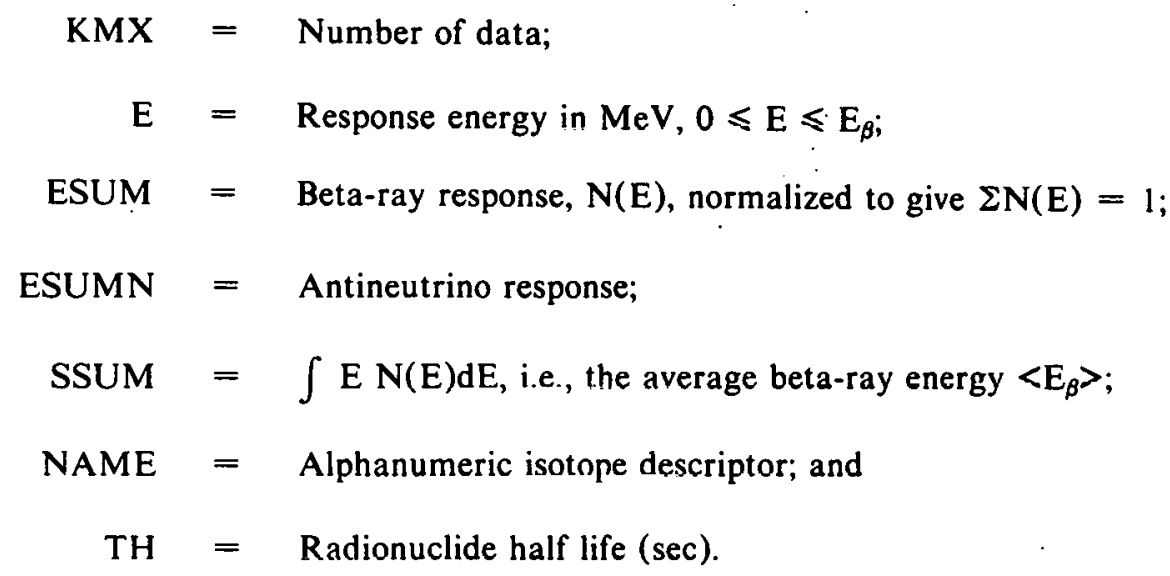

After reading the appropriate data records for input IZ and IA, the program calculates the total response, including forbidden shapes for up to $3^{d}$-forbidden unique and up to $2^{d}$-forbidden non-unique if known parameters are included in the data table. The results are in number-per-bin-width.

An exact calculation of number-per-bin-width would require numerical integration of (1), viz.

$$
\int_{E-0.5 D E}^{E+0.5 D E} N(W) d W
$$

However, in the present routine DE is assumed small enough to treat $N(W)$ as a constant value for the $D E(d W=D E)$ interval of interest.

As mentioned above, fọ a radionuclide having only an average energy $\left\langle\mathrm{E}_{\beta}\right\rangle$ entered in the data table, the program assumes that the $\left\langle\mathrm{E}_{\beta}\right\rangle$ entry corresponds to the average energy of a single, allowed transition. There is also a provision in the program to include conversion electron contributions to be summed to the beta-ray spectral data. At present, there are entries in the data file for conversion electron contributions from decay of $>50$ fission products.

\section{The Data File}

For a given radionuclide the file contains the following data: (a) the first record, in (3I5, A5, F10.3) format, contains, 


$$
\begin{aligned}
\mathrm{IZ} & =\text { isotope proton number, } \\
\mathrm{IA} & =\text { isotope mass, } \\
\mathrm{NB} & =\text { number of beta-ray transitions }(\leqslant 10), \\
\text { NAME } & =\text { alphanumeric descriptor, and } \\
\mathrm{T} & =\text { half life in seconds. }
\end{aligned}
$$

If the $\mathrm{IZ}$ is input as $400+$ proton number, the information is for a fission product designated as an isomer. (Comments included in the physical record are ignored during calculations.)

The second and, if needed, subsequent records, in (I5, 5F8.3) format, contain

$$
\begin{aligned}
\mathrm{NF} & =\text { degress of forbiddness, } \\
\text { EMAX } & =\text { transition energy }(\mathrm{MeV}) \text {, i.e., the maximum beta-ray energy or the beta-ray end point, } \\
\mathrm{B} & =\text { absolute transition probability, } \mathrm{A}_{\beta} \text {, in percent, and } \\
\mathrm{C}_{1,2,3} & =\text { shape coefficients, the } \mathrm{a}_{i} \text { Eq. }(5)\left[\mathrm{a}_{o}=1.0 \text { assumed }\right] \text { if known. }
\end{aligned}
$$

Allowed transitions are designated by $N F=0$, unique $n$-forbidden by $N F=+n$, non-unique $n$ forbidden by $N F=-n$. For a few entries $N F=-5$ for conversion electrons having $E_{c e}=E M A X$. If EMAX is negative, then $\mathrm{EMAX}=\left\langle\mathrm{E}_{\beta}\right\rangle$, an average beta-ray energy, gotten either from experimental data, ${ }^{23}$, or from analysis ${ }^{25}$ of data used to obtain ${ }^{37}$ strength functions, or else from estimations given in the Evaluated Nuclear Data File, ${ }^{19}$ ENDF/B-IV. Essentially all entries are (cryptically) referenced; the full references follow the table and are from the reviewed literature available to January 1982.

\section{DISCUSSION AND RECOMMENDATION}

The purpose of this compilation is to provide the means of determining beta-ray spectra to an accuracy comparable to that expected from experimental beta-ray measurements. Nearly all of the spectroscopic data in the data file have been obtained from or made use of existing evaluations of nuclear data, or have been obtained from recent reports of experimental measurements. There are, in addition, about 
30 radionuclides for which spectroscopic data were estimated from fragmentary experimental information (e.g., delayed-neutron yields, partial gamma-ray decay schemes). For these nuclides, some of which are listed in Table II, the estimated data are expected to provide a better calculated total betaray spectrum than would be given by any other method of determining a total beta-ray spectrum.

The strongest recommendation is for a resurgence in interest in measuring individual beta-ray spectra, especially to small response energies, E. In particular, the question of possible inaccurate and/or incomplete decay schemes being deduced from gamma-ray measurements, suggested in refs. 23 to 25 , requires attention.

The data given in the main "Data Table" are available from the Radiation Shielding and Information Center of the Oak Ridge National Laboratory upon request.

\section{ACKNOWLEDGEMENTS}

The efforts of D. M. Hetrick and S. R. Damewood for computer checking and manuscript preparation are greatly appreciated. 


\section{REFERENCES}

1. K. Schreckenbach, H. R. Faust, F. von Feilitzsch, A. A. Hahn, K. Hawerkamp and J. L. Vuilleumier, Phys. Lett. 99B, 25 (1981).

2. J. K. Dickens, T. A. Love, J. W. McConnell, and R. W. Peelle, Nucl. Sci. Eng. 74, 106 (1980). J. K. Dickens, T. A. Love, J. W. McConnell, J. F. Emery, K. J. Northcutt, R. W. Peelle, and H. Weaver, "Delayed Beta- and Gamma-Ray Production Due to Thermal-Neutron Fission of ${ }^{235} \mathrm{U}$, Spectral Distributions for Times After Fission Between 2 and 14000 sec; Tabular and Graphical Data," ORNL/NUREG-39 (1978). Spectral data are available from the ORNL Radiation Shielding Information Center (RSIC) upon request.

3. J. K. Dickens, T. R. England, T. A. Love, J. W. McConnell; J. F. Emery, K. J. Northcutt, and R. W. Peelle, "Delayed Beta- and Gamma-Ray Production Due to Thermal-Neutron Fission of ${ }^{239} \mathrm{Pu}$ : Tabular and Graphical Spectral Distributions for Times After Fission Between 2 and 14000 sec," ORNL/NUREG-66 (1980).

4. J. K. Dickens, J. F. Emery, T. A. Love, J. W. McConnell, K. J. Northcutt, R. W. Peelle, and H. Weaver, "Fission-Product Energy Release for Times Following Thermal-Neutron Fission of ${ }^{241} \mathrm{Pu}$ Between 2 and 14000 Seconds," ORNL/NUREG-47 (1978).

5. F. Reines, H. W. Sobel, and E. Pasierb, Phys. Rev. Lett. 45, 1307 (1980).

6. F. Boehm, J. F. Cavaignac, F. von Feilitzsch, A. A. Hahn, H. E. Henrikson, D. H. Koang, H. Kwon, R. L. Mossbauer, B. Vignon, and J. L. Vuilleumier, Phys. Lett. 97 B, 310 (1980).

7. T. R. England, R. Wilczynski, and N. L. Whittemore, "CINDER-7: An Interim Report for Users," LA-5885-MS (1975).

8. M. J. Bell, "ORIGEN - The ORNL Isotope Generation and Depletion Code," ORNL-4628 (1973). 
9. C. Deviller, B. Nimal, C. Fiche, J. P. Noel, J. Blachot, and R. de Tourreil, "Sensitivity of the Afterheat from ${ }^{235} \mathrm{U}$ and ${ }^{239} \mathrm{Pu}$ Thermal Fission to Errors in Fission Product Nuclear Data," Proc. Conf. Nucl. Cross Sections and Technology, Washington, D.C., March 3-5, 1975, NBS Special Publication 425, CONF-750303, I, 29, U.S. National Bureau of Standards (1975).

10. A. Tobias, J. Nucl. Energy 27, 725 (1973); see also, A. Tobias, "FISP5 - An Extended and Improved Version of the Fission Product Inventory Code FISP," RD/B/N4303, U.K. Central Electricity Generating Board, Berkeley (1978).

11. B. I. Spinrad, "The ROPEY System," in "Evaluation of Fission Product Afterheat, Annual Report 75-76," NUREG-0018-4, pp. 4.8-4.11 and Appendix D, Oregon State University (1977).

12. D. R. Marr, "A User's Manual for Computer Code RIBD-II, A Fission Product Inventory Code," HEDL-TME-75-26 (1975).

13. G. Rudstam, J. Radioanal. Chem. 55, 79 (1980).

14. T. Yamamoto and K. Sugiyama, "Summation Calculations of Fission-Product Decay Heat, Their Uncertainties and Their Applications to a Fast Breeder Reactor," NETU-22, Tohoku University, Japan (1977).

15. P. Vogel, G. K. Schenter, F. M. Mann and R. E. Schenter, Phys. Rev. C 24, 1543 (1981).

16. T. R. England and R. E. Schenter, "ENDF/B-IV Fission-Product Files: Summary of Major Nuclide Data," LA-6116-MS (1975).

17. "Nuclear Decay Data for Selected Radionuclides," ed. M. J. Martin, ORNL-5114 (1976).

18. D. C. Kocher, "Radioactive Decay Data Tables A Handbook of Decay Data for Application to Radiation Dosimetry and Radiological Assessment," DOE/TIC-11026 (1981). D. C: Kocher, "Nuclear Decay Data for Radionuclides Occurring in Routine Releases from Nuclear Fuel Cycle Facilities," ORNL/NUREG/TM-102 (1977). 
19. P. F. Rose and T. W. Burrows, "ENDF/B Fission Product Decay Data," BNL-NCS-50545, Vols. I and II (1976). [Note: ENDF/B-V was not used in the present compilation.]

20. A. Tobias and B. S. J. Davies, "UKFPDD-2: A Revised Fission Product Decay Data File in ENDF/B-IV Format," Central Electricity Generating Report No. RD/B/N4942 (1980).

21. H. Ihara, Z. Matumoto, K. Tasaka, M. Akiyama, T. Yoshida, and R. Nakasima, "JNDC FP Decay and Yield Data," JAERI-M9715, [NEANDC(J)-76/U, INDC(JAP)-63/L] (1981).

22. J. K. Dickens, T. A. Love, J. W. McConnell, and R. W. Peelle, Nucl. Sci. Eng. 78, 126 (1981).

23. K. Aleklett and G. Rudstam, Nucl. Sci. Eng. 80, 74 (1982) report $\left\langle\mathrm{E}_{\beta}\right\rangle$ for 185 fission products which were deduced from (unreported) total beta-ray spectral measurements.

24. J. C. Hardy, L. C. Carraz, B. Jonson, and P. G. Hansen, Phys. Lett. 71 B, 307 (1977).

25. C. W. Reich and R. L. Bunting, "The Use of Data from $\beta$-Strength Function Experiments to Calculate Average $\beta$ - and $\gamma$-Decay Energies," IAEA Report No. INDC (NDS)-87/GO+Sp (1978), p. 245, and Nucl. Sci. Eng. (submitted).

26. H. Behrens and L. Szybisz, "Shapes of Bela Spectra," Zentralstclle fur AtomkernenergieDokumentation Report No. ZAED 6-1 (1976).

2\%. J. K. Dickens, Phys. Rev. Lett. 46, 1061 (1981). See footnote 14 of this reference.

28. T. R. England and M. G. Stamatelatos, "Multigroup Beta and Gamma Spectra of Individual ENDF/B-IV Fission Product Nuclides, LA-NUREG-6622-MS (1976); M. G. Stamatelatos and T. R. England, "FPDCYS and FPSPEC: Computer Programs for Calculating Fission-Product Beta and Gamma Multigroup Spectra from ENDF/B-IV Data," LA-NUREG-6818-MS (1977).

29. Table of Isotopes, 7th edition, eds. C. M. Lederer and V. S. Shirley, John Wiley, New York, 1978.

30. Nuclear Data Project, Brookhaven National Laboratory. This file contains data evaluated and reported in the Nuclear Data Sheets (NDS). In the present compilation the individual NDS evaluations are referenced. Some of these data are reported in refs. 17 and 18. 
31. J. K. Dickens, Phys. Lett. B 113B, 201 (1982). The reported computations were performed with the present data updated through April 1981. Additions since then have been for fission products having small fission yields.

32. E. Konopinski, p. 291 in Beta-and Gamma-Ray Spectroscopy, ed. K. Siegbahn, Interscience, New York, 1955.

33. H. Daniel, Rev. Mod. Phys. 40, 659 (1968).

34. C. S. Wu, p. 1365 in Alpha-, Beta-, and Gamma-Ray Spectroscopy, Vol. 2, ed. K. Siegbahn, North-Holland, Amsteidàii, 1965.

35. J. M. Blatt and V. F. Weisskophf, p. 680 in Theoretical Nuclear Physics, John Wiley \& Sons, New York, 1952.

36. I. Feister, Phys. Rev. 78, 375 (1950).

37. K. Aleklett, G. Nyman, and G. Rudstam, Nucl. Phys. A246, 425 (1975). 


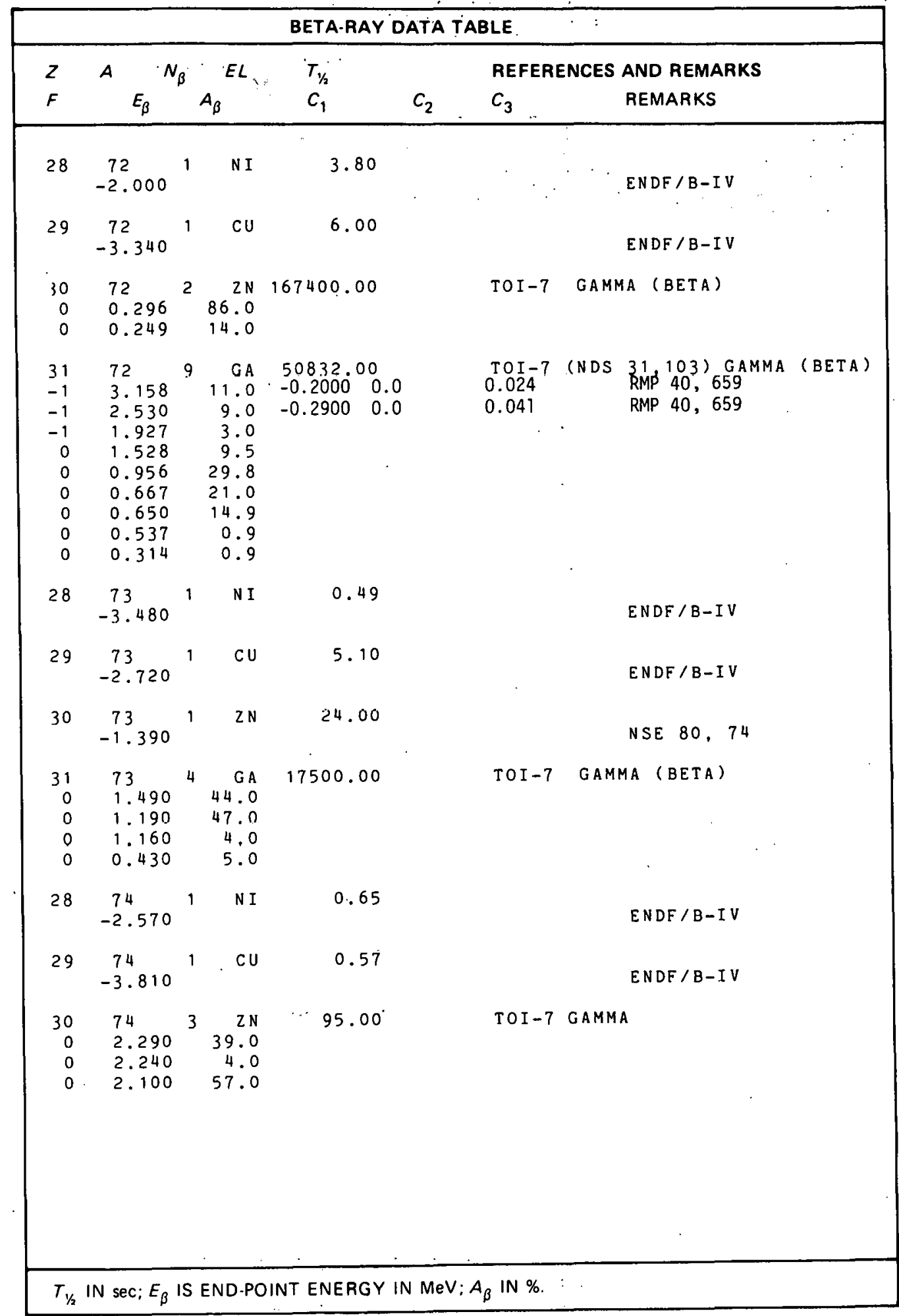

TX-5142

(7.13 82) 


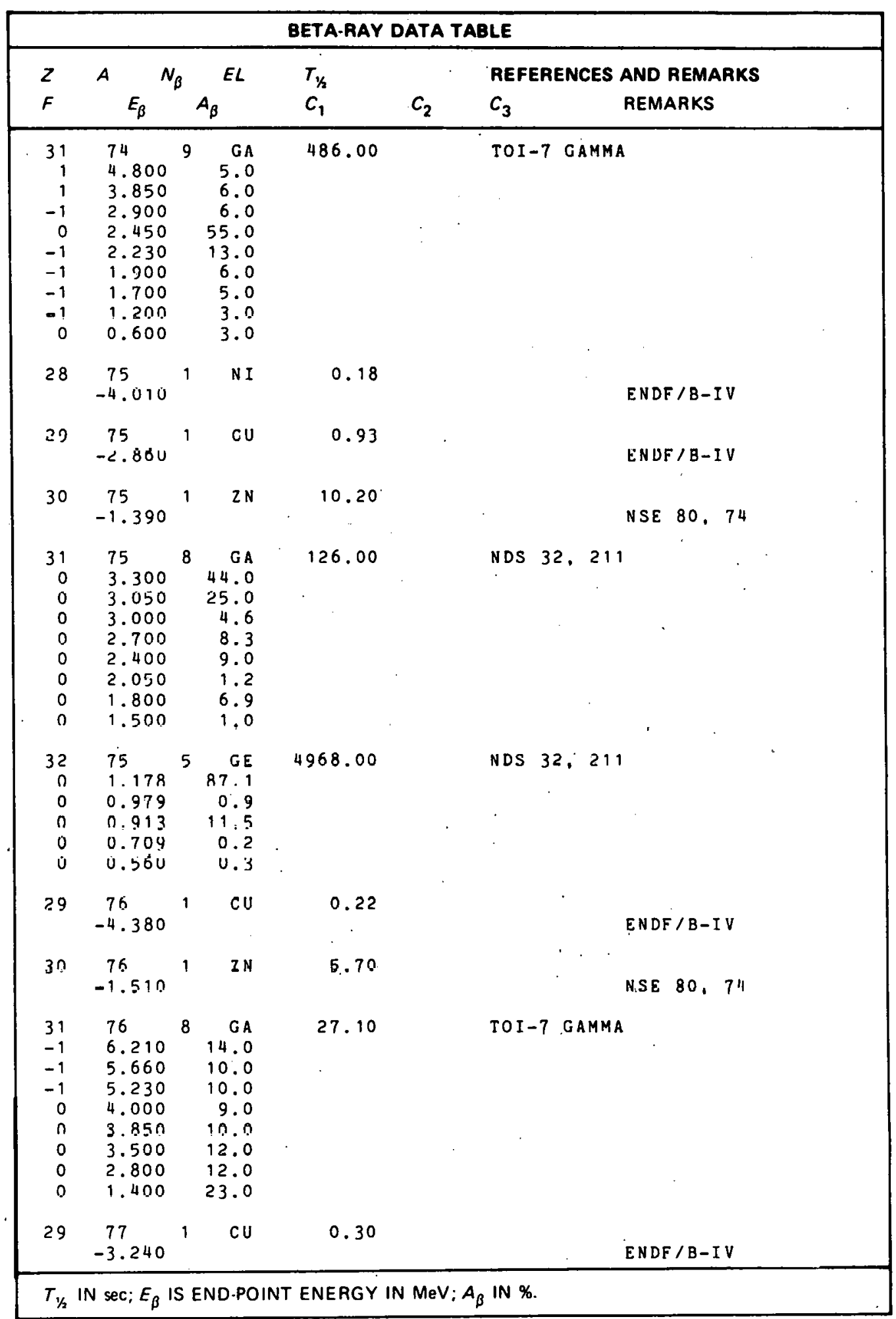

$T X-5142$

(7-13-82) 


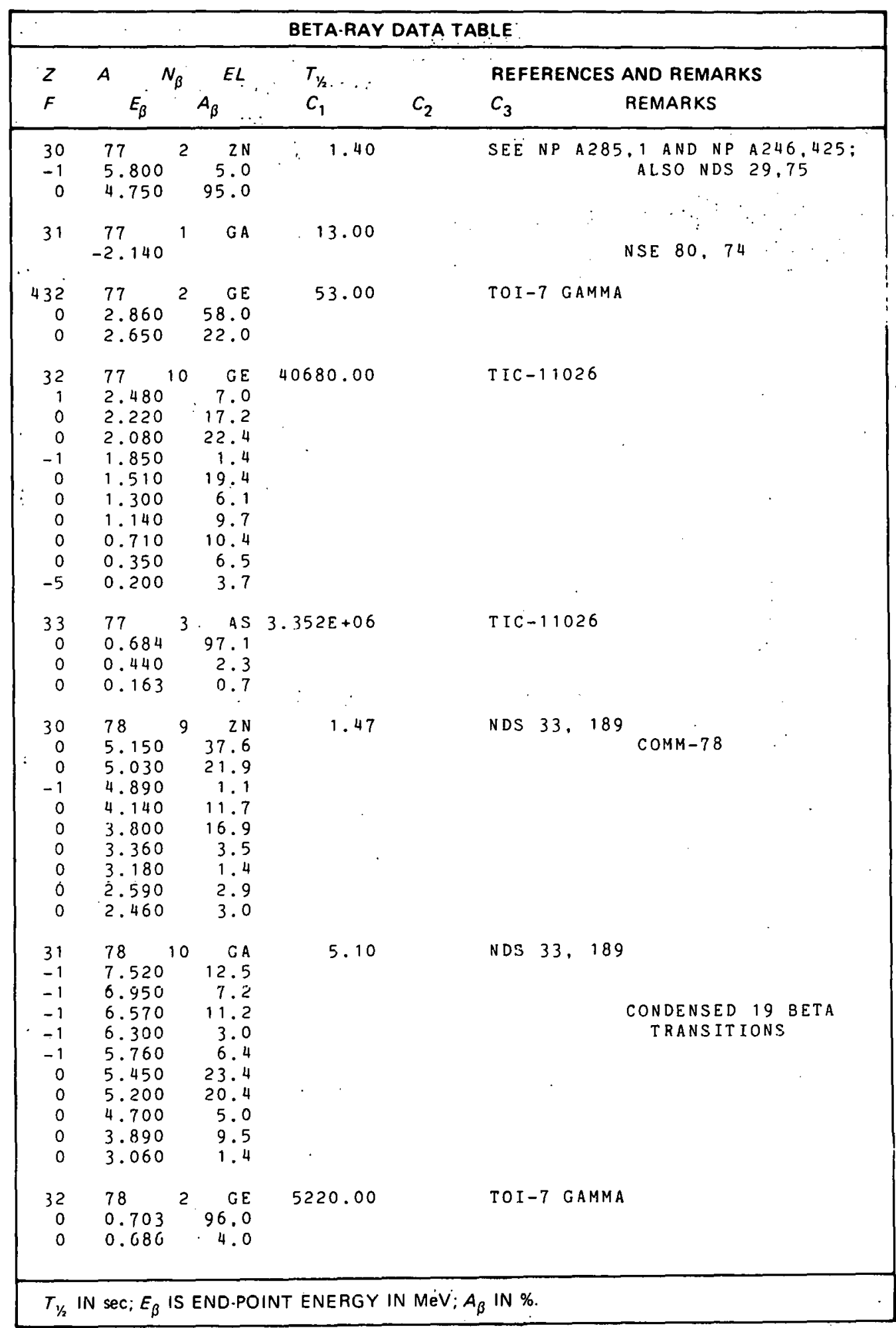

TX-5142

(7-13-82) 


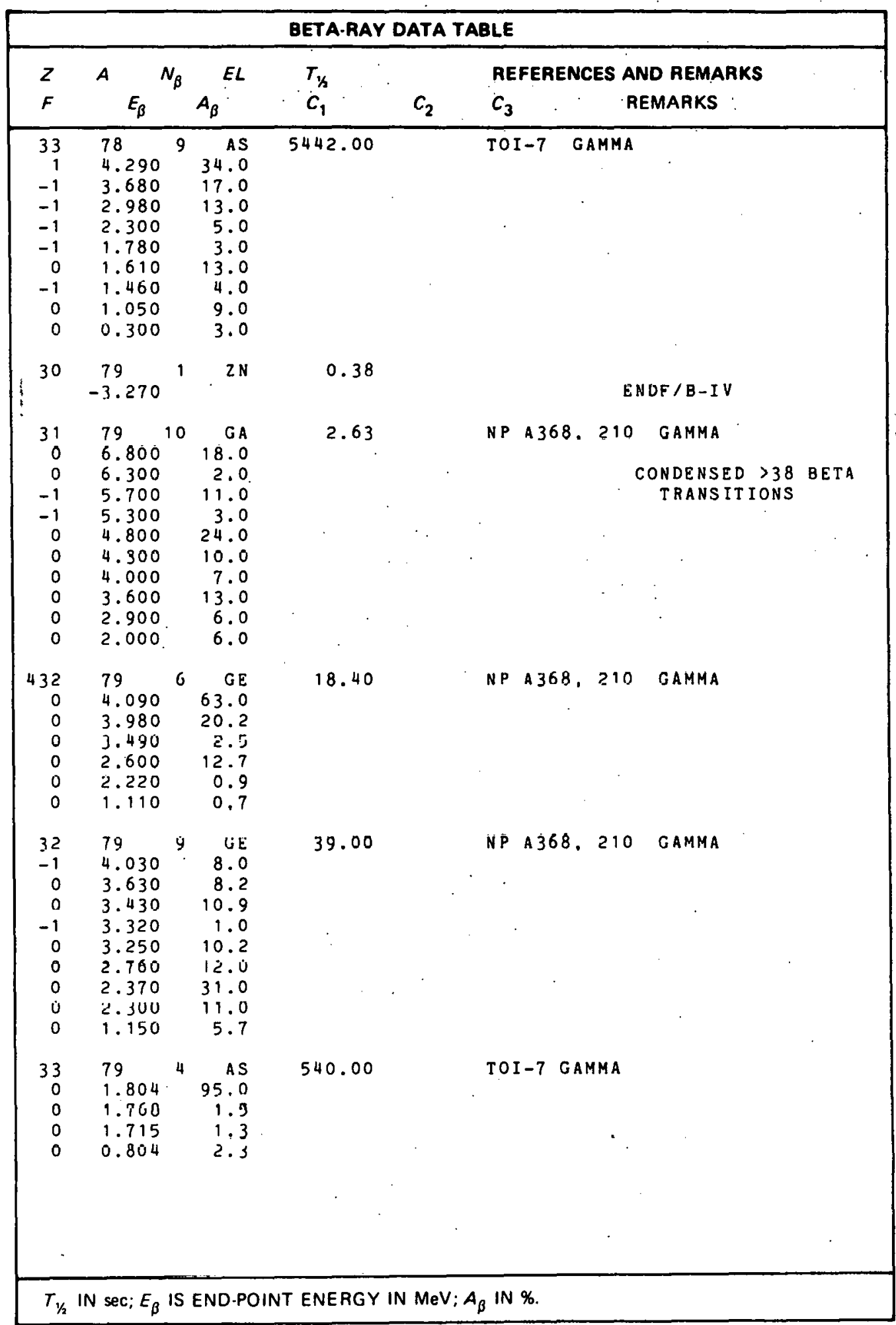

TX -5142

(7-13-82) 
23

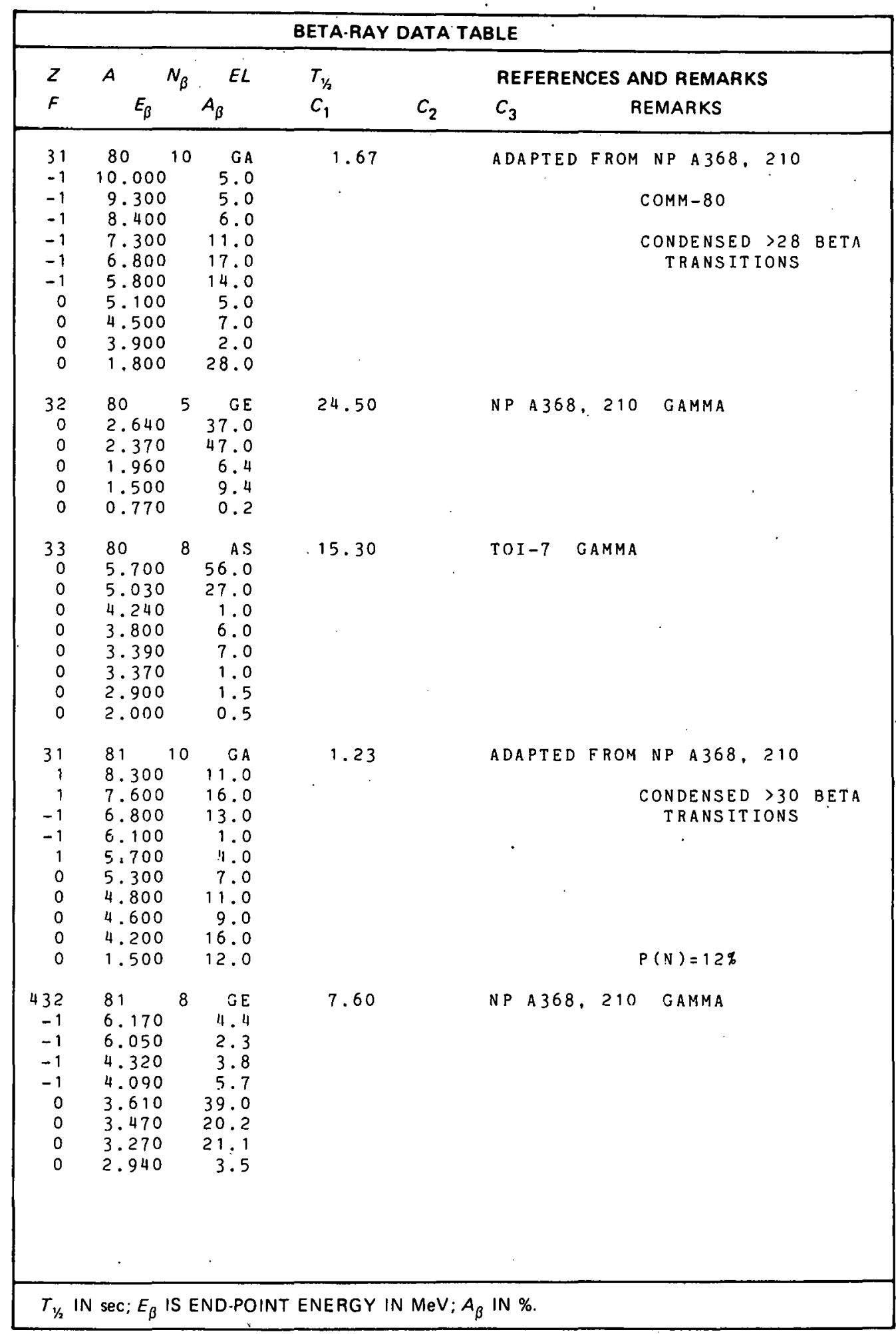

$T X-5142$

$(7-13-82)$ 


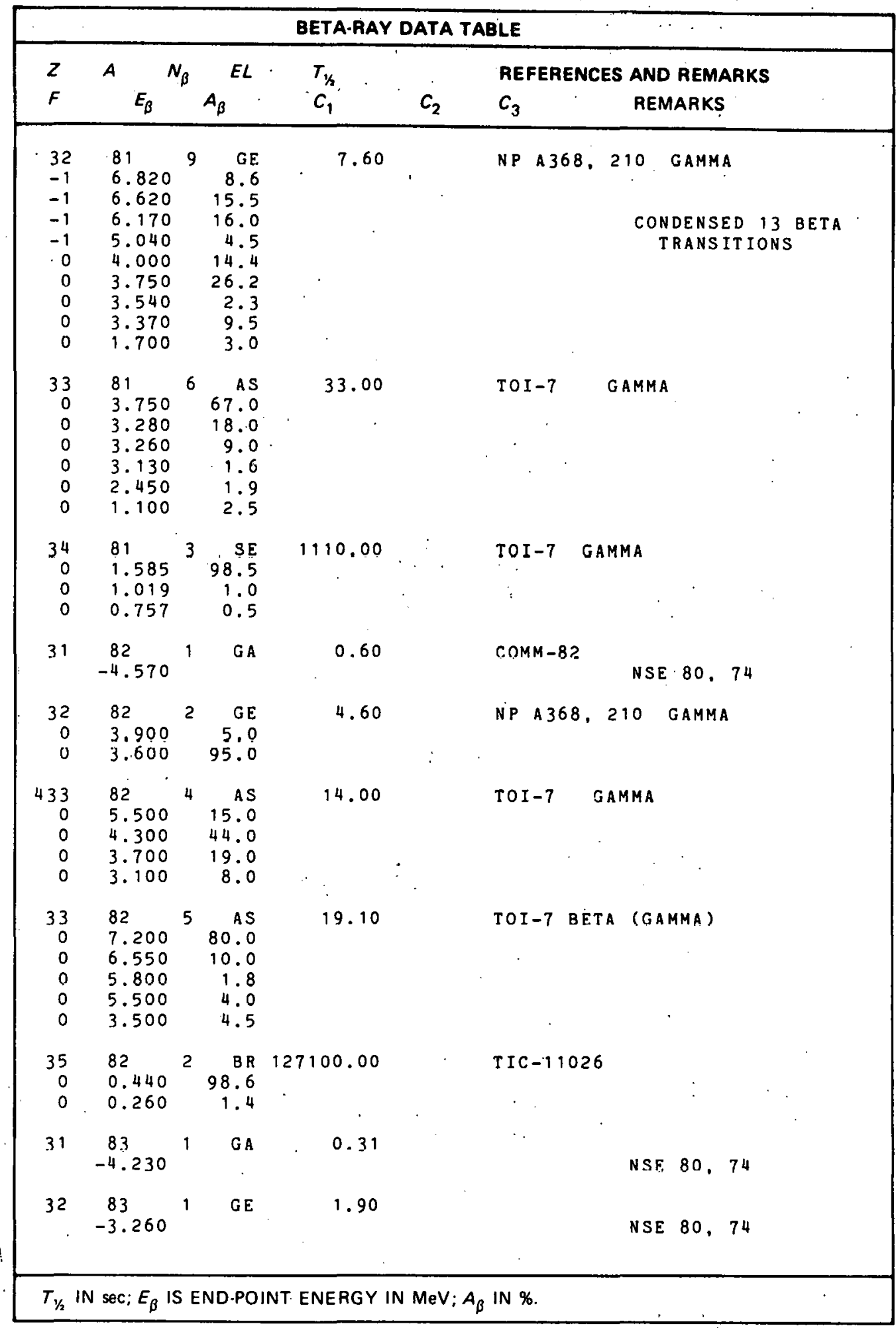

TX -5$] 42$

(7-13-82) 


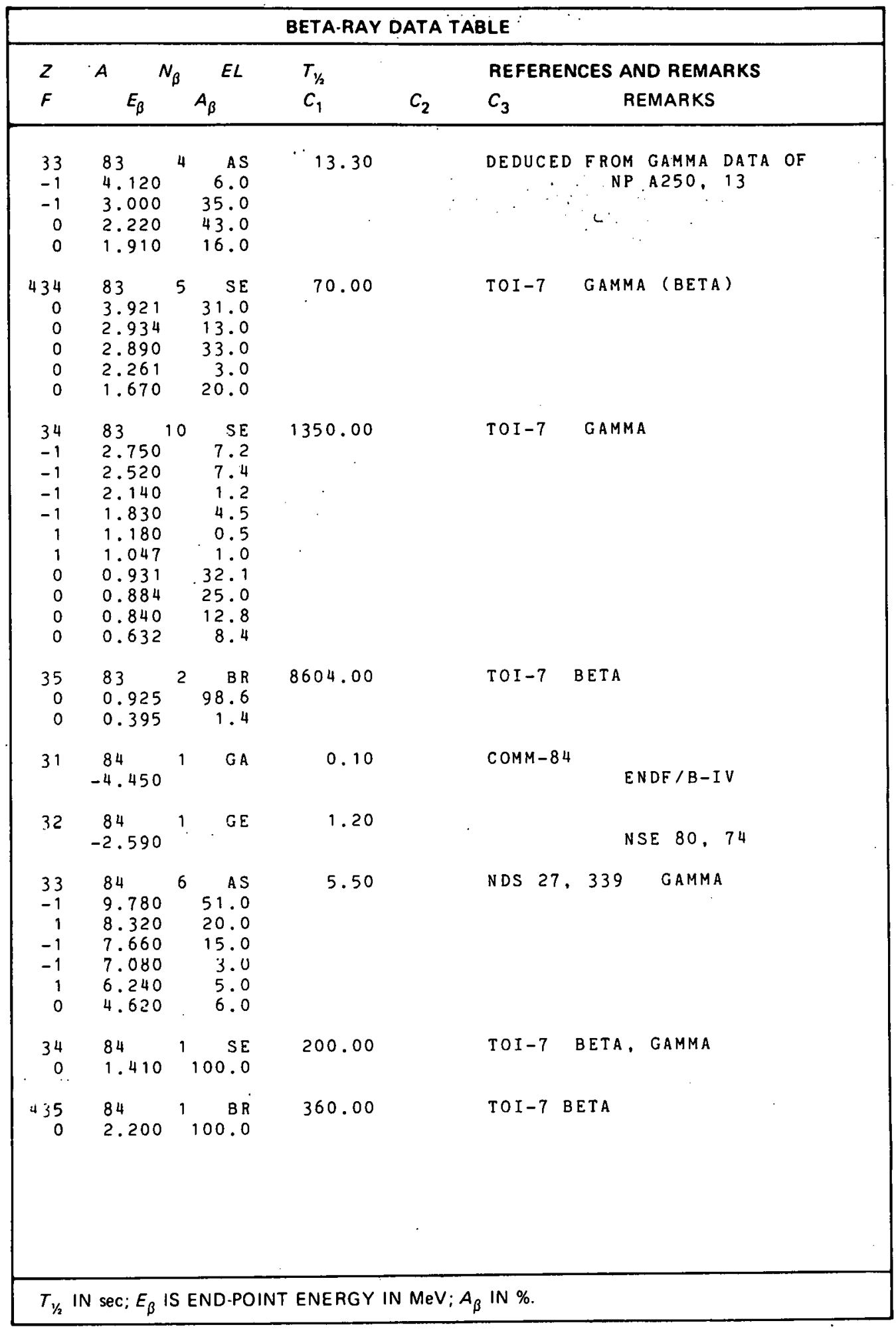

TX-5142

(7. 13-82) 


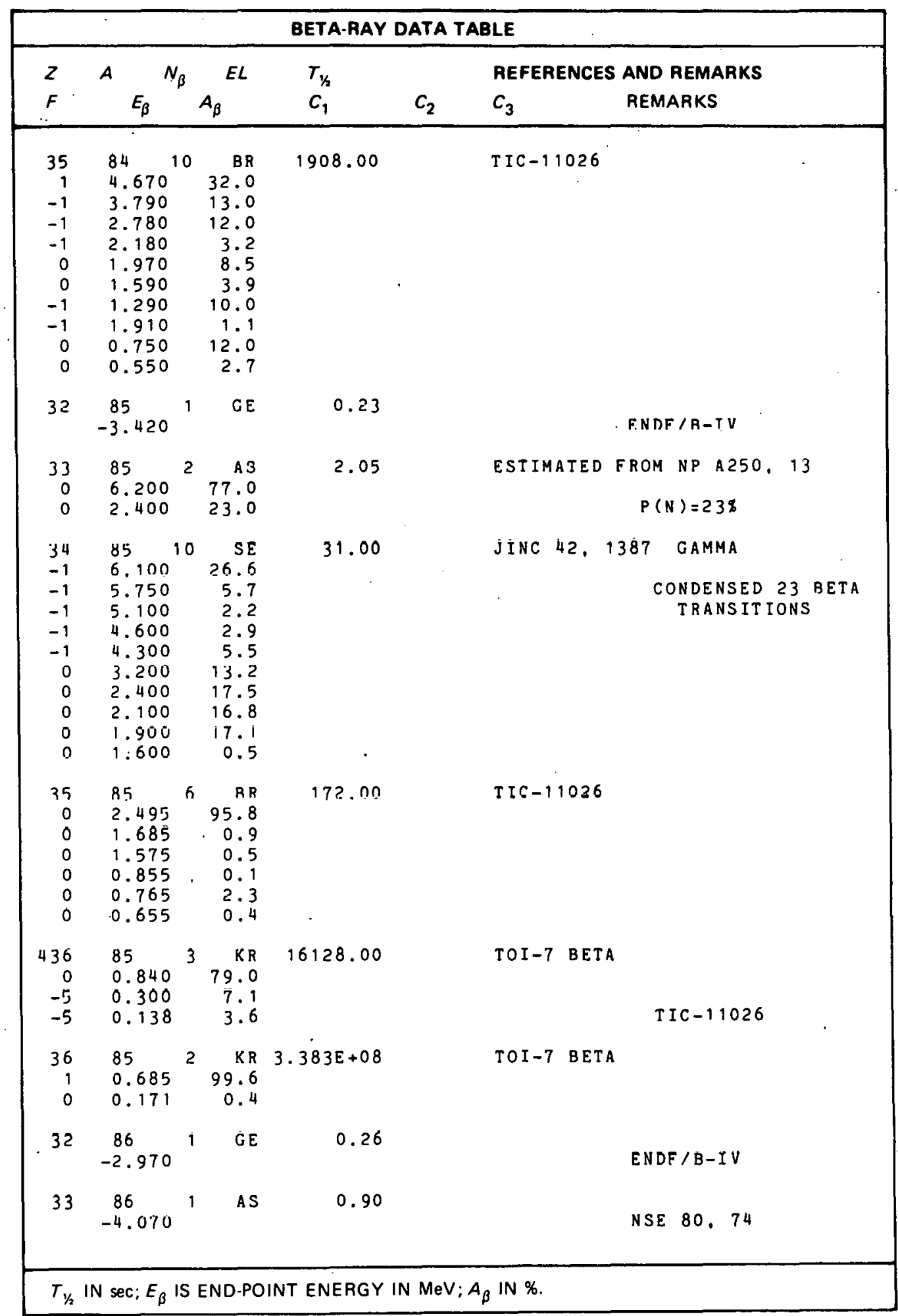




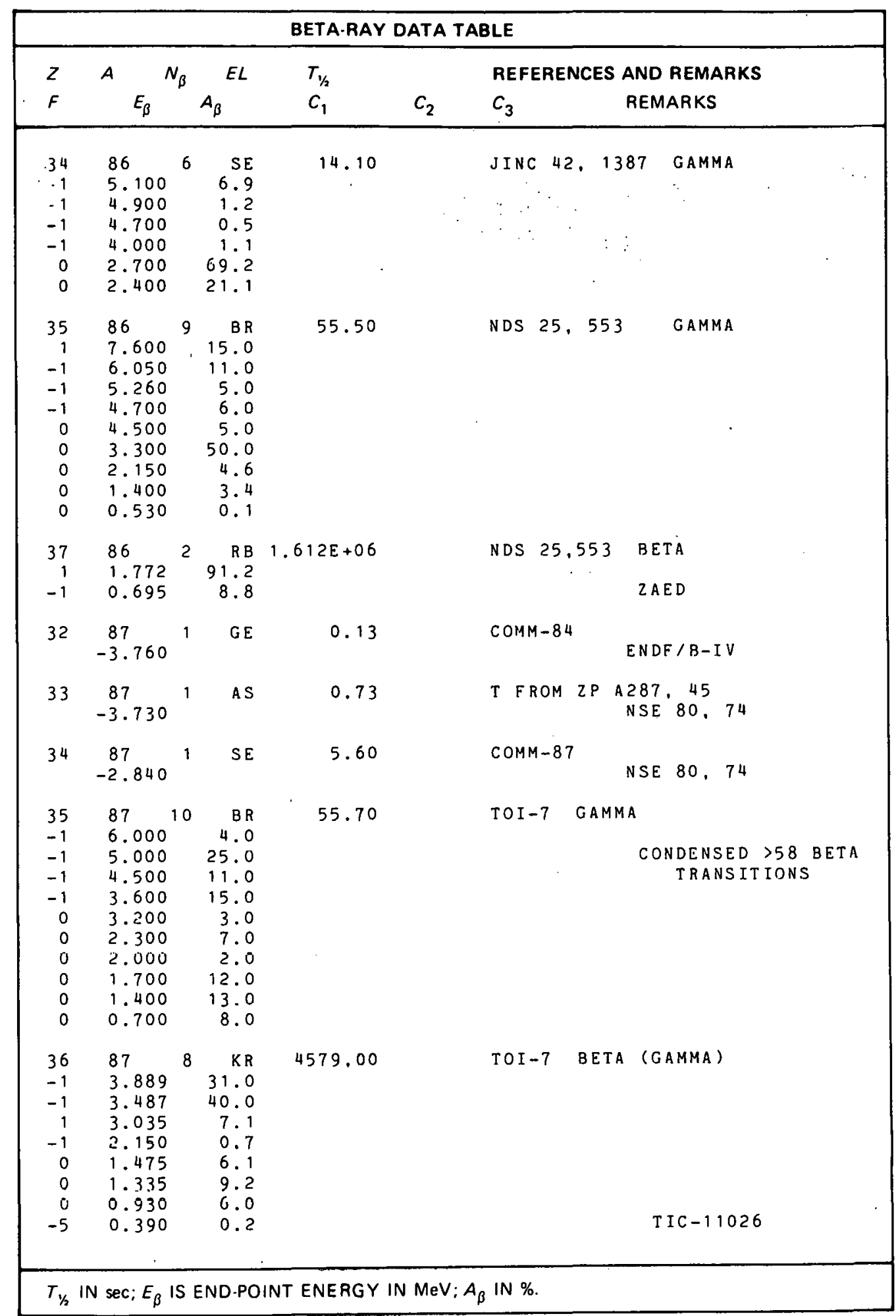

TX-5142

(7-13-82) 


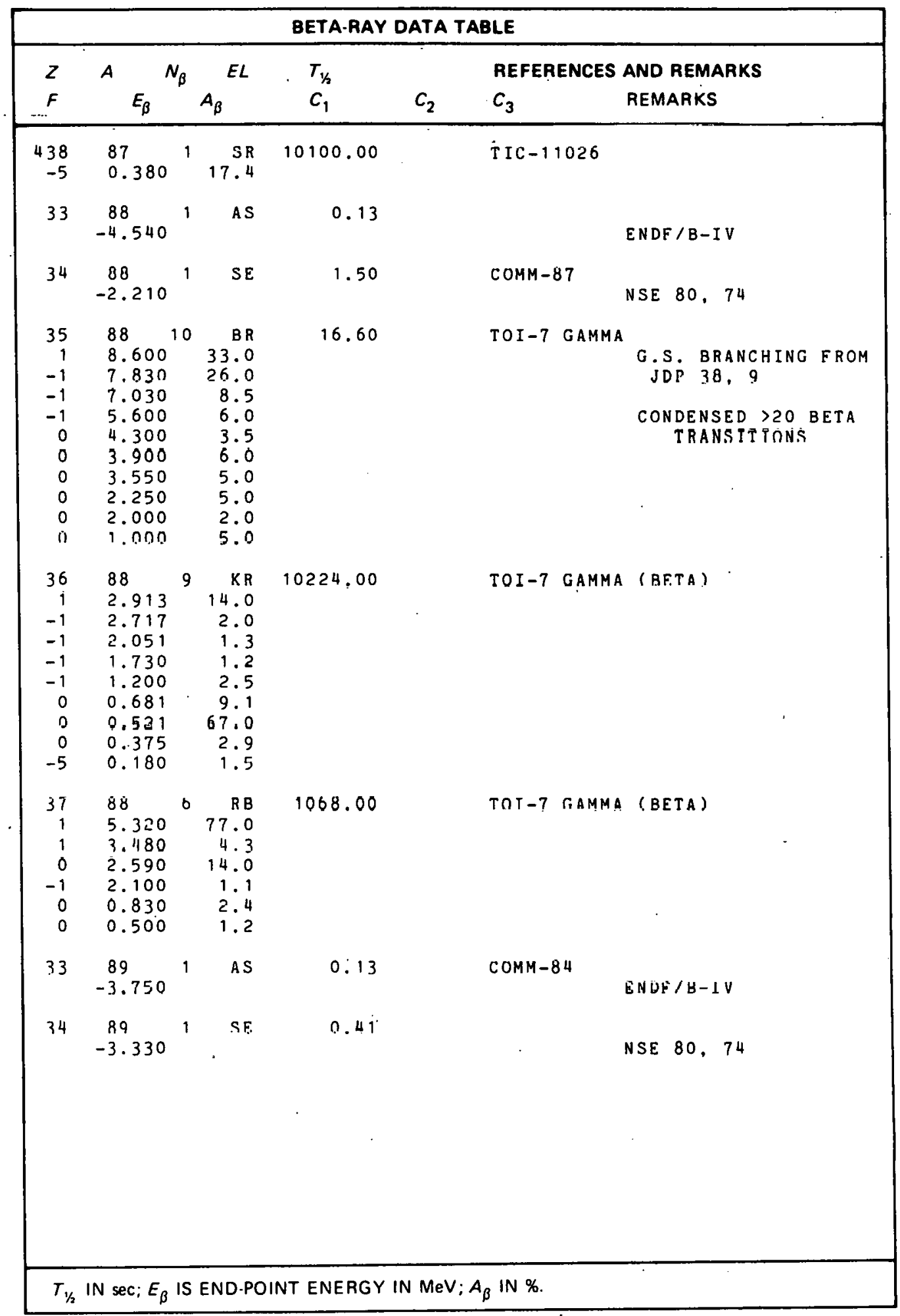




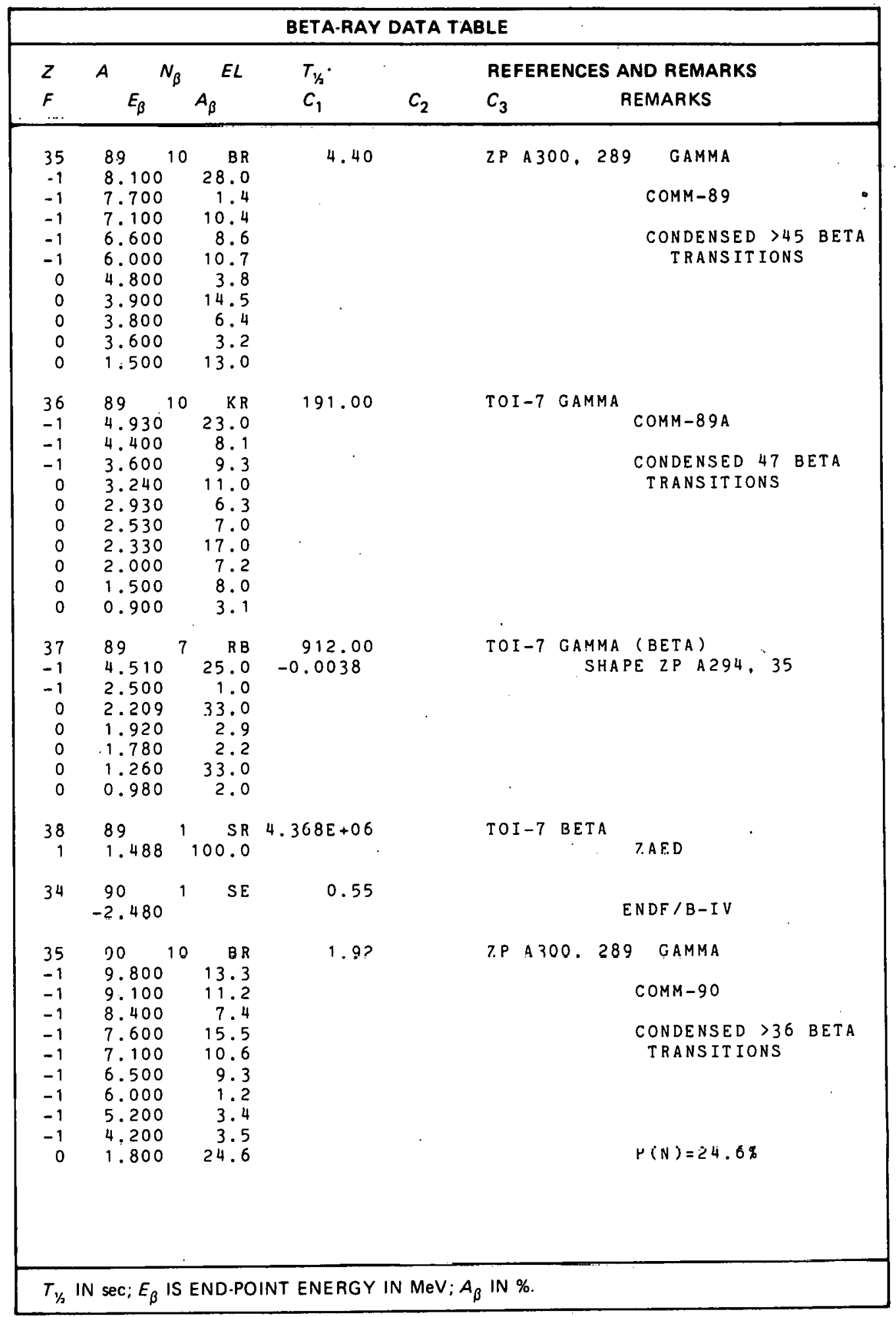

TX-5142

$(7-1.3-82)$ 


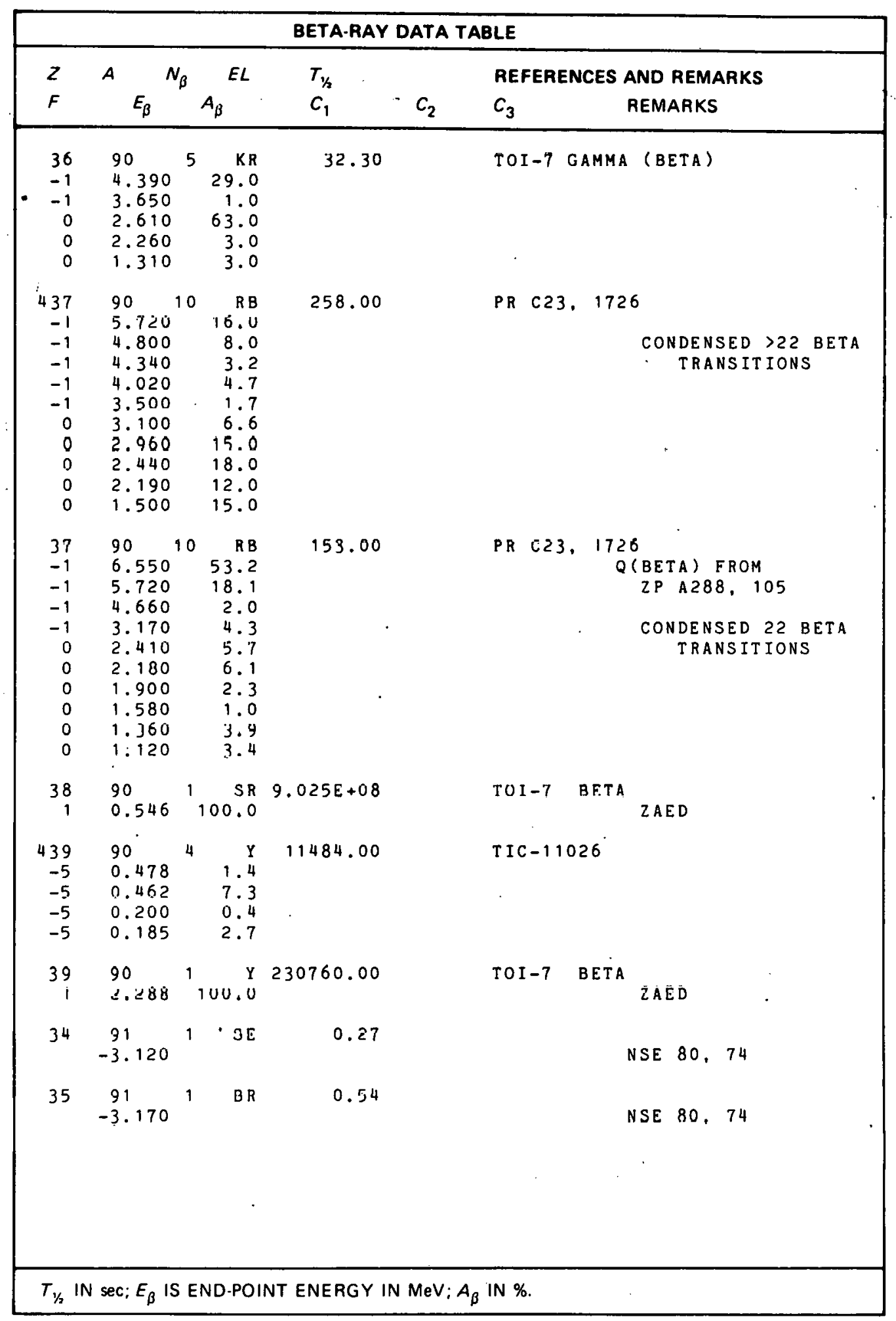

$T X-5142$

(7-13-82) 


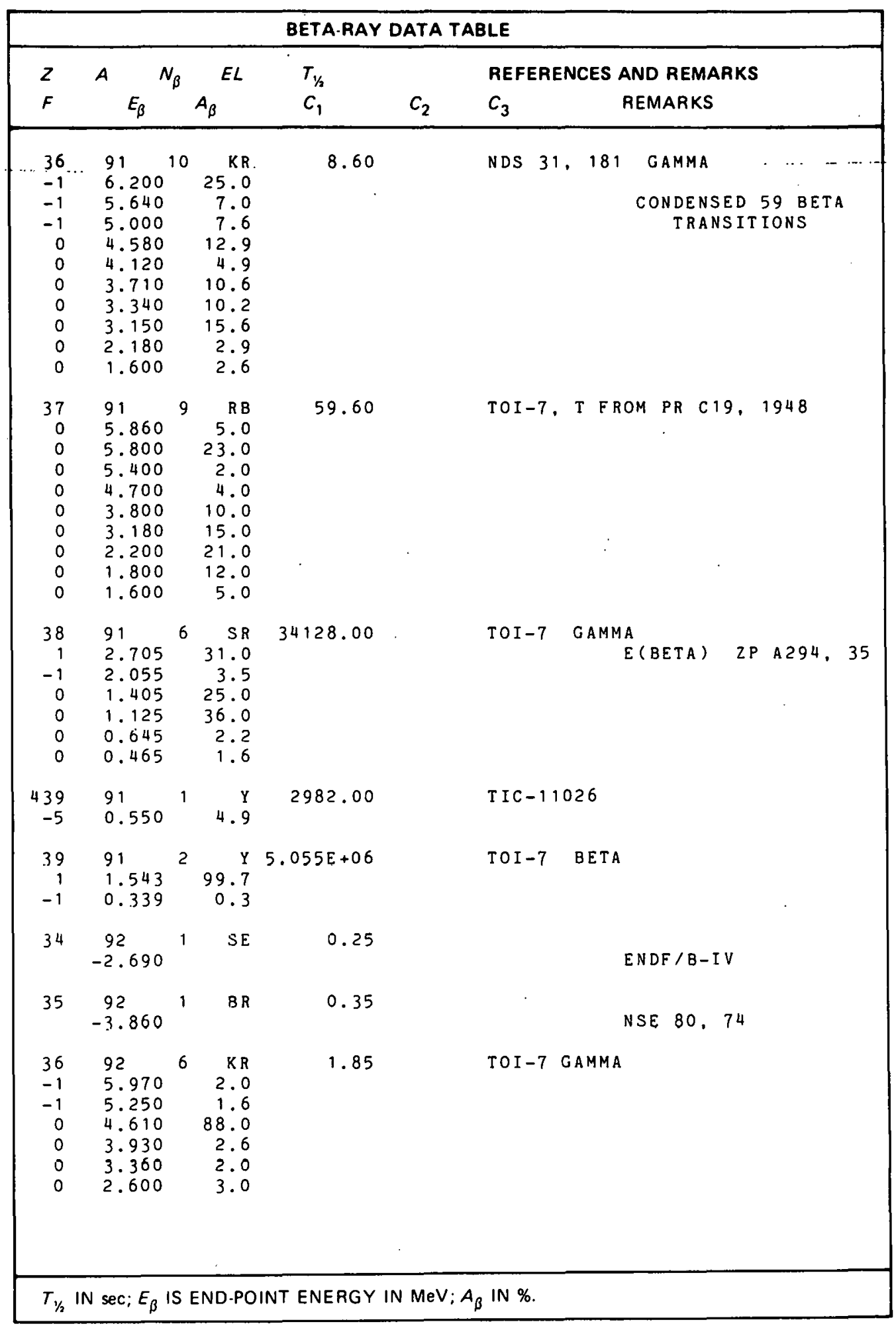

TX-5142

(7-13-82) 


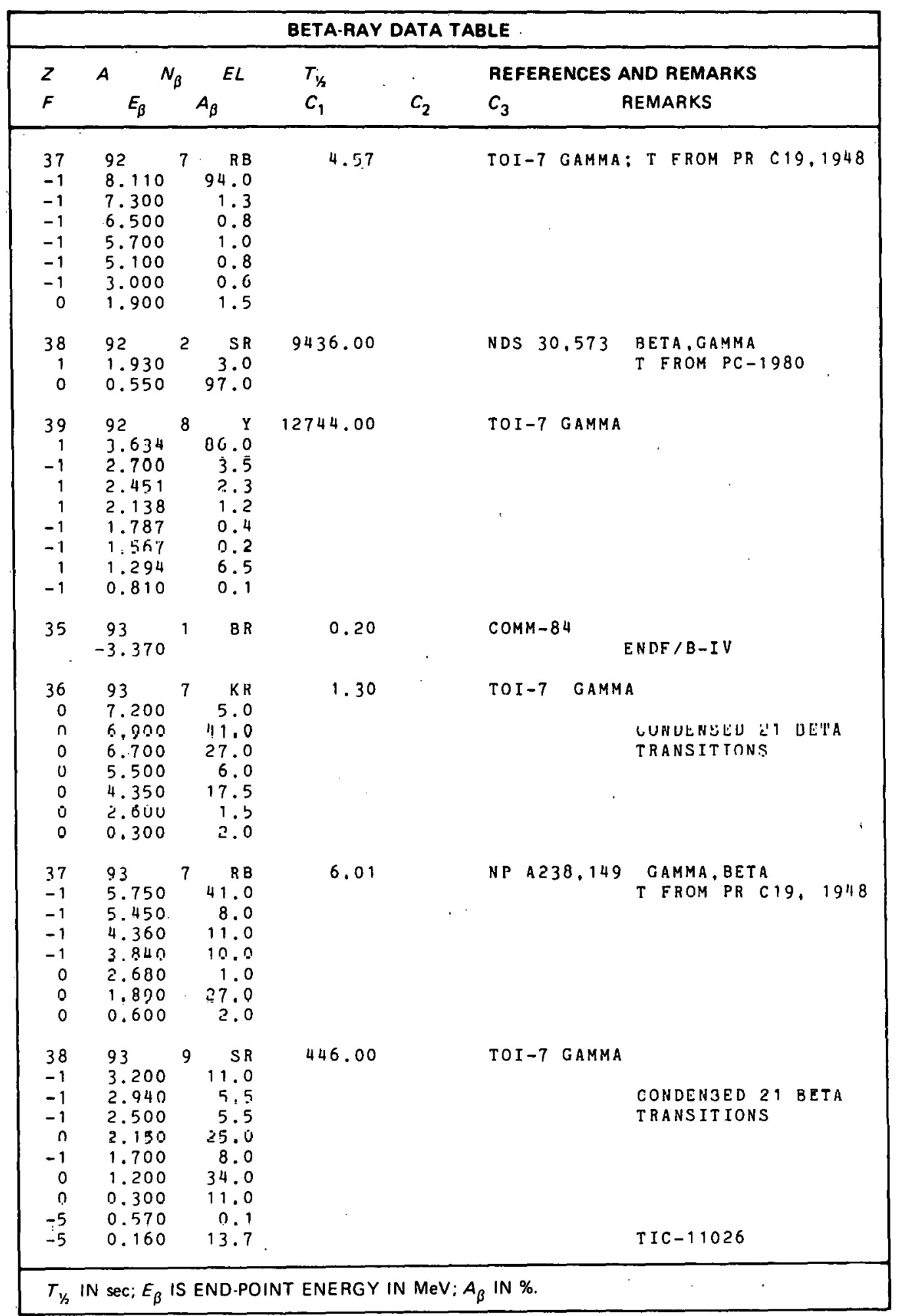

TX-5142

(7-13-82) 


\begin{tabular}{|c|c|c|c|c|}
\hline \multicolumn{5}{|c|}{ BETA-RAY DATA TABLE } \\
\hline$z$ & $A$ & $E L$ & $T_{1 / 2}$ & REFERENCES AND REMARKS \\
\hline $\boldsymbol{F}$ & $E_{\beta}$ & $A_{\dot{\beta}}$ & $c_{2}$ & REMARKS \\
\hline $\begin{array}{r}439 \\
-5\end{array}$ & $\begin{array}{l}93 \\
0.160\end{array}$ & $\begin{array}{rr}1 & Y \\
& 42.0\end{array}$ & 0.82 & TOI -7 \\
\hline $\begin{array}{r}39 \\
1 \\
-1 \\
-1 \\
-1 \\
-1 \\
-5\end{array}$ & $\begin{array}{l}93 \\
2.850 \\
2.580 \\
1.900 \\
1.400 \\
0.670 \\
0.250\end{array}$ & $\begin{array}{r}6 \\
90.0 \\
5.0 \\
2.0 \\
1.0 \\
2.0 \\
0.2\end{array}$ & 36900.00 & $\begin{aligned} \text { TOI-7 GAMMA, BETA } \\
\text { TIC }-11026\end{aligned}$ \\
\hline $\begin{array}{l}40 \\
-1\end{array}$ & $\begin{array}{l}93 \\
0.062\end{array}$ & $\begin{array}{r}1 \quad \mathrm{ZR} \\
100.0\end{array}$ & $4.830 E+13$ & T IC -1.1026 \\
\hline 35 & $\begin{array}{l}94 \\
-4.570\end{array}$ & 1 & 0.11 & ENDF/B-IV \\
\hline 36 & $\begin{array}{l}9.4 \\
-2.060\end{array}$ & 1 & 0.21 & NSE 80,74 \\
\hline $\begin{array}{r}37 \\
-1 \\
-1 \\
0 \\
0 \\
0\end{array}$ & $\begin{array}{l}94 \\
7.900 \\
7.200 \\
5.000 \\
4.000 \\
3.000\end{array}$ & $\begin{array}{r}5 \mathrm{RB} \\
15.0 \\
4.7 \\
70.6 \\
7.2 \\
2.5\end{array}$ & 2.73 & COMM-94A \\
\hline $\begin{array}{c}38 \\
0\end{array}$ & $\begin{array}{l}94 \\
2.085\end{array}$ & $\begin{array}{r}1 \quad S R \\
100.0\end{array}$ & 76.70 & $Q(B E T A) \quad Z P A 294,35$ \\
\hline $\begin{array}{r}39 \\
/ 1 \\
-1 \\
1 \\
1 \\
-1 \\
0 \\
0 \\
0\end{array}$ & $\begin{array}{l}94 \\
4.920 \\
4.000 \\
3.620 \\
3.450 \\
3.250 \\
2.820 \\
1.820 \\
0.800\end{array}$ & $\begin{array}{r}8 \quad Y \\
54.0 \\
31.0 \\
1.5 \\
3.2 \\
2.4 \\
4.1 \\
2.5 \\
1.3\end{array}$ & 1122.00 & $\begin{array}{l}\text { Q(BETA) ZPA } 294,35 \\
\text { CONDENSED >20 BETA } \\
\text { TRANSITIONS }\end{array}$ \\
\hline $\begin{array}{l}41 \\
-2 \\
-5\end{array}$ & $\begin{array}{l}94 \\
0.470 \\
0.680\end{array}$ & $\begin{array}{r}2 \quad N B \\
100.0 \\
0.2\end{array}$ & $\begin{array}{c}6.406 E+11 \\
0.5700\end{array}$ & T IC -11026 \\
\hline 35 & $\begin{array}{l}95 \\
-3.120\end{array}$ & BR & 0.11 & ENDF / B-IV \\
\hline 36 & $\begin{array}{l}95 \\
-3.160\end{array}$ & $1 \quad \mathrm{KR}$ & 0.50 & ENDF / B-IV \\
\hline $\begin{array}{r}37 \\
-1 \\
0 \\
0\end{array}$ & $\begin{array}{l}95 \\
8.570 \\
5.700 \\
3.500\end{array}$ & $\begin{array}{r}3 \quad \mathrm{RB} \\
6.0 \\
85.0 \\
9.0\end{array}$ & 0.38 & COMM-95 \\
\hline
\end{tabular}

TX-5142

(7-.13-02) 


\begin{tabular}{|c|c|c|c|c|c|c|c|c|c|c|}
\hline \multicolumn{11}{|c|}{ BETA-RAY DATA TABLE } \\
\hline \multirow{2}{*}{$\begin{array}{l}Z \\
F\end{array}$} & \multirow{2}{*}{$\begin{array}{c}A \quad \\
E_{\beta}\end{array}$} & \multirow[t]{2}{*}{$N_{\beta}$} & \multirow{2}{*}{$A_{\beta}{ }^{E L}$} & \multirow{2}{*}{$\begin{array}{r}\dot{T}_{1 / 2} \\
-c_{1}\end{array}$} & & \multicolumn{5}{|c|}{ REFERENCES AND REMARKS } \\
\hline & & & & & $c_{2}$ & $c_{3}$ & & REMARKS & & \\
\hline $\begin{array}{r}38 \\
1 \\
-1 \\
-1 \\
-1 \\
-1 \\
0 \\
0\end{array}$ & $\begin{array}{l}95 \\
6.110 \\
5.420 \\
5.280 \\
4.200 \\
3.400 \\
3.200 \\
1.700\end{array}$ & 7 & $\begin{array}{r}\text { SR } \\
53.0 \\
13.0 \\
3.0 \\
5.0 \\
8.0 \\
15.0 \\
3.0\end{array}$ & 25.10 & & IOI -7 & GAMMA & $\begin{array}{l}\text { (BETA): } \\
\text { PR C } 19 \text {; }\end{array}$ & $\begin{array}{l}T F \\
194\end{array}$ & $\begin{array}{l}\text { F ROM } \\
48\end{array}$ \\
\hline $\begin{array}{r}39 \\
1 \\
-1 \\
-1 \\
-1 \\
0 \\
0\end{array}$ & $\begin{array}{l}95 \\
4.430 \\
3.480 \\
2.500 \\
2.060 \\
1.250 \\
0.880\end{array}$ & 6 & $\begin{array}{r}Y \\
58.0 \\
3.0 \\
2.0 \\
4.0 \\
16.0 \\
17.0\end{array}$ & 630.00 & & TO I -7 & GAMMA & A. BETA & . & \\
\hline $\begin{array}{r}40 \\
-1 \\
1 \\
0 \\
0\end{array}$ & $\begin{array}{l}95 \\
1.120 \\
0.887 \\
0.396 \\
0.364\end{array}$ & 4 & $\begin{array}{r}\text { ZR } \\
0.1 \\
0.9 \\
44.3 \\
54.7\end{array}$ & $5.530 E+06$ & & TOI -7 & GAMMA & A. BETA & & \\
\hline $\begin{array}{r}441 \\
-1 \\
-5\end{array}$ & $\begin{array}{l}95 \\
0.958 \\
0.225\end{array}$ & 2 & $\begin{array}{r}\text { N B } \\
2.5 \\
72.0\end{array}$ & 313200.00 & & TOI -7 & GAMMA & $A$ (BETA) & & \\
\hline $\begin{array}{l}41 \\
-2\end{array}$ & $\begin{array}{l}95 \\
0.159\end{array}$ & & $\begin{array}{r}\text { NB } \\
100.0\end{array}$ & $3.037 \mathrm{E}+06$ & & TOI -7 & BETA, & GAMMA & & \\
\hline 36 & $\begin{array}{l}96 \\
-2.540\end{array}$ & 1 & $\mathrm{KR}$ & 0.44 & & & & EDF / B-I V & & \\
\hline $\begin{array}{r}37 \\
-1 \\
-1 \\
0 \\
0\end{array}$ & $\begin{array}{l}96 \\
10.490 \\
9.720 \\
6.600 \\
5.000\end{array}$ & 4 & $\begin{array}{r}\text { RB } \\
3.0 \\
2.0 \\
82.5 \\
12.5\end{array}$ & 0.20 & & COMM-9 & 6 & & & \\
\hline $\begin{array}{r}38 \\
-1 \\
-1 \\
0 \\
0\end{array}$ & $\begin{array}{l}96 \\
5.410 \\
4.860 \\
4.600 \\
3.550\end{array}$ & 4 & $\begin{array}{r}\text { SR } \\
3.0 \\
0.5 \\
93.0 \\
3.5\end{array}$ & 1.10 & & NP A 35 & 2,1 & AMMA & $2 \mathrm{P}$ & A 294,35 \\
\hline $\begin{array}{r}439 \\
-1 \\
0\end{array}$ & $\begin{array}{l}96 \\
3.400 \\
2.700\end{array}$ & 2 & $\begin{array}{r}Y \\
9.0 \\
91.0\end{array}$ & 9.80 & & TOI -7 & GAMMA & & & \\
\hline $\begin{array}{l}39 \\
-1 \\
-1\end{array}$ & $\begin{array}{l}96 \\
7.120 \\
5.520\end{array}$ & 2 & $\begin{array}{r}Y \\
95.0 \\
5.0\end{array}$ & 6.30 & & TOI -7 & BET & $\begin{array}{l}\text { GAMMA } \\
Q(B E T A)\end{array}$ & $2 P$ & A294, 35 \\
\hline
\end{tabular}

TX -5142

(7-13-82) 


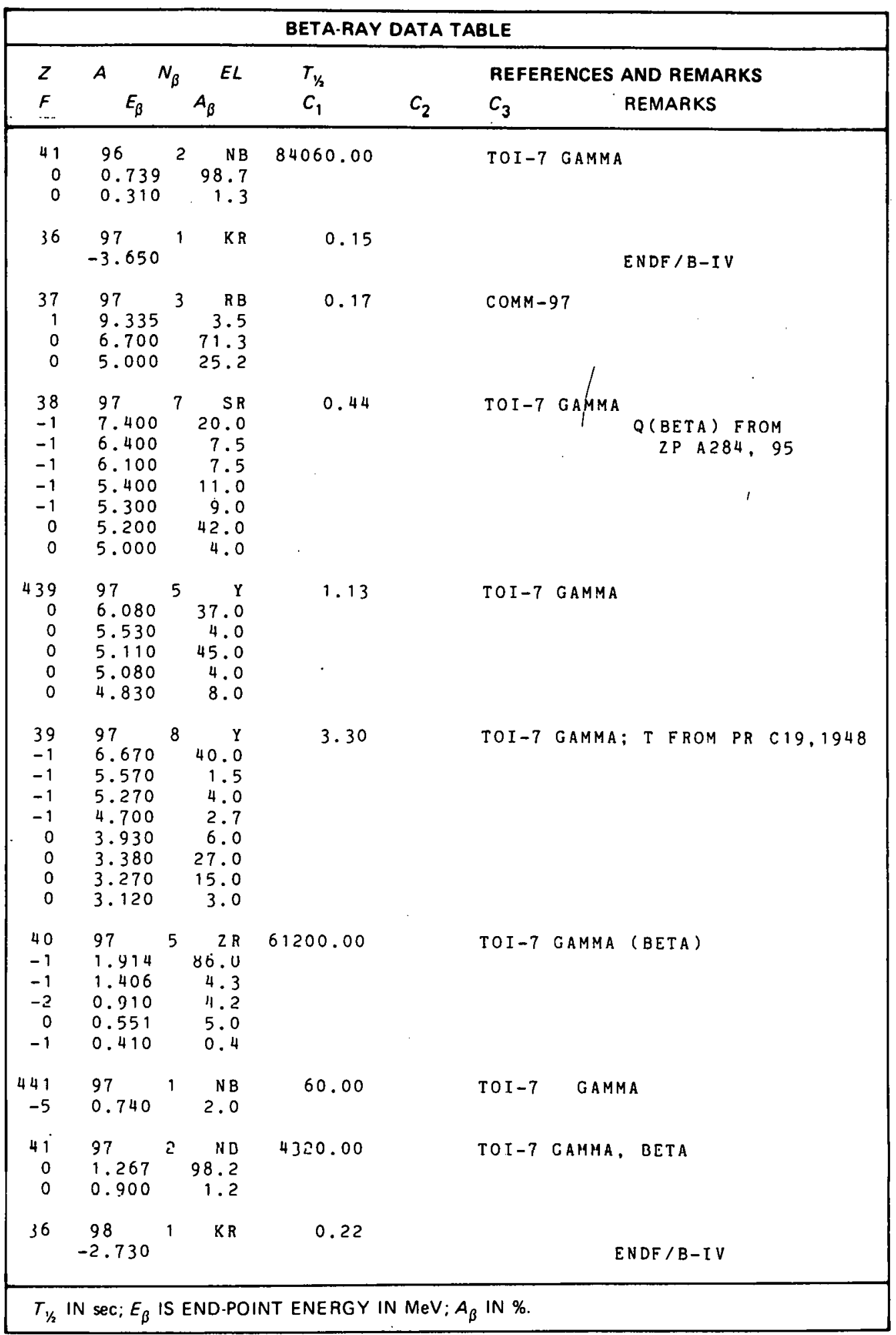

TX-5142

$(7-13-82)$ 


\begin{tabular}{|c|c|c|c|c|c|c|c|}
\hline \multicolumn{8}{|c|}{ BETA-RAY DATA TABLE } \\
\hline \multirow{2}{*}{$\begin{array}{l}Z \\
F\end{array}$} & \multirow{2}{*}{$\begin{array}{l}A \\
E_{\beta}\end{array}$} & \multirow[t]{2}{*}{$N_{\beta}$} & \multirow{2}{*}{$A_{\beta}{ }^{E L}$} & \multirow{2}{*}{$\begin{array}{l}T_{1 / 2} \\
C_{1}\end{array}$} & \multirow[b]{2}{*}{$C_{2}$} & \multicolumn{2}{|c|}{ REFERENCES AND REMARKS } \\
\hline & & & & & & $c_{3}$ & REMARKS \\
\hline $\begin{array}{l}37 \\
\cdots\end{array}$ & $\begin{array}{l}98 \\
-3.650\end{array}$ & 1 & RB & 0.11 & & COMM-9 & 8 NSE 80,74 \\
\hline $\begin{array}{r}38 \\
0 \\
-1 \\
-1 \\
0\end{array}$ & $\begin{array}{l}98 \\
5.810 \\
5.700 \\
5.640 \\
5.210\end{array}$ & 4 & $\begin{array}{r}\text { SR } \\
65.0 \\
4.5 \\
1.5 \\
29.0\end{array}$ & 0.80 & & TOI -7 & GAMMA \\
\hline $\begin{array}{r}439 \\
-1 \\
-1 \\
-1 \\
-1 \\
0\end{array}$ & $\begin{array}{l}98 \\
6.290 \\
6.250 \\
5.600 \\
5.300 \\
3.000\end{array}$ & 5 & $\begin{array}{r}Y \\
12.0 \\
25.0 \\
6.0 \\
7.0 \\
50.0\end{array}$ & 2.10 & & TOI -7 & GAMMA \\
\hline $\begin{array}{r}39 \\
0 \\
0 \\
0 \\
0 \\
0 \\
0 \\
0 \\
0 \\
0\end{array}$ & $\begin{array}{l}98 \\
8.100 \\
7.250 \\
6.880 \\
6.660 \\
6.510 \\
6.350 \\
6.230 \\
3.930 \\
3.650\end{array}$ & 9 & $\begin{array}{r}Y \\
51.0 \\
26.0 \\
1.6 \\
1.3 \\
2.1 \\
0.8 \\
2.2 \\
11.0 \\
11.0\end{array}$ & 0.65 & & TOI -7 & $\begin{array}{l}\text { GAMMA } \\
\qquad \text { ZP A284, } 95\end{array}$ \\
\hline $\begin{array}{r}40 \\
0\end{array}$ & $\begin{array}{l}98 \\
2.300\end{array}$ & & $\begin{array}{r}\text { ZR } \\
100.0\end{array}$ & 31.00 & & $T \cap T=7$ & RFTQ (NO GAMMAS ) \\
\hline $\begin{array}{r}441 \\
0 \\
0 \\
0 \\
0 \\
0\end{array}$ & $\begin{array}{l}98 \\
3.168 \\
2.445 \\
2.336 \\
2.269 \\
2.184\end{array}$ & 5 & $\begin{array}{r}\text { NB } \\
5.0 \\
16.0 \\
2.0 \\
1.5 \\
0.6\end{array}$ & 3078.00 & . & TOI -7 & GAMMA (BETA) \\
\hline $\begin{array}{r}41 \\
0 \\
0 \\
0 \\
0 \\
-1\end{array}$ & $\begin{array}{l}98 \\
4.590 \\
3.860 \\
3.160 \\
2.840 \\
2.400\end{array}$ & 5 & $\begin{array}{r}\text { N B } \\
90.0 \\
5.0 \\
1.6 \\
2.6 \\
0.7\end{array}$ & 2.90 & & TOI -7 & GAMMA, BETA \\
\hline 37 & $\begin{array}{l}99 \\
-3.270\end{array}$ & 1 & R $B$ & 0.08 & & & NSE 80,74 \\
\hline 38 & $\begin{array}{l}9 ? \\
-2.640\end{array}$ & 1 & SR & 0.29 & & T PROM & $\begin{array}{l}\text { IP } A 388,311 \\
\text { NSE } 80,74\end{array}$ \\
\hline
\end{tabular}

$T X-5142$

(7-13-82) 


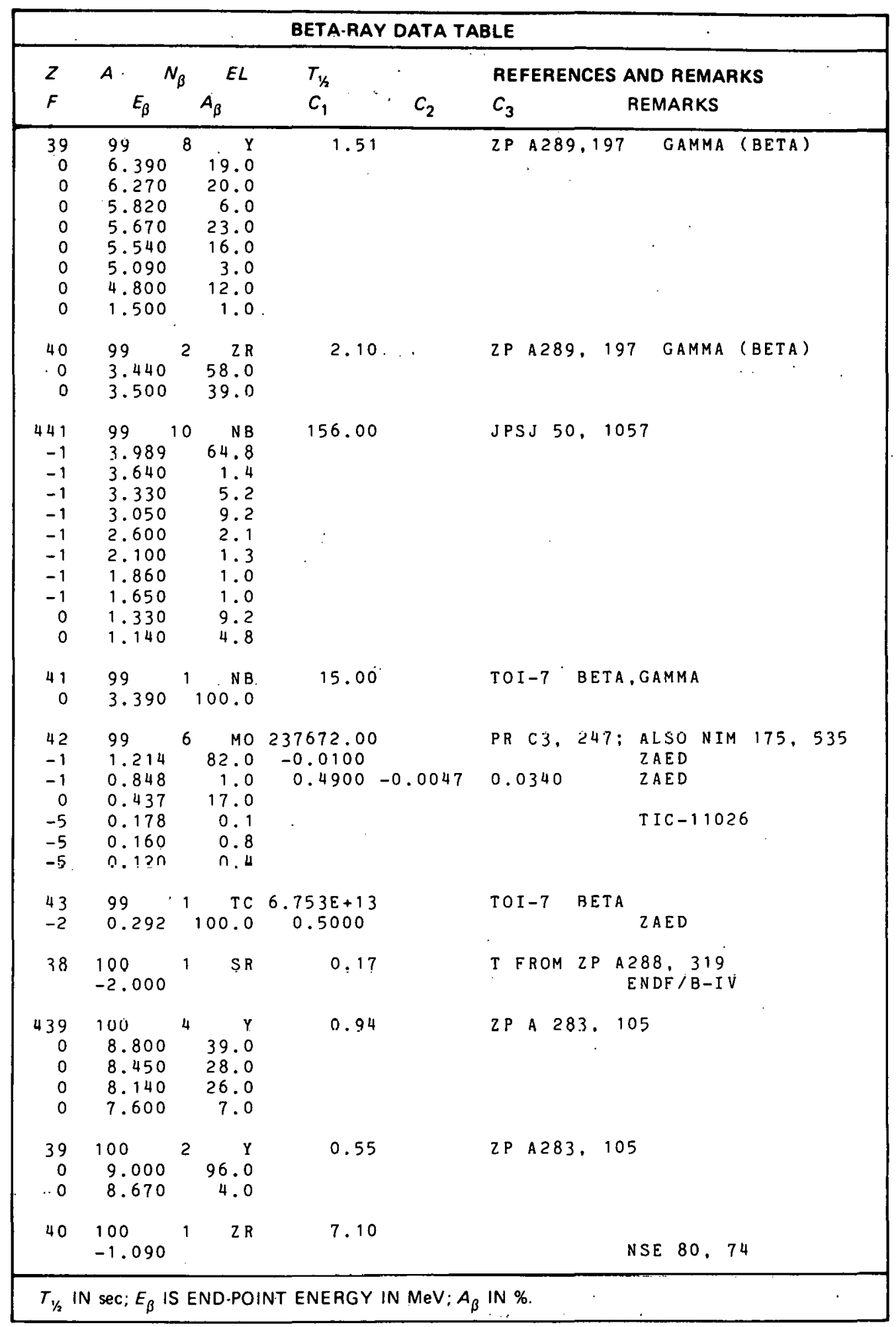

TX -5142

(7-13-82) 


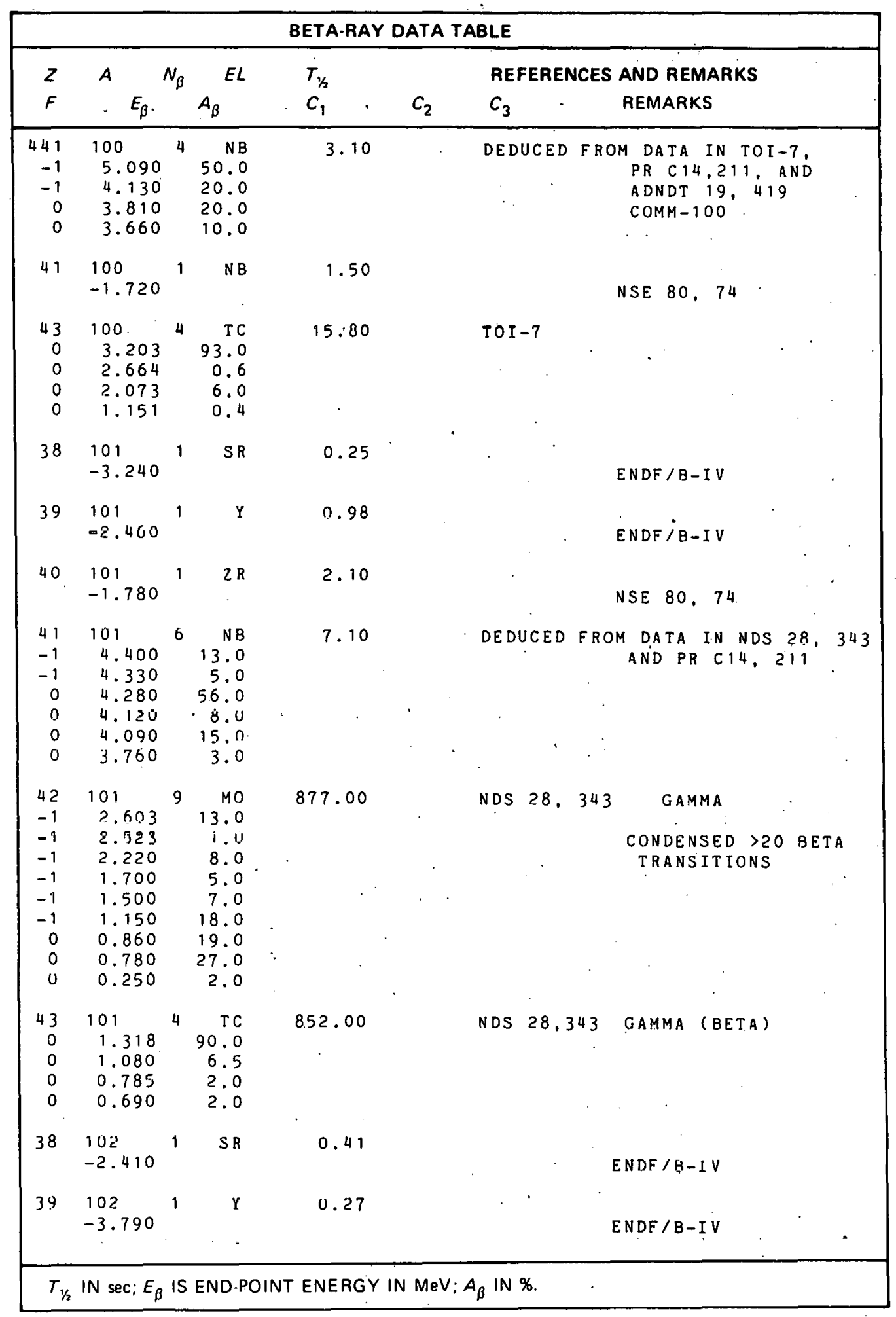

TX-5142

(7-13-82) 


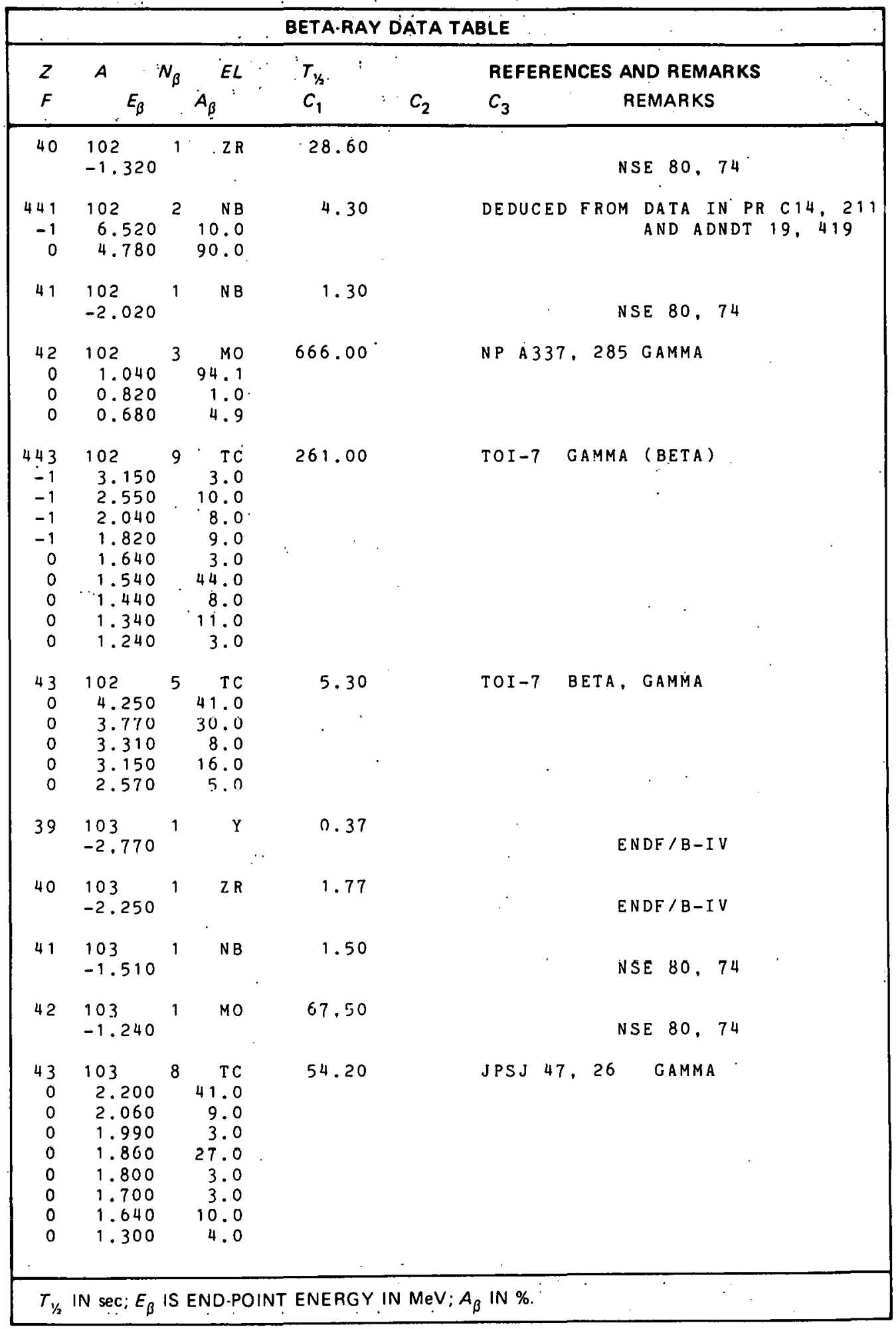

TX-5142

(7-13-82) 


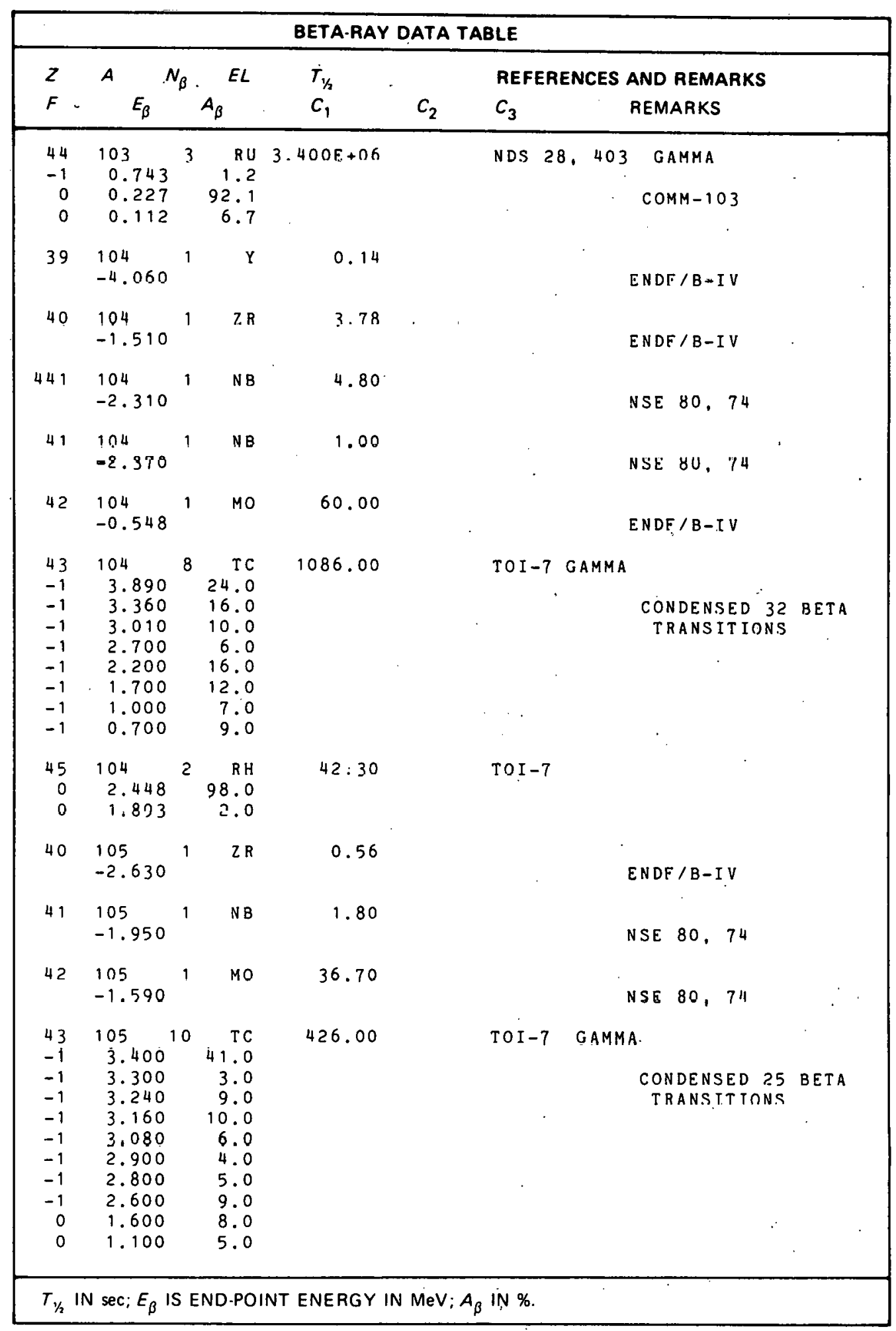

TX -5142

(7-13-82) 


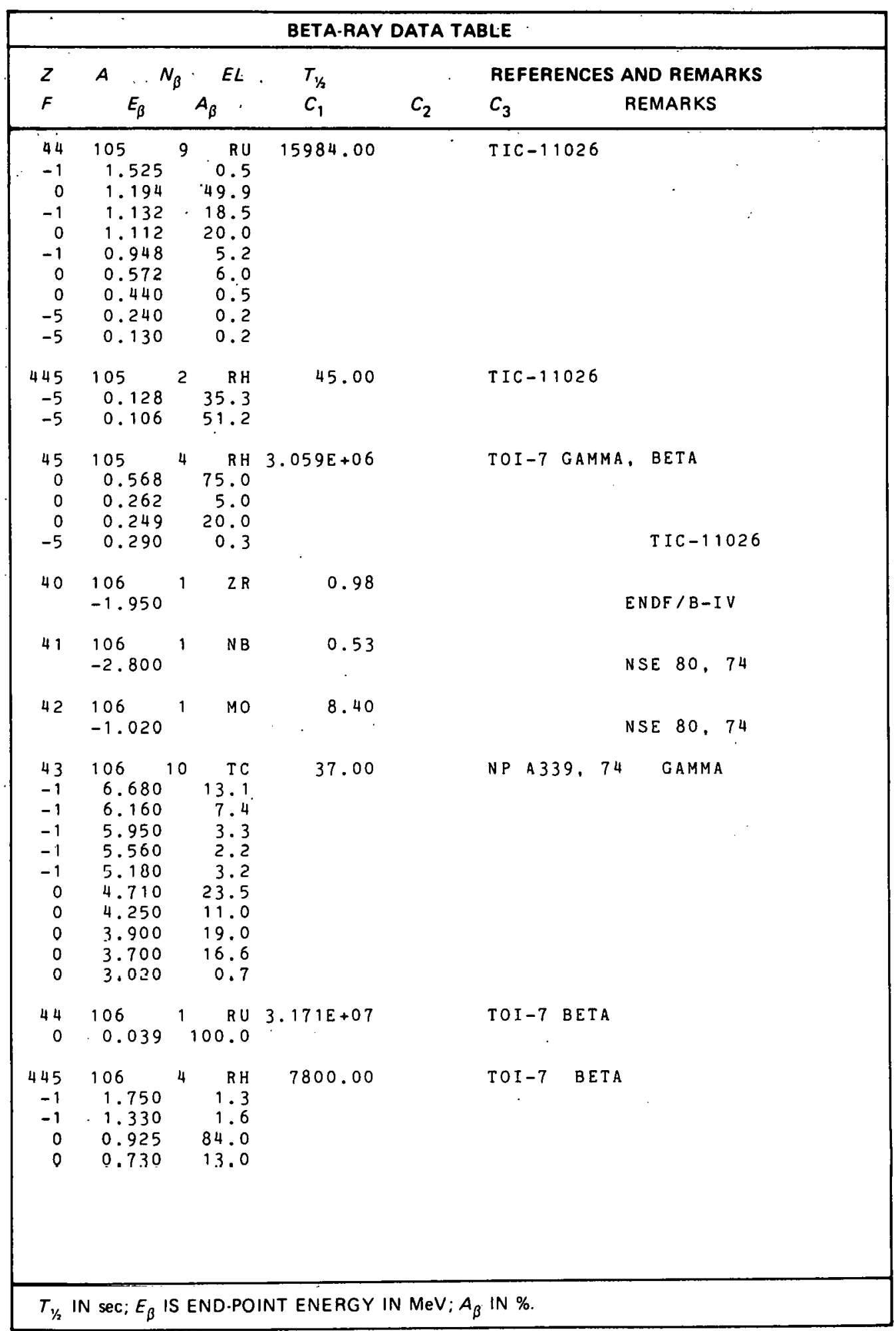

TX-5142

(7-13-82) 


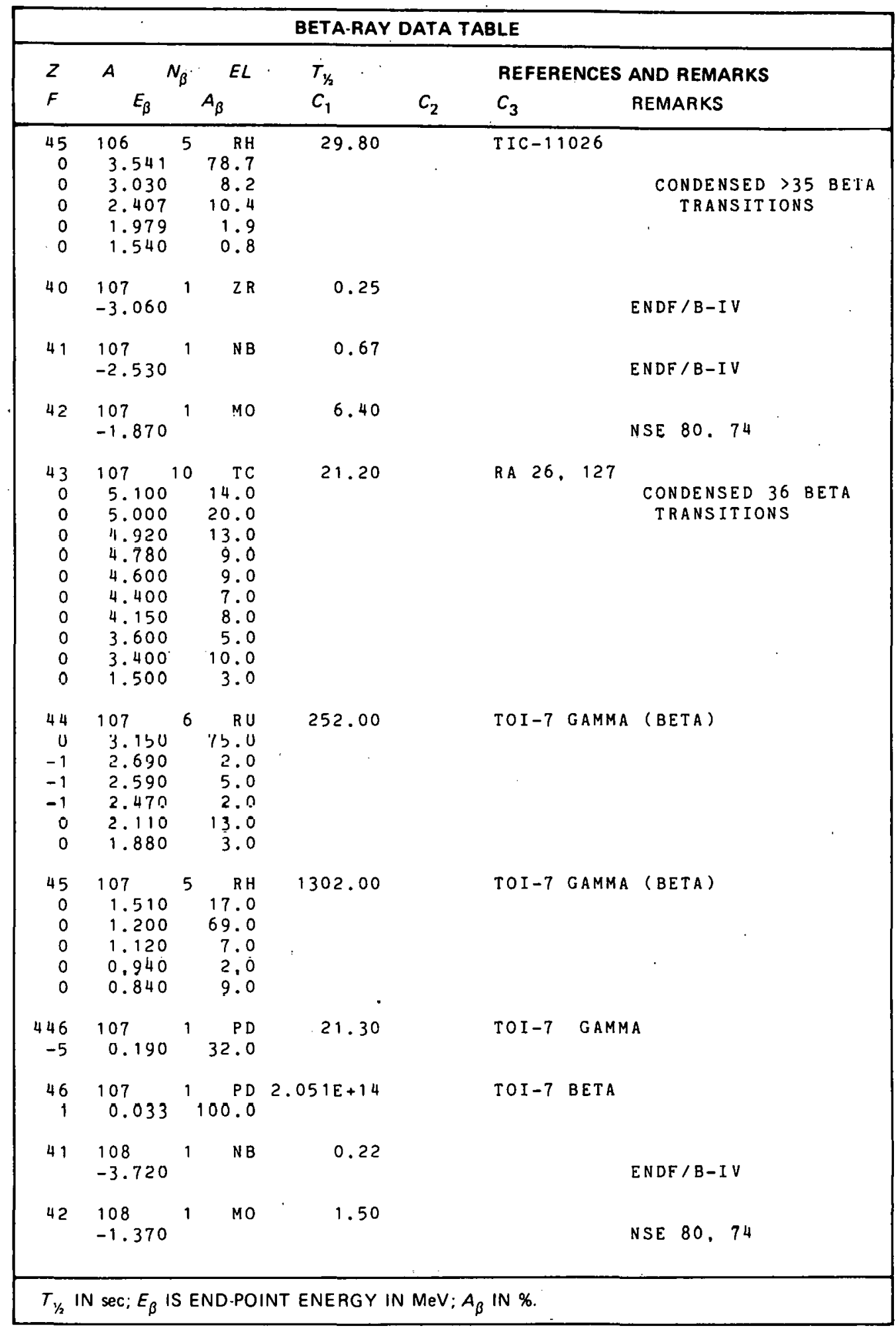

TX -5142

$(7-13-82)$ 


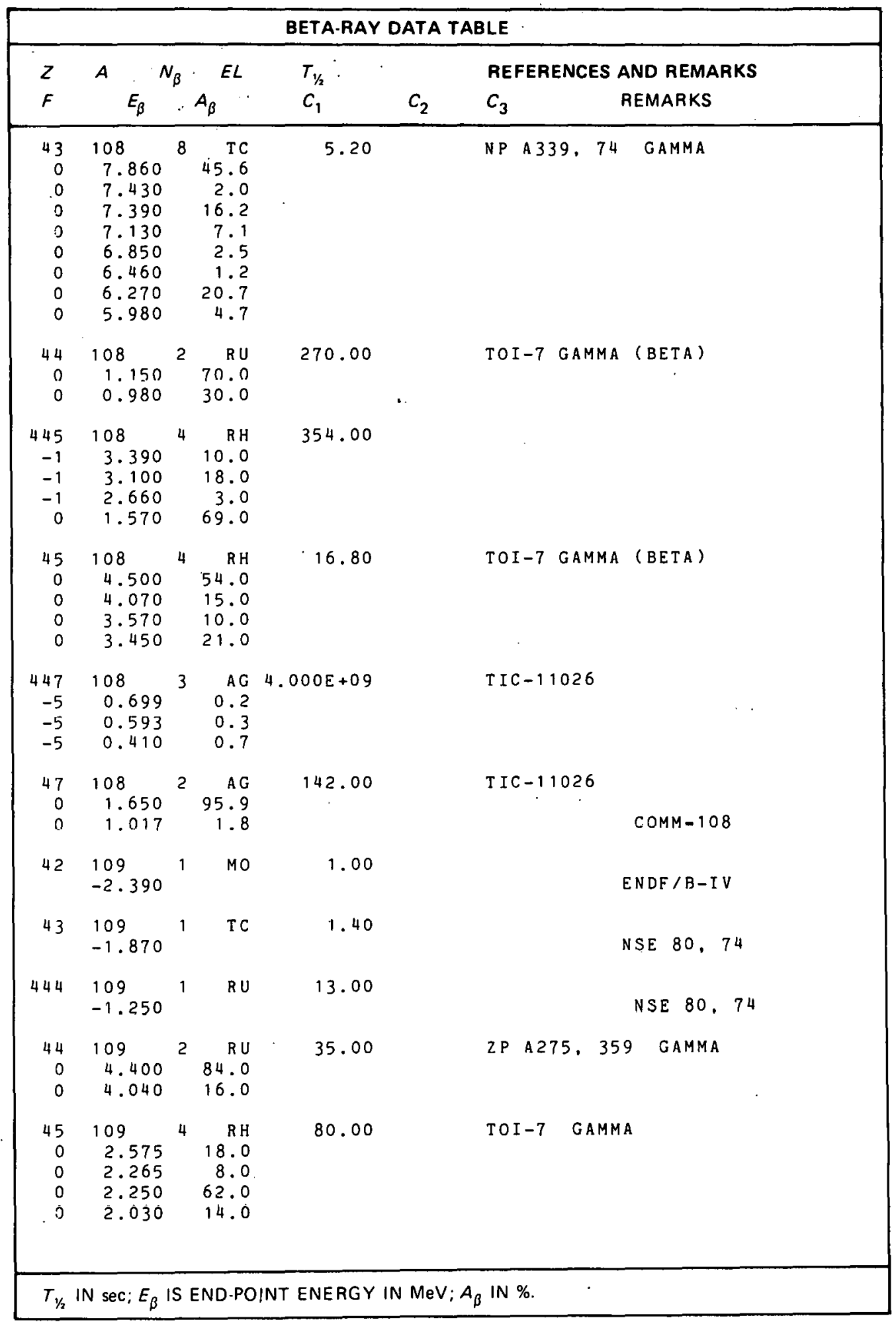

TX -5142

(7-13-82) 


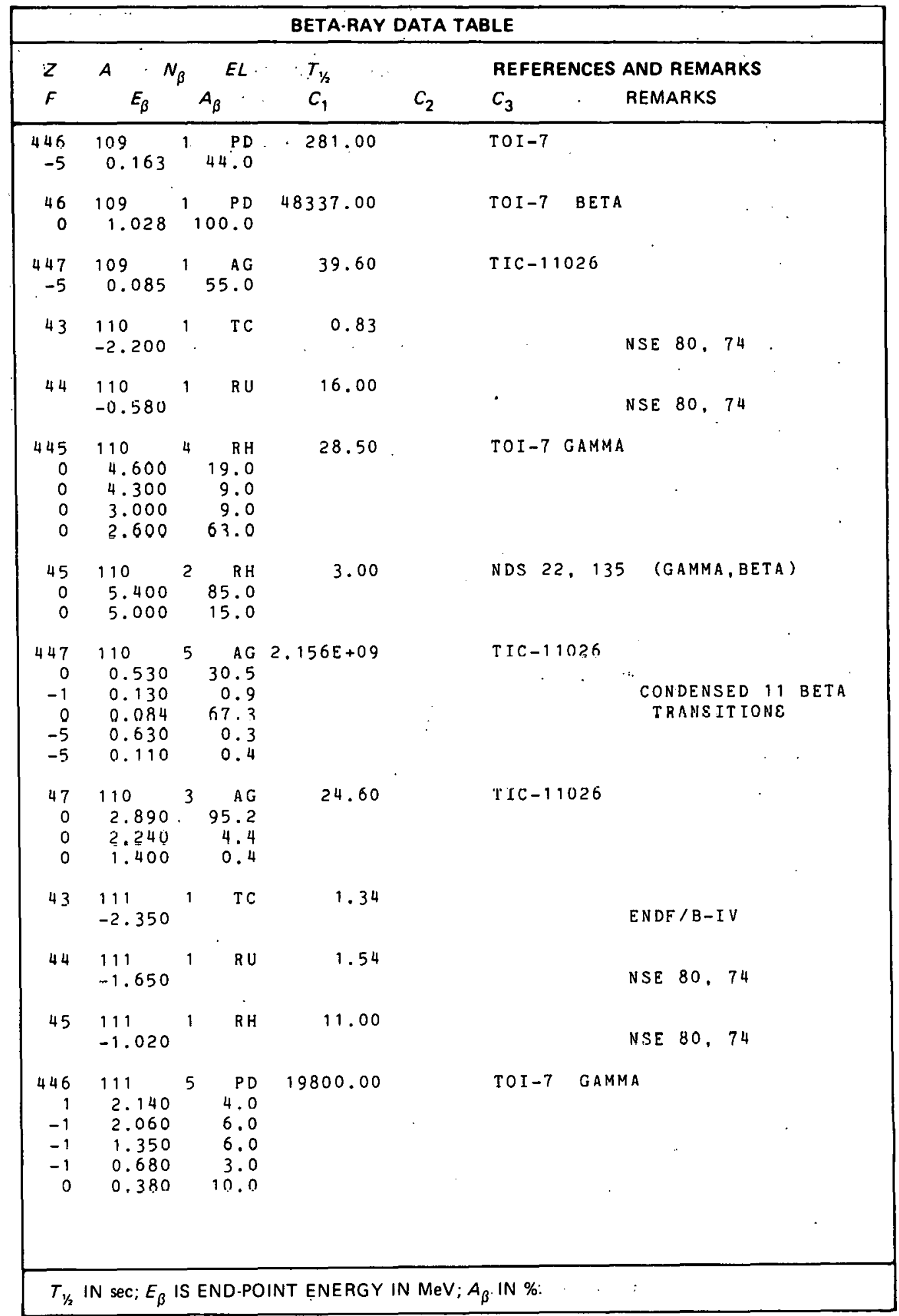

TX-5142

(7-13-82) 


\begin{tabular}{|c|c|c|c|c|c|}
\hline \multicolumn{6}{|c|}{ BETA-RAY DATA TABLE } \\
\hline \multirow{2}{*}{$\begin{array}{l}Z \\
F\end{array}$} & \multirow{2}{*}{${ }^{A} \quad E_{\beta}$} & $E L$ & \multirow{2}{*}{$\begin{array}{l}T_{1 / 2} \\
C_{1}\end{array}$} & & REFERENCES AND REMARKS \\
\hline & & $A_{\beta}$ & & $c_{2}$ & $c_{3} \quad$ REMARKS \\
\hline $\begin{array}{r}46 \\
0 \\
-1 \\
-1\end{array}$ & $\begin{array}{l}111 \\
2.140 \\
1.400 \\
0.700\end{array}$ & $\begin{array}{r}3 \quad P D \\
96.0 \\
3.0 \\
1.0\end{array}$ & - & & TOI-7 (MOSTLY G.S. BETA) \\
\hline $\begin{array}{r}+7 \\
-1 \\
1 \\
-1\end{array}$ & $\begin{array}{l}111 \\
1.028 \\
0.783 \\
0.687\end{array}$ & $\begin{array}{r}3 \quad A G \\
91.9 \\
1.1 \\
7.0\end{array}$ & $\begin{array}{r}643680.00 \\
-0.0200\end{array}$ & & T IC-11026 \\
\hline $\begin{array}{r}448 \\
-5 \\
-5 \\
-5 \\
-5 \\
-5\end{array}$ & $\begin{array}{l}111 \\
0.242 \\
0.218 \\
0.151 \\
0.147 \\
0.124\end{array}$ & $\begin{array}{r}5 \quad C D \\
1.0 \\
5.0 \\
4.9 \\
20.4 \\
43.8\end{array}$ & 2922.00 & & TIC-11026 \\
\hline 43 & $\begin{array}{l}112 \\
-3.440\end{array}$ & TC & 0.36 & & ENDE / B-IV \\
\hline 44 & $\begin{array}{l}112 \\
-1.070\end{array}$ & RU & 0.70 & & NSE 80,74 \\
\hline 45 & $\begin{array}{l}112 \\
-1.930\end{array}$ & $\mathrm{RH}$ & 4.70 & & NSE 80,74 \\
\hline $\begin{array}{r}46 \\
0\end{array}$ & $\begin{array}{l}112 \\
0.293\end{array}$ & $\begin{array}{r}1 P D \\
100.0\end{array}$ & 75960.00 & & NDS 29,587 BETA \\
\hline $\begin{array}{r}47 \\
1 \\
-1 \\
1 \\
-1 \\
-1\end{array}$ & $\begin{array}{l}112 \\
3.958 \\
3.341 \\
2.540 \\
1.950 \\
1.290\end{array}$ & $\begin{array}{r}5 A G \\
.54 .0 \\
21.0 \\
7.0 \\
10.0 \\
8.0\end{array}$ & 11304.00 & & NDS 29,587 BETA (GAMMA) \\
\hline 44 & $\begin{array}{l}113 \\
-1.980\end{array}$ & RU & 2.77 & & NSE 80,74 \\
\hline 45 & $\begin{array}{l}113 \\
-1.570\end{array}$ & $\mathrm{RH}$ & 0.90 & & NSE 80,74 \\
\hline $\begin{array}{r}46 \\
0 \\
0 \\
0 \\
0 \\
0 \\
0\end{array}$ & $\begin{array}{l}113 \\
3.360 \\
3.260 \\
3.140 \\
2.790 \\
2.620 \\
2.390\end{array}$ & $\begin{array}{r}6 \quad P D \\
91.0 \\
0.9 \\
1.2 \\
0.7 \\
5.1 \\
1.1\end{array}$ & 93.00 & & $\begin{array}{c}\text { ADAPTED FROM NDS } 33,1 \\
\text { COMM-113 }\end{array}$ \\
\hline $\begin{array}{r}447 \\
0 \\
0 \\
0 \\
0\end{array}$ & $\begin{array}{l}113 \\
1.700 \\
1.570 \\
1.430 \\
1.300\end{array}$ & $\begin{array}{r}4 \quad A G \\
25.0 \\
14.0 \\
11.0 \\
50.0\end{array}$ & 69.00 & & TOI-7 GAMMA, BETA \\
\hline
\end{tabular}

TX-5142

(7-13-82) 


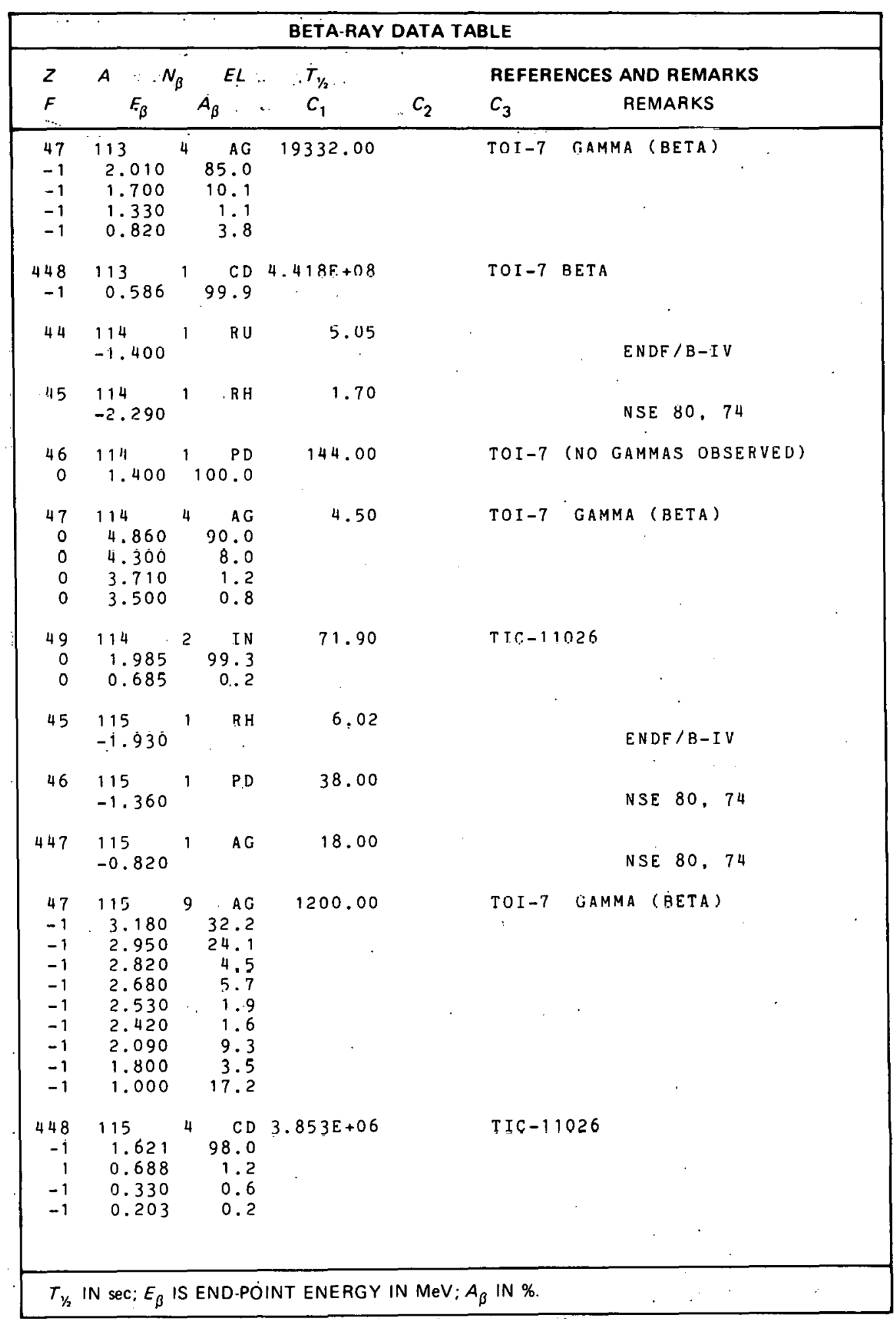

TX-5142

(7-13-82) 


\begin{tabular}{|c|c|c|c|c|c|c|c|}
\hline \multicolumn{8}{|c|}{ BETA-RAY DATA TABLE } \\
\hline \multirow{2}{*}{$\begin{array}{l}Z \\
F\end{array}$} & \multirow{2}{*}{$\begin{array}{lll}A & \\
& E_{\beta}\end{array}$} & \multirow{2}{*}{$N_{\beta}$} & \multirow{2}{*}{$A_{\beta}{ }^{E L}$} & \multirow{2}{*}{$\begin{array}{l}T_{1 / 2} \\
C_{1}\end{array}$} & \multicolumn{3}{|c|}{ REFERENCES AND REMARKS } \\
\hline & & & & & $c_{2}$ & $c_{3}$ & REMARKS \\
\hline $\begin{array}{r}48 \\
-1 \\
-1 \\
0 \\
0\end{array}$ & $\begin{array}{l}115 \\
1.111 \\
0.851 \\
0.619 \\
0.584\end{array}$ & $\begin{array}{ll} & 4 \\
1 & \\
1 \\
9 \\
4\end{array}$ & $\begin{array}{r}C D \\
60.1 \\
1.3 \\
3.4 \\
33.0\end{array}$ & 192240.00 & & TIC-11026 & \\
\hline $\begin{array}{r}449 \\
-1 \\
-5 \\
-5\end{array}$ & $\begin{array}{l}115 \\
0.860 \\
0.330 \\
0.310\end{array}$ & $\begin{array}{l}3 \\
0 \\
0\end{array}$ & $\begin{array}{r}\text { IN } \\
3.6 \\
10.3 \\
39.2\end{array}$ & 16164.00 & & I IC -11026 & \\
\hline 45 & $\begin{array}{l}116 \\
-3.040\end{array}$ & 1 & $\mathrm{RH}$ & 0.83 & & & ENDF / B-IV \\
\hline $\begin{array}{r}46 \\
0 \\
0 \\
0\end{array}$ & $\begin{array}{l}116 \\
2.500 \\
2.400 \\
2.220\end{array}$ & 3 & $\begin{array}{r}P D \\
79.0 \\
2.0 \\
19.0\end{array}$ & 12.70 & & NDS 32,287 & \\
\hline $\begin{array}{r}447 \\
0 \\
0 \\
0 \\
0 \\
0 \\
0 \\
0\end{array}$ & $\begin{array}{l}116 \\
5.390 \\
4.690 \\
3.980 \\
3.870 \\
3.650 \\
3.400 \\
2.940\end{array}$ & 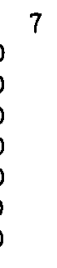 & $\begin{array}{r}\text { AG } \\
21.2 \\
26.0 \\
2.3 \\
6.5 \\
3.4 \\
6.7 \\
32.3\end{array}$ & .10 .40 & & NDS 32,287 & 7 \\
\hline $\begin{array}{r}47 \\
-1 \\
-1 \\
-1 \\
-1 \\
-1 \\
0 \\
0 \\
0 \\
0 \\
0\end{array}$ & $\begin{array}{l}116 \\
5.310 \\
4.600 \\
4.180 \\
3.900 \\
3.600 \\
3.300 \\
3.000 \\
2.650 \\
2.450 \\
1.900\end{array}$ & 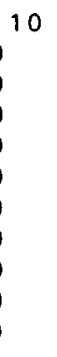 & $\begin{array}{r}P D \\
25.6 \\
6.8 \\
3.8 \\
7.5 \\
2.0 \\
12.4 \\
10.7 \\
17.2 \\
12.8 \\
1.2\end{array}$ & 161.00 & & NDS 32,287 & $\begin{array}{l}7 \\
\text { CONDENSED } 29 \text { BETA } \\
\text { TRANSITIONS }\end{array}$ \\
\hline $\begin{array}{r}4 y \\
0 \\
0 \\
0 \\
0 \\
0 \\
0 \\
-5 \\
-5 \\
-5\end{array}$ & $\begin{array}{l}110 \\
1.009 \\
0.871 \\
0.599 \\
0.395 \\
0.354 \\
0.304 \\
0.388 \\
0.133 \\
0.110\end{array}$ & $y$ & $\begin{array}{r}1 \mathrm{~N} \\
50.8 \\
35.5 \\
10.2 \\
0.4 \\
2.7 \\
0.4 \\
0.3 \\
0.2 \\
0.9\end{array}$ & $324 y .00$ & & $\begin{array}{c}r \perp c-110<6 \\
.\end{array}$ & COMM-116 \\
\hline 45 & $\begin{array}{l}117 \\
-2.270\end{array}$ & 1 & $\mathrm{RH}$ & 0.30 & & & ENDF/B-IV \\
\hline
\end{tabular}

TX -5142

$(7-13-82)$ 


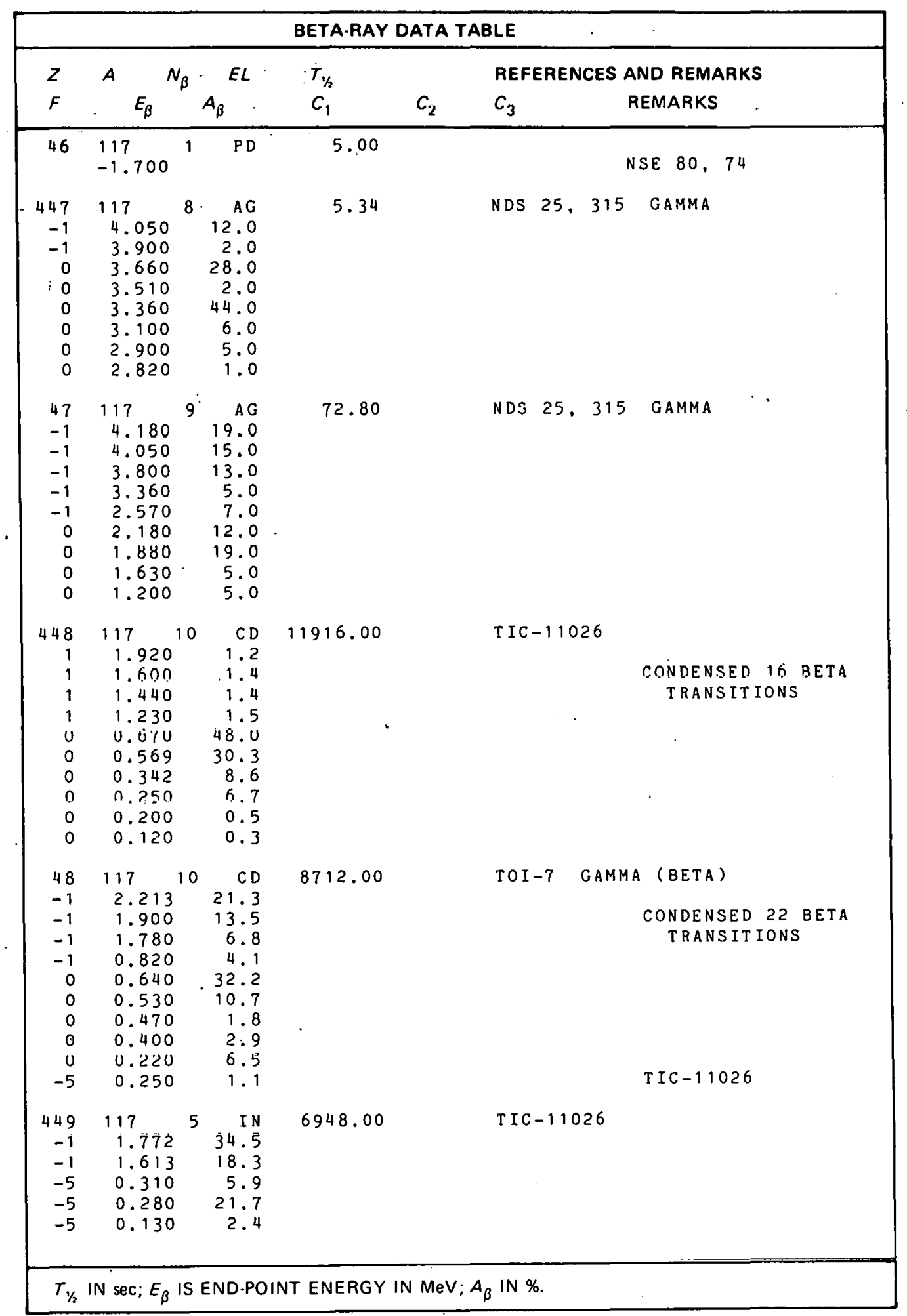

TX-5142

(7-13-82) 


\begin{tabular}{|c|c|c|c|c|c|c|}
\hline \multicolumn{7}{|c|}{ BETA-RAY DATA TABLE } \\
\hline \multirow{2}{*}{$\begin{array}{l}z \\
F\end{array}$} & \multirow{2}{*}{${ }^{A} E_{\beta}$} & \multirow{2}{*}{$A_{\beta}{ }^{E L}$} & \multirow{2}{*}{$\begin{array}{l}T_{1 / 2} \\
C_{1}\end{array}$} & & \multicolumn{2}{|c|}{ REFERENCES AND REMARKS } \\
\hline & & & & $c_{2}$ & $c_{3}$ & REMARKS \\
\hline $\begin{array}{r}49 \\
-1 \\
0 \\
-5 \\
-5 \\
-5\end{array}$ & $\begin{array}{l}117 \\
1.140 \\
0.740 \\
0.520 \\
0.155 \\
0.130\end{array}$ & $\begin{array}{r}5 \quad \text { IN } \\
0.2 \\
99.8 \\
0.5 \\
1.8 \\
11.6\end{array}$ & 2520.00 & & T I C -1 & 1026 \\
\hline $\begin{array}{r}450 \\
-5 \\
-5 \\
-5\end{array}$ & $\begin{array}{l}117 \\
0.155 \\
0.152 \\
0.128\end{array}$ & $\begin{array}{r}3 \mathrm{SN} \\
8.8 \\
26.1 \\
76.5\end{array}$ & $1.175 E+06$ & & I IC - 1 & 1026 \\
\hline 45 & $\begin{array}{l}118 \\
-3.480\end{array}$ & 1 & 0.30 & & & ENDF / B - I V \\
\hline 46 & $\begin{array}{l}118 \\
-1.120\end{array}$ & 1 & 3.10 & & & NSE 80,74 \\
\hline $\begin{array}{r}447 \\
0 \\
0 \\
-5\end{array}$ & $\begin{array}{l}118 \\
4.550 \\
4.280 \\
0.115\end{array}$ & $\begin{array}{r}3 \quad A G \\
26.0 \\
32.0 \\
36.0\end{array}$ & 2.80 & & TOI - 7 & GAMMA (BETA) \\
\hline $\begin{array}{r}47 \\
0 \\
0 \\
0 \\
0\end{array}$ & $\begin{array}{l}118 \\
6.500 \\
6.010 \\
5.340 \\
5.320\end{array}$ & $\begin{array}{r}4 \quad A G \\
25.0 \\
30.0 \\
30.0 \\
15.0\end{array}$ & 3.70 & & TOI -7 & GAMMA \\
\hline $\begin{array}{r}48 \\
0\end{array}$ & $\begin{array}{l}118 \\
0.750\end{array}$ & $\begin{array}{r}1 \quad C D \\
100.0\end{array}$ & 3018.00 & & TOI -7 & (NO GAMMA OBSERVED) \\
\hline $\begin{array}{r}449 \\
0 \\
0 \\
0\end{array}$ & $\begin{array}{l}118 \\
2.000 \\
1.800 \\
1.320\end{array}$ & $\begin{array}{r}3 \quad \mathrm{IN} \\
24.0 \\
12.0 \\
64.0\end{array}$ & 264.00 & & TOI -7 & GAMMA (BETA) \\
\hline $\begin{array}{r}49 \\
0 \\
0 \\
0 \\
0\end{array}$ & $\begin{array}{l}118 \\
4.200 \\
2.970 \\
2.440 \\
2.160\end{array}$ & $\begin{array}{r}4 \mathrm{IN} \\
85.0 \\
9.0 \\
5.0 \\
1.0\end{array}$ & 5.00 & & TOI -7 & BETA, GAMMA \\
\hline 46 & $\begin{array}{l}119 \\
-2.110\end{array}$ & PD & 1.71 & & & ENDF / B-IV \\
\hline $\begin{array}{r}47 \\
0 \\
0 \\
0 \\
0 \\
0 \\
0 \\
0 \\
0\end{array}$ & $\begin{array}{l}119 \\
4.260 \\
4.100 \\
3.070 \\
3.820 \\
3.500 \\
2.100 \\
2.480 \\
2.100\end{array}$ & $\begin{array}{r}8 \quad A G \\
3.0 \\
8.0 \\
31.0 \\
3.0 \\
12.0 \\
12.0 \\
2.0 \\
5.0\end{array}$ & 2.10 & & TOI -7 & GAMMA \\
\hline
\end{tabular}

TX -5142

(7-13-82) 


\begin{tabular}{|c|c|c|c|c|c|c|}
\hline \multirow{3}{*}{$\begin{array}{l}Z \\
F\end{array}$} & \multicolumn{6}{|c|}{ BETA-RAY DATA TABLE } \\
\hline & $A$ & $E L$ & \multirow{2}{*}{$\begin{array}{l}T_{1 / 2} \\
C_{1}\end{array}$} & \multirow[b]{2}{*}{$c_{2}$} & \multicolumn{2}{|c|}{ REFERENCES AND REMARKS } \\
\hline & $E_{\beta}$ & $A_{\beta}$ & & & $c_{3}$ & REMARKS \\
\hline $\begin{array}{r}448 \\
-1 \\
0 \\
0 \\
0 \\
0 \\
0 \\
0 \\
0 \\
0\end{array}$ & $\begin{array}{l}11.9 \\
2.290 \\
1.620 \\
1.520 \\
1.300 \\
1.270 \\
1.250 \\
1.160 \\
1.080 \\
0.970\end{array}$ & $\begin{array}{r}9 \quad C D \\
1.4 \\
30.0 \\
23.0 \\
4.9 \\
16.0 \\
11.0 \\
8.6 \\
3.3 \\
2.3\end{array}$ & 114.00 & & TOI -7 & GAMMA \\
\hline $\begin{array}{r}48 \\
-1 \\
-1 \\
-1 \\
=1 \\
-1 \\
0 \\
0 \\
0 \\
0\end{array}$ & $\begin{array}{l}119 \\
3.190 \\
2.900 \\
2.710 \\
2.460 \\
1.730 \\
1.580 \\
1.440 \\
1.140 \\
0.950\end{array}$ & $\begin{array}{r}\text { CD } \\
40.0 \\
5.0 \\
5.0 \\
1.0 \\
5.0 \\
15.0 \\
1.0 \\
25.0 \\
2.0\end{array}$ & 162.00 & . & $\mathrm{TOI}-7$ & GAMMA \\
\hline $\begin{array}{r}449 \\
-1 \\
-5\end{array}$ & $\begin{array}{l}119 \\
2.668 \\
0.300\end{array}$ & $\begin{array}{r}2 \quad \text { IN } \\
94.0 \\
5.0\end{array}$ & 1080.00 & & TOI -7 & GAMMA ( $B E T A)$ \\
\hline $\begin{array}{r}19 \\
0\end{array}$ & $\begin{array}{l}119 \\
1.550\end{array}$ & $\begin{array}{l}1 \quad \text { IN } \\
100.0\end{array}$ & 126.00 & & TOI -7 & GAMMA (BETA) \\
\hline 46 & $\begin{array}{l}120 \\
-1.340\end{array}$ & $\mathfrak{i} P D$ & 4.27 & & & FNDF/B-TV \\
\hline $\begin{array}{r}\| 17 \\
0 \\
0 \\
-5\end{array}$ & $\begin{array}{l}120 \\
4.200 \\
4.100 \\
0.190\end{array}$ & $\begin{array}{r}3 \quad A C \\
17.0 \\
40.0 \\
14.0\end{array}$ & 0.32 & & TOI -7 & GAMMA (DETA) \\
\hline $\begin{array}{r}47 \\
0 \\
0 \\
0 \\
0\end{array}$ & $\begin{array}{l}120 \\
6.200 \\
5.700 \\
5.000 \\
4.880\end{array}$ & $\begin{array}{r}4 \quad A G \\
20.0 \\
30.0 \\
30.0 \\
20.0\end{array}$ & 1.20 & & TOI -7 & GAMMA \\
\hline 48 & $\begin{array}{l}120 \\
-0.550\end{array}$ & $1 \quad C D$ & 50.80 & & & NSE 80.74 \\
\hline $\begin{array}{r}449 \\
0 \\
0 \\
0 \\
0 \\
0 \\
0\end{array}$ & $\begin{array}{l}120 \\
3.110 \\
2.650 \\
2.240 \\
2.120 \\
1.860 \\
1.630\end{array}$ & $\begin{array}{r}6 \quad \text { IN } \\
19.0 \\
6.0 \\
42.0 \\
14.0 \\
16.0 \\
3.0\end{array}$ & 44.00 & . & TOI -7 & GAMMA (BETA) \\
\hline
\end{tabular}

TX -5142

(7-13-82) 


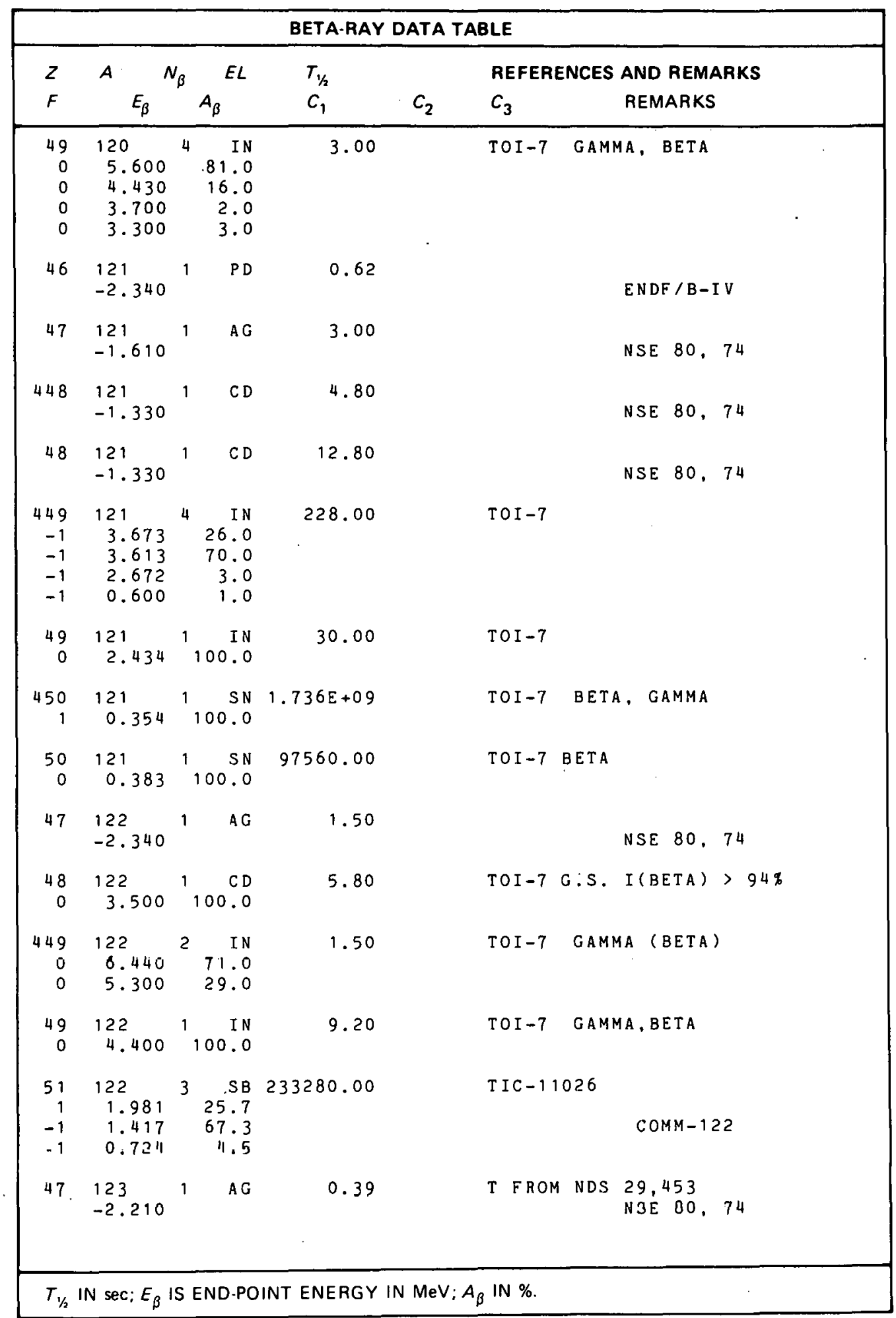

TX-5142

$(7-13-82)$ 


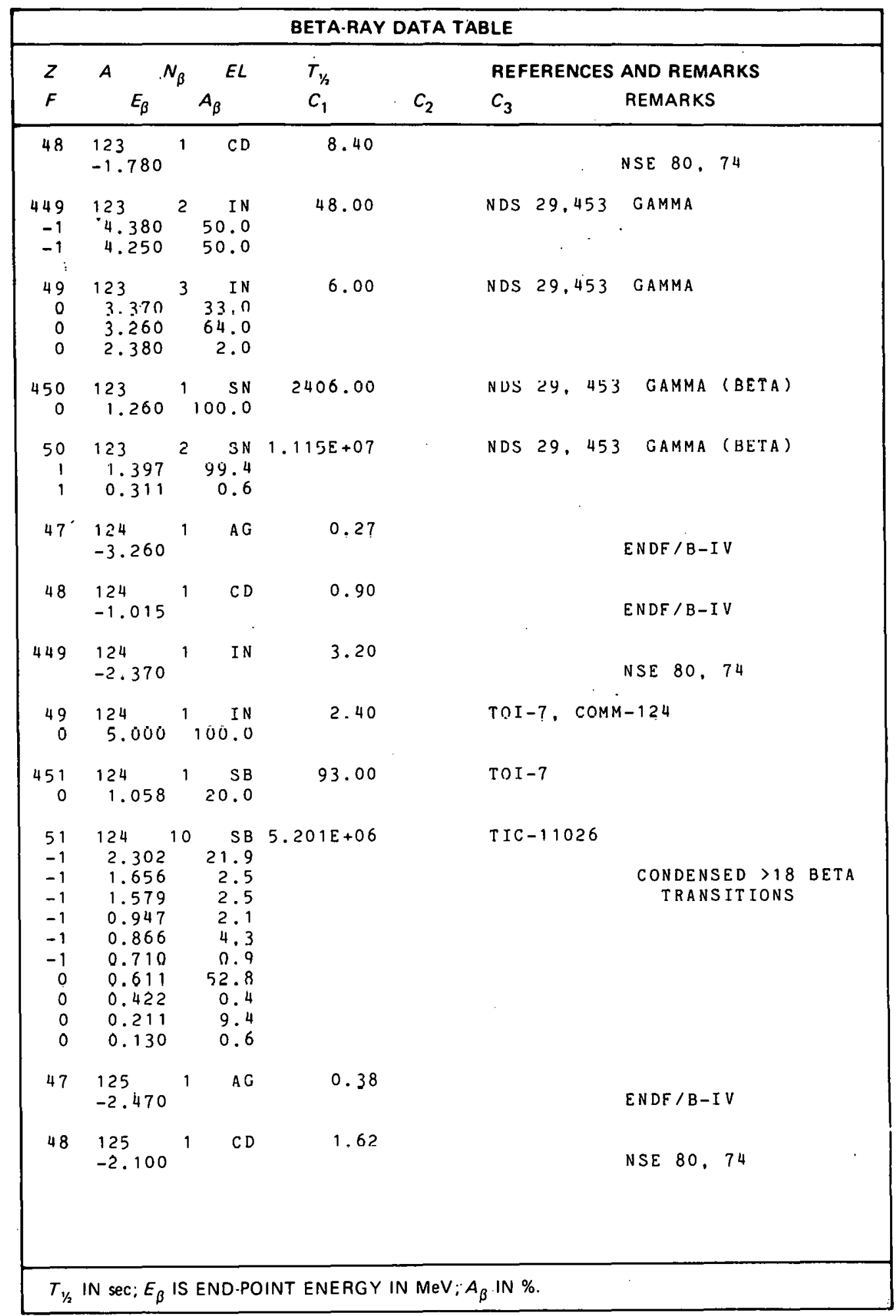




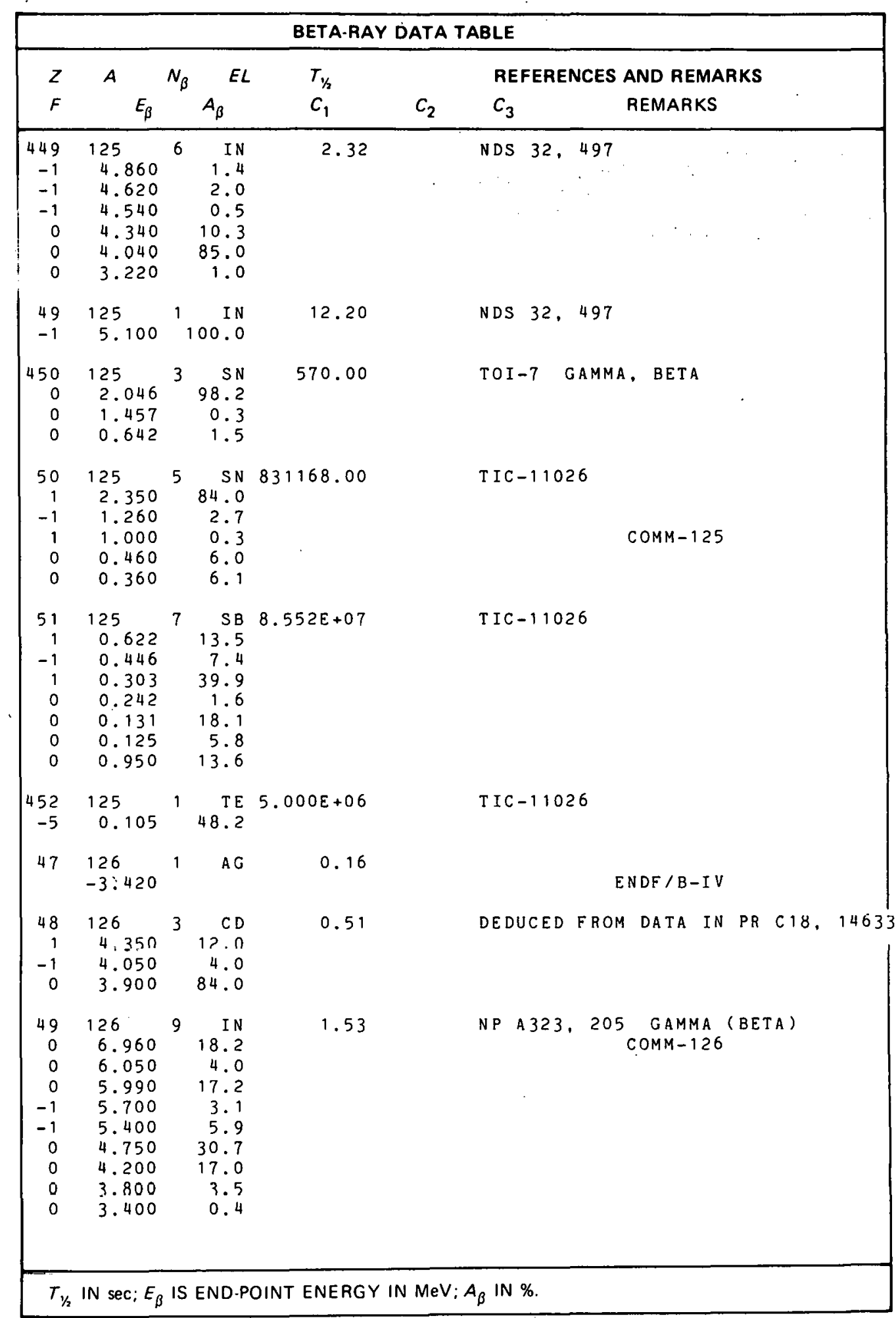

TX-5142

(7-13-82) 


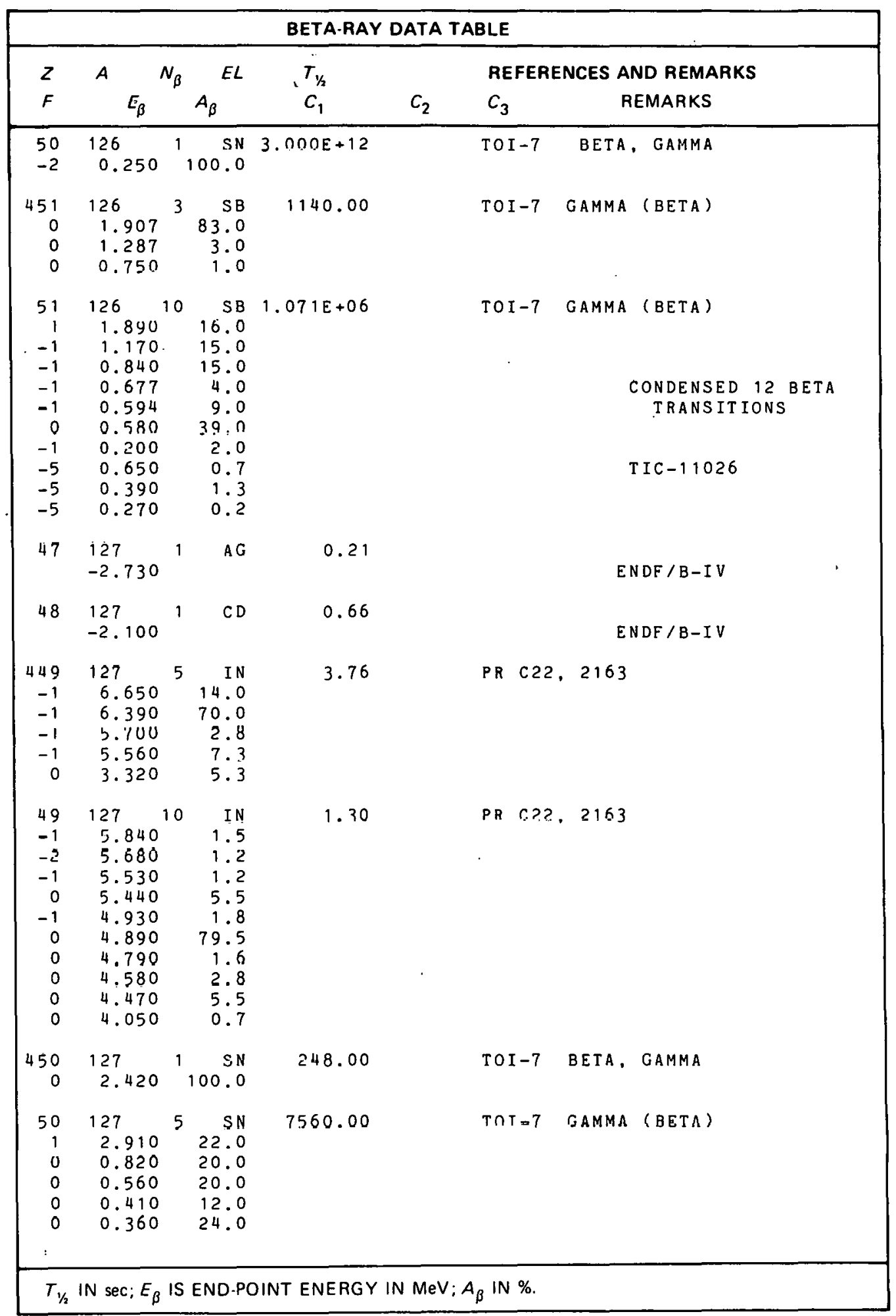




\section{5}

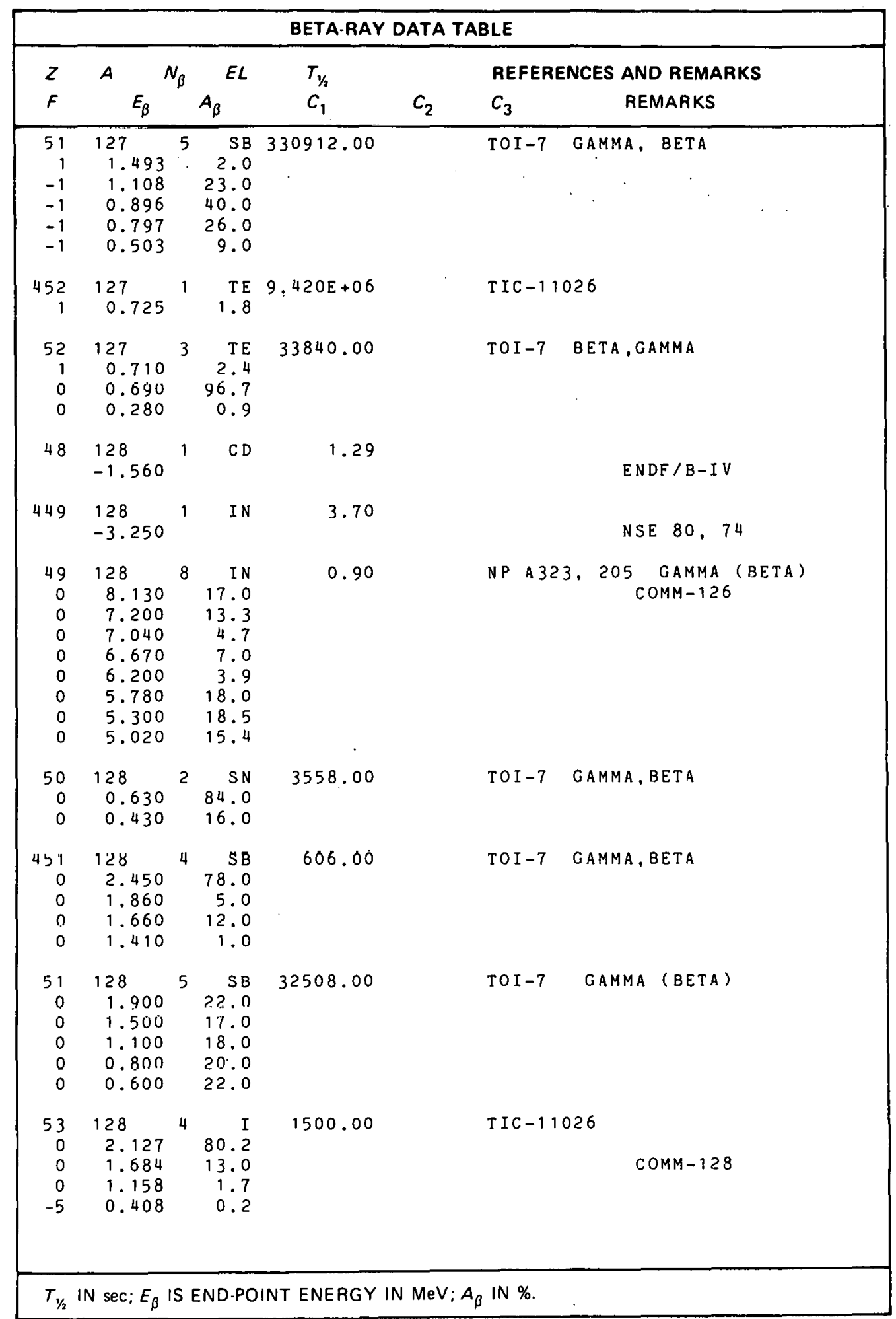

TX-5142

(7-13-82) 


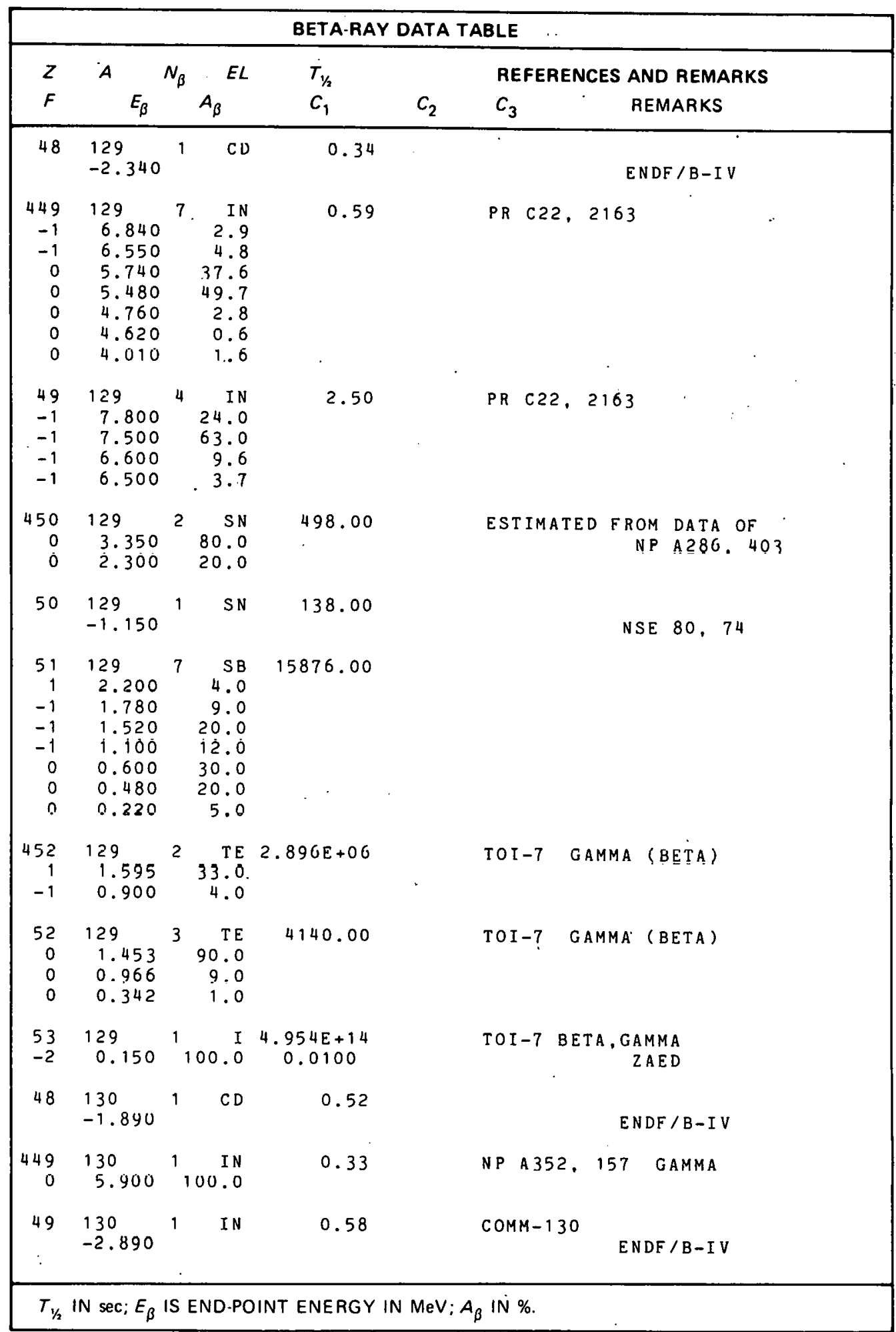

TX-5142

(7-13-82) 


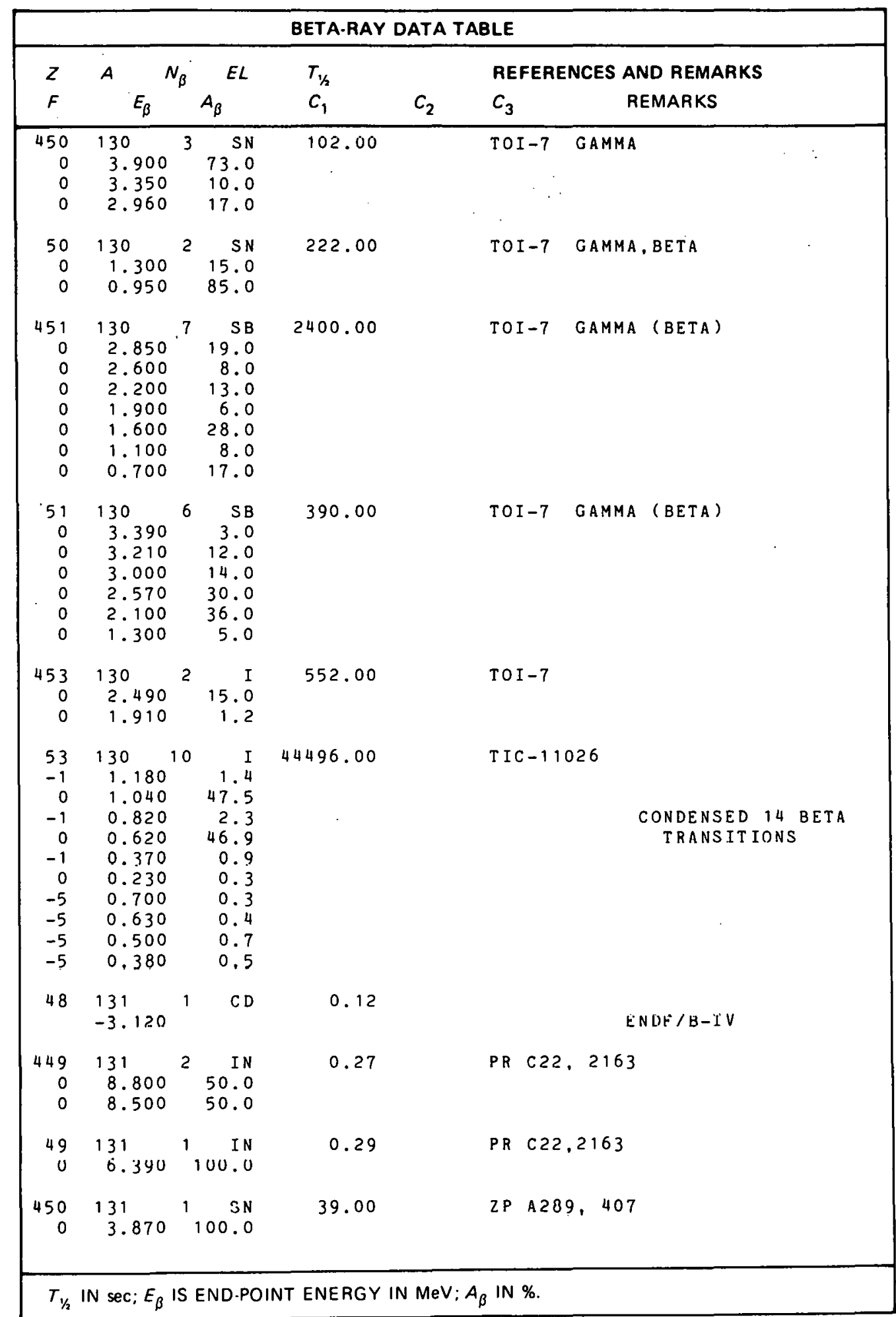

$T X-5142$

$(7-13-82)$ 


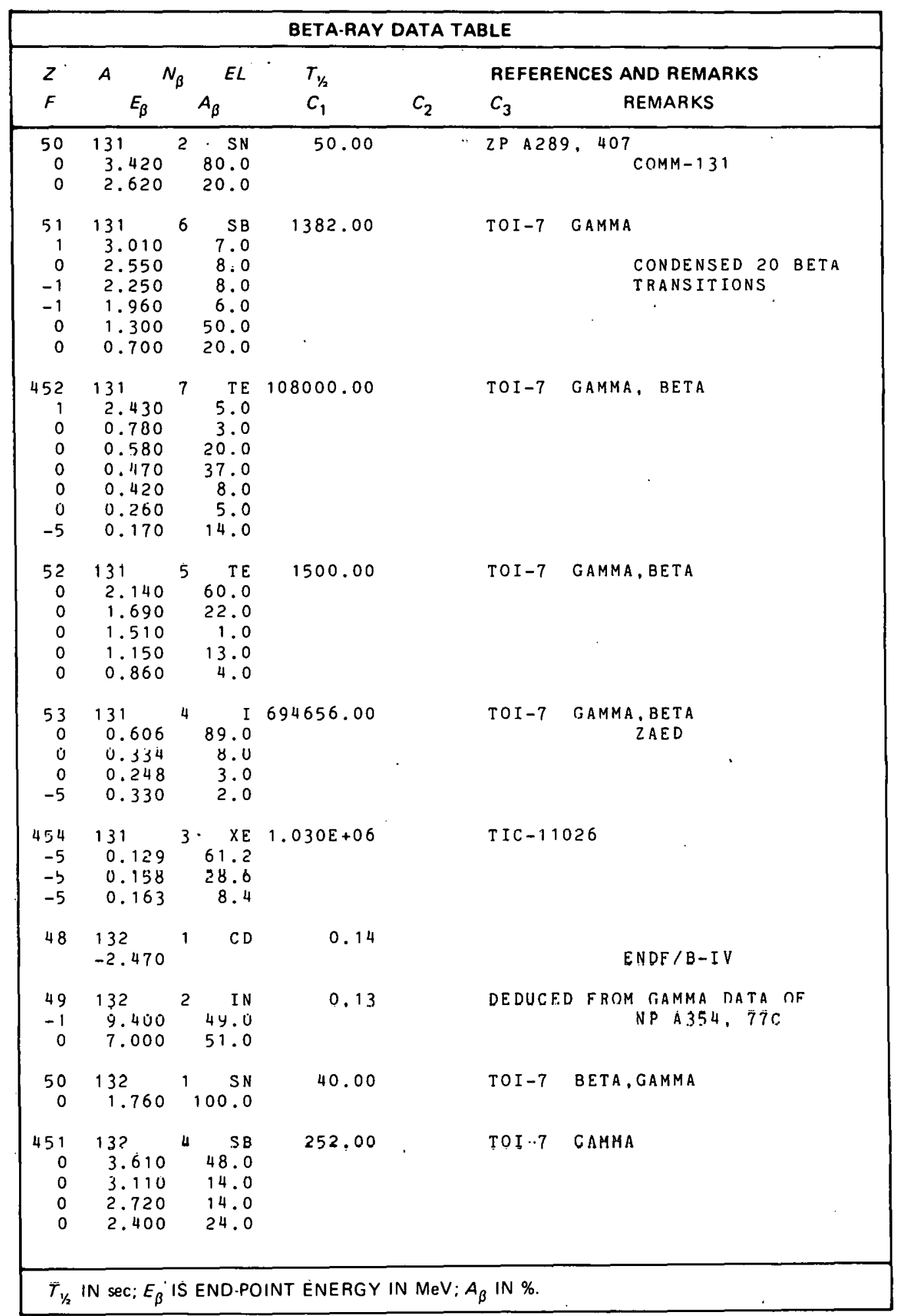

TX-5142

(7-13-82) 


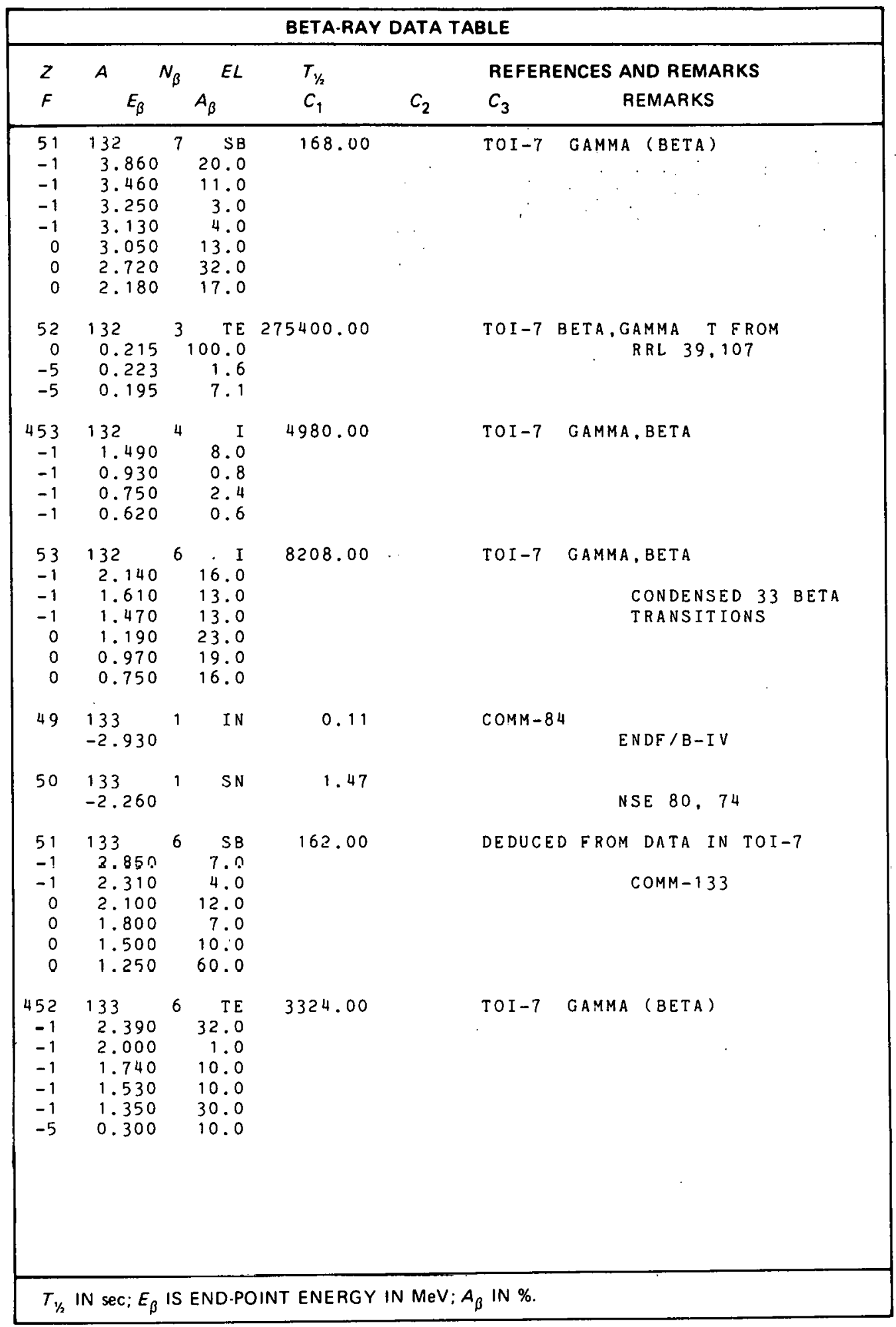

$T X-5142$

(7-13-32) 


\begin{tabular}{|c|c|c|c|c|c|c|c|c|}
\hline \multicolumn{8}{|c|}{ BETA-RAY DATA TABLE } & \\
\hline \multirow{2}{*}{$\begin{array}{l}Z \\
F\end{array}$} & \multirow{2}{*}{$E_{\beta}{ }^{\wedge}$} & \multirow{2}{*}{$A_{\beta}{ }^{E L}$} & \multirow{2}{*}{$\begin{array}{l}T_{1 / 2} \\
C_{1}\end{array}$} & \multirow[b]{2}{*}{$c_{2}$} & \multicolumn{3}{|c|}{ REFERENCES AND REMARKS } & \\
\hline & & & & & $c_{3}$ & REMARKS & . & \\
\hline $\begin{array}{r}52 \\
0 \\
0 \\
0 \\
0 \\
0 \\
0\end{array}$ & $\begin{array}{l}133 \\
2.660 \\
2.250 \\
1.640 \\
1.410 \\
1.260 \\
0.780\end{array}$ & $\begin{array}{r}\text { TE } \\
26.0 \\
35.0 \\
22.0 \\
5.0 \\
9.0 \\
3.0\end{array}$ & 744.00 & & TOI -7 & GAMMA (BETA) & · & \\
\hline $\begin{array}{r}53 \\
1 \\
0 \\
-1 \\
-1 \\
-1\end{array}$ & $\begin{array}{l}133 \\
1.530 \\
1.230 \\
1.020 \\
0.890 \\
0.500\end{array}$ & $\begin{array}{r}1 \\
1.0 \\
84.0 \\
2.0 \\
4.0 \\
9.0\end{array}$ & 14880.00 & & $101-1$ & CAMMA, BETA & & \\
\hline $\begin{array}{r}454 \\
-5 \\
-5\end{array}$ & $\begin{array}{l}133 \\
0.230 \\
0.199\end{array}$ & $\begin{array}{l}2 \quad X E \\
26.4 \\
63.3\end{array}$ & 189216.00 & & T IC -11 & 026 & & \\
\hline $\begin{array}{r}54 \\
0\end{array}$ & $\begin{array}{l}133 \\
0.347\end{array}$ & $\begin{array}{l}1 . X E \\
100.0\end{array}$ & 453168.00 & & I U I - T & BEETÁ, GAMMA & & \\
\hline 50 & $\begin{array}{l}134 \\
-1.890\end{array}$ & $1 \quad \mathrm{SN}$ & 1.04 & & & NSE 80,7 & & \\
\hline $\begin{array}{r}451 \\
0 \\
0\end{array}$ & $\begin{array}{l}134 \\
6.800 \\
6.100\end{array}$ & $\begin{array}{r}38 \\
43.0 \\
57.0\end{array}$ & 10.40 & & TOI - 7 & GAMMA (BETA) & & \\
\hline $\begin{array}{r}51 \\
0\end{array}$ & $\begin{array}{l}134 \\
8.400\end{array}$ & $\begin{array}{l}1 \text { SB } \\
100.0\end{array}$ & 0.85 & & $\mathrm{TOI}-7$ & BETA $Q(B E T A)$ & ZP & A 289,407 \\
\hline $\begin{array}{r}52 \\
0 \\
0 \\
0 \\
-5 \\
-5 \\
-5\end{array}$ & $\begin{array}{l}134 \\
0.450 \\
0.300 \\
0.190 \\
0.240 \\
0.180 \\
0.150\end{array}$ & $\begin{array}{r}6 \quad \text { TE } \\
4.00 \\
13.0 \\
15.0 \\
0.8 \\
4.0 \\
3.2\end{array}$ & 2508.00 & & TO I -7 & GAMMA & & \\
\hline $\begin{array}{r}453 \\
-1 \\
-5\end{array}$ & $\begin{array}{l}134 \\
2.500 \\
0.240\end{array}$ & $\begin{array}{rr}1 \\
2.0 \\
19.0\end{array}$ & 222.00 & & TOI -7 & GAMMA (BETA) & & \\
\hline $\begin{array}{r}53 \\
-1 \\
-1 \\
-1 \\
0 \\
0 \\
-1 \\
-1\end{array}$ & $\begin{array}{l}134 \\
2.410 \\
2.230 \\
1.800 \\
1.550 \\
1.290 \\
1.070 \\
0.780\end{array}$ & $\begin{array}{r}7 \\
12.0 \\
4.0 \\
18.0 \\
29.0 \\
32.0 \\
1.0 \\
2.0\end{array}$ & 3156.00 & & TO $1-7$ & GAMMA (BETA) & - & \\
\hline & & & 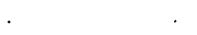 & & & & & \\
\hline
\end{tabular}

TX -5142

$(7-13-82)$ 
61

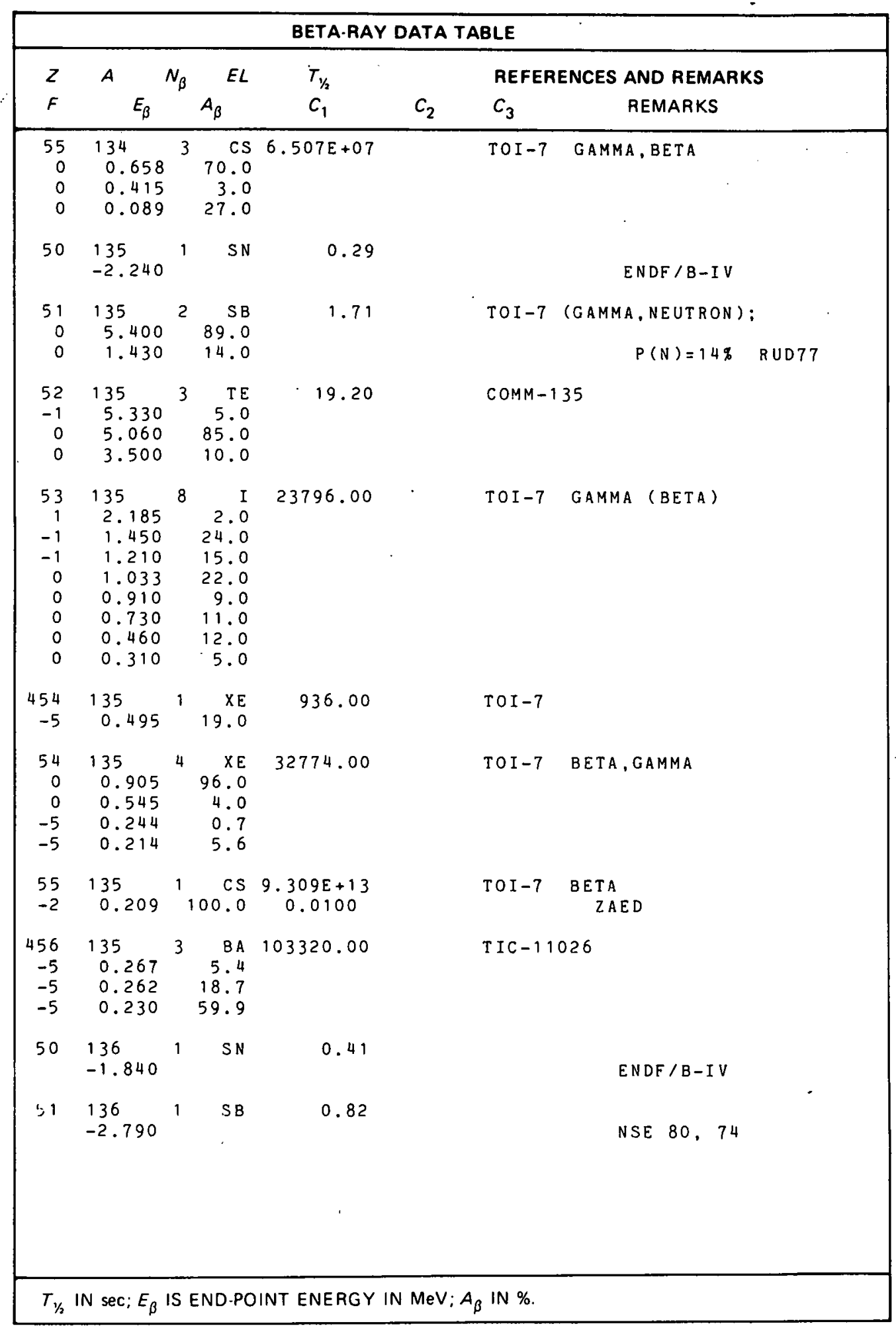

$T X-5142$

(7-13-82) 


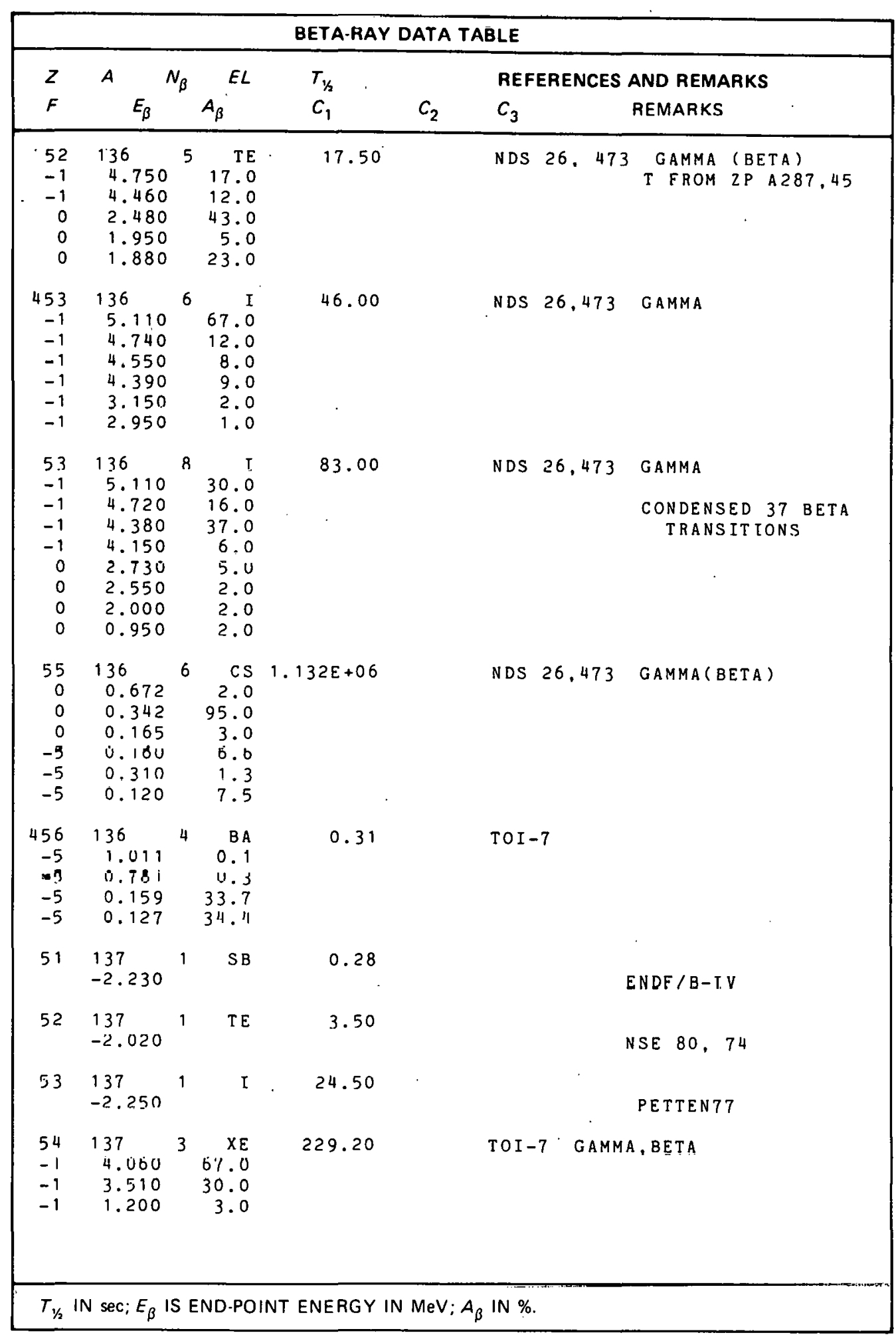

TX-5142

(7-13-82) 


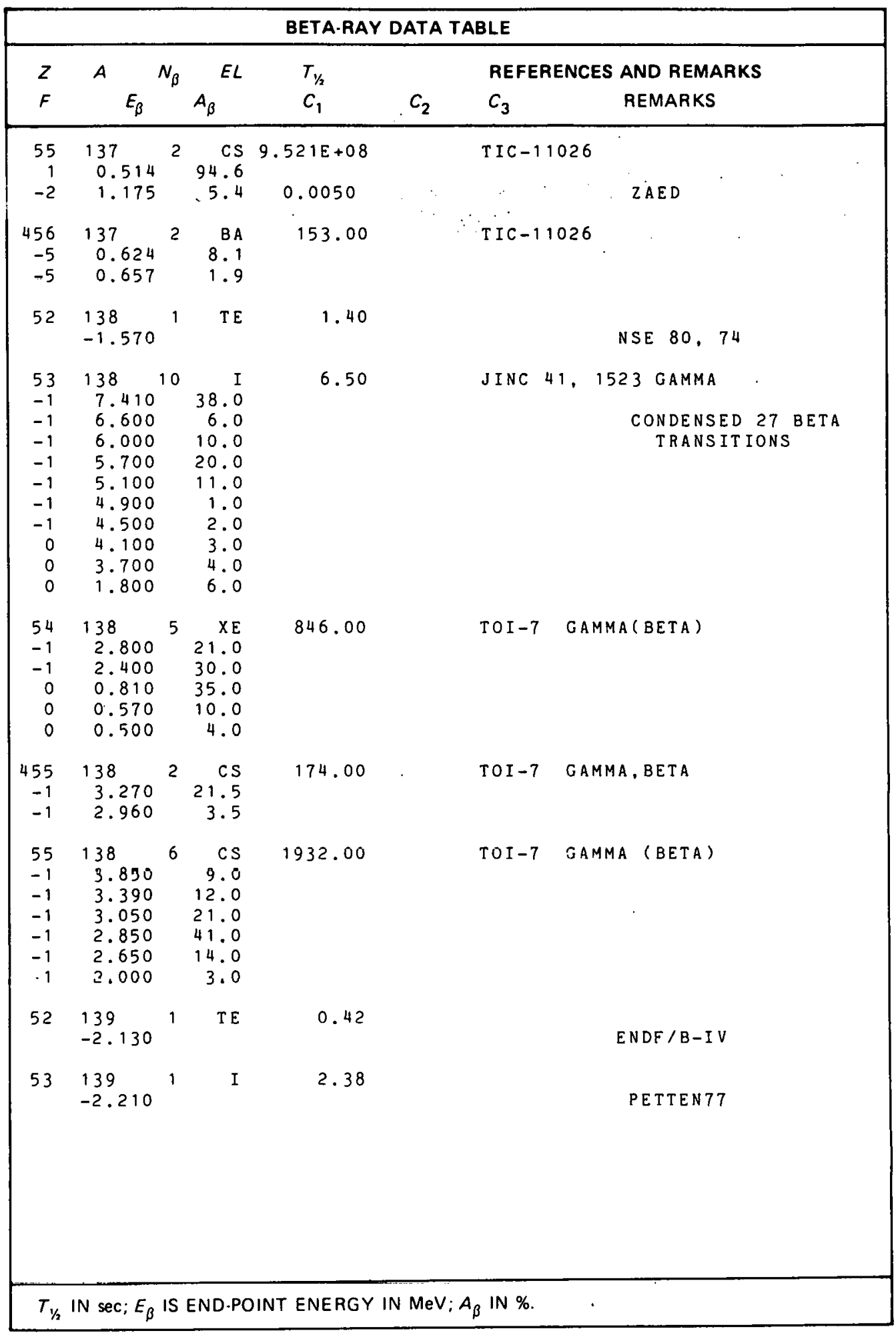

TX-5142

(7-13-82) 


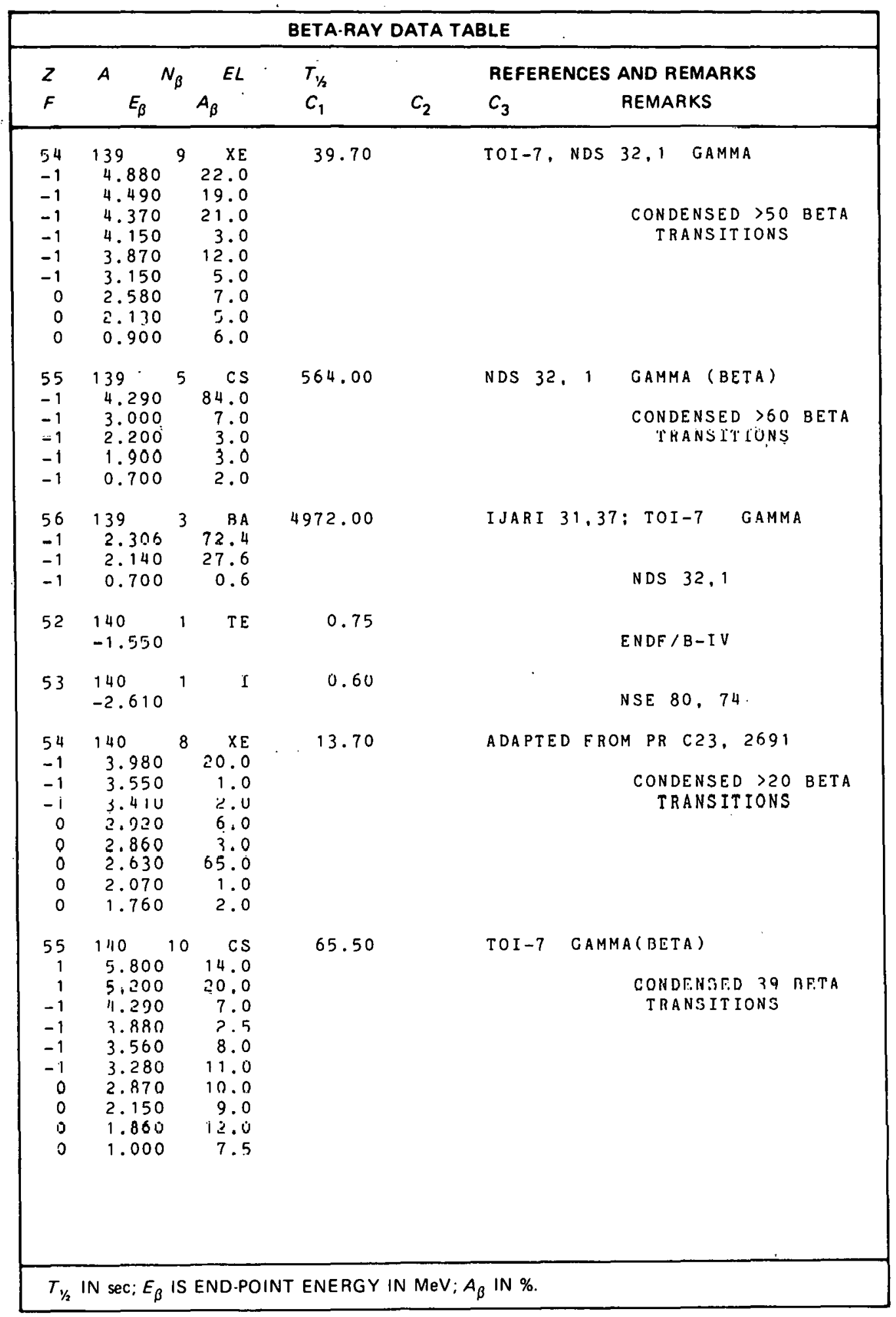

TX -5142

(7-13-82) 


\begin{tabular}{|c|c|c|c|c|c|}
\hline \multirow{3}{*}{$\begin{array}{l}Z \\
F\end{array}$} & \multicolumn{5}{|c|}{ BETA-RAY DATA TABLE } \\
\hline & $A$ & $E L$ & $T_{1 / 2}$ & REFERENCES A & AND REMARKS \\
\hline & $E_{\beta}$ & $A_{\beta}$ & $c_{2}$ & $c_{3}$ & REMARKS \\
\hline $\begin{array}{r}56 \\
1 \\
-1 \\
1 \\
-1 \\
-1\end{array}$ & $\begin{array}{l}140 \\
1.005 \\
0.991 \\
0.873 \\
0.567 \\
0.454\end{array}$ & $\begin{array}{r}5 \quad B A \\
22.0 \\
40.0 \\
4.0 \\
10.0 \\
24.0\end{array}$ & $1.105 E+06$ & TOI-7 GAMMA & $\begin{array}{c}\text { A }(\mathrm{BETA}) \\
\vdots\end{array}$ \\
\hline $\begin{array}{r}57 \\
-1 \\
-1 \\
-1 \\
-1 \\
1 \\
1 \\
-1 \\
1 \\
-5 \\
-5\end{array}$ & $\begin{array}{l}140 \\
2.164 \\
1.167 \\
1.413 \\
1.348 \\
1.300 \\
1.280 \\
1.240 \\
1.210 \\
0.450 \\
0.300\end{array}$ & $\begin{array}{r}\text { LA } \\
5.2 \\
20.7 \\
5.1 \\
44.5 \\
5.6 \\
1.2 \\
17.0 \\
0.6 \\
0.5 \\
0.9\end{array}$ & $\begin{array}{l}144972.00 \\
-0.2600 \quad 0.0\end{array}$ & $\begin{array}{l}\text { TIC }-11026 \\
0.039\end{array}$ & $\begin{array}{l}\text { RMP } 40,653 \\
\text { CONDENSED } 14 \text { BETA } \\
\text { TRANSITIONS }\end{array}$ \\
\hline 53 & $\begin{array}{l}141 \\
-2.230\end{array}$ & 1 & 0.48 & & NSE 80,74 \\
\hline $\begin{array}{r}54 \\
0 \\
-1 \\
0 \\
0 \\
0 \\
0 \\
0 \\
0\end{array}$ & $\begin{array}{l}141 \\
6.000 \\
5.450 \\
4.900 \\
4.400 \\
4.000 \\
3.300 \\
2.200 \\
1.500\end{array}$ & $\begin{array}{r}8 \quad X E \\
49.2 \\
1.5 \\
27.8 \\
9.8 \\
2.4 \\
5.2 \\
3.3 \\
0.8\end{array}$ & 1.73 & NDS 23,529 & $\begin{array}{l}\text { GAMMA } \\
\text { CONDENSED } 32 \text { BETA } \\
\text { TRANSITIONS }\end{array}$ \\
\hline $\begin{array}{l}55 \\
-1 \\
-1 \\
-1 \\
-1 \\
-1 \\
0 \\
0\end{array}$ & $\begin{array}{l}141 \\
4.980 \\
4.430 \\
3.730 \\
3.100 \\
2.200 \\
1.400 \\
0.600\end{array}$ & $\begin{array}{r}\text { CS } \\
59.0 \\
10.0 \\
12.0 \\
2.0 \\
5.0 \\
6.0 \\
6.0\end{array}$ & 24.90 & NDS 23.529 & $\begin{array}{l}\text { GAMMA (BETA) } \\
\text { CONDENSED } 45 \text { BETA } \\
\text { TRANSITIONS }\end{array}$ \\
\hline $\begin{array}{r}56 \\
1 \\
-1 \\
-1 \\
-1 \\
-1 \\
0\end{array}$ & $\begin{array}{l}141 \\
3.030 \\
2.840 \\
2.570 \\
2.380 \\
2.000 \\
1.200\end{array}$ & $\begin{array}{r}6 \quad B A \\
4.0 \\
12.0 \\
18.0 \\
23.0 \\
25.0 \\
18.0\end{array}$ & 1096.00 & NDS 23,529 & $\begin{array}{l}\text { GAMMA } \\
\text { CONDENSED } 26 \text { BETA } \\
\text { TRANSITIONS }\end{array}$ \\
\hline $\begin{array}{l}57 \\
-1 \\
-1 \\
-2\end{array}$ & $\begin{array}{l}141 \\
2.430 \\
1.080 \\
0.740\end{array}$ & $\begin{array}{r}3 \quad \text { LA } \\
98.0 \\
1.6 \\
0.11\end{array}$ & 14040.00 & NDS 23,529 & $\begin{array}{l}\text { GAMMA, BETA } \\
\text { COMM-141 }\end{array}$ \\
\hline
\end{tabular}

$\mathrm{TX}-5142$

(7-13-82) 


\begin{tabular}{|c|c|c|c|c|c|c|c|}
\hline \multicolumn{8}{|c|}{ BETA-RAY DATA TABLE } \\
\hline \multirow{2}{*}{$\begin{array}{l}Z \\
F\end{array}$} & \multirow{2}{*}{$\begin{array}{ll}A & \\
& E_{\beta}\end{array}$} & \multirow{2}{*}{$N_{\beta}$} & \multirow{2}{*}{$A_{\beta} E L$} & \multirow{2}{*}{$\begin{array}{l}T_{1 / 2} \\
C_{1}\end{array}$} & \multicolumn{3}{|c|}{ REFERENCES AND REMARKS } \\
\hline & & & & & $c_{2}$ & $c_{3}$ & REMARKS \\
\hline $\begin{array}{l}58 \\
-1 \\
-1 \\
-5 \\
-5\end{array}$ & $\begin{array}{l}141 \\
0.582 \\
0.437 \\
0.140 \\
0.100\end{array}$ & 4 & $\begin{array}{r}C E \\
30.0 \\
70.0 \\
3.3 \\
18.6\end{array}$ & $\begin{array}{c}2: 812 E+06 \\
-0.2800 \\
-0.1400\end{array}$ & & NDS 23.529 & $\begin{array}{l}\text { GAMMA, BETA } \\
\text { ZAED } \\
\text { ZAED }\end{array}$ \\
\hline 53 & $\begin{array}{l}142 \\
-2.790\end{array}$ & 1 & I & 0.20 & & . & ENDF / B - IV \\
\hline 54 & $\begin{array}{l}142 \\
-1.350\end{array}$ & 1 & $X E$ & 1.24 & & & NSE 80,74 \\
\hline $\begin{array}{r}55 \\
-1 \\
-1 \\
0 \\
0 \\
0\end{array}$ & $\begin{array}{l}142 \\
7.330 \\
6.000 \\
4.830 \\
4.190 \\
3.760\end{array}$ & 5 & $\begin{array}{r}\text { CS } \\
25.0 \\
12.0 \\
35.0 \\
18.0 \\
10.0\end{array}$ & 1.69 & & COMM-142 & \\
\hline $\begin{array}{l}5 \hbar \\
-1 \\
-1 \\
-1 \\
-1 \\
0 \\
0 \\
0\end{array}$ & $\begin{array}{l}142 \\
2.122 \\
1.940 \\
1.780 \\
1.400 \\
1.120 \\
1.000 \\
0.740\end{array}$ & $\begin{array}{l}7 \\
7 \\
7\end{array}$ & $\begin{array}{r}\text { BA } \\
6.0 \\
3.0 \\
10.0 \\
2.0 \\
20.0 \\
45.0 \\
14.0\end{array}$ & 642.00 & & TOI-7 GAMM & $\begin{array}{l}\text { A (BETA) } \\
\text { CONDENSED } 13 \text { BETA } \\
\text { TRANSITIONS }\end{array}$ \\
\hline $\begin{array}{r}57 \\
1 \\
-1 \\
-1 \\
-1 \\
-1 \\
-1 \\
-1 \\
-1 \\
-1 \\
0\end{array}$ & $\begin{array}{l}11.2 \\
4.517 \\
3.876 \\
2.900 \\
2.300 \\
2.120 \\
1.970 \\
1.820 \\
1.050 \\
0.890 \\
0.470\end{array}$ & 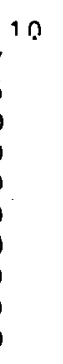 & $\begin{array}{r}1.1 \\
7.0 \\
5.0 \\
4.0 \\
9.0 \\
24.0 \\
20.0 \\
14.0 \\
5.0 \\
10.0 \\
2.0\end{array}$ & $555 n . n n$ & & TTC: $=11 \cap 26$ & $\begin{array}{l}\text { CONDENSED } 25 \text { BETA } \\
\text { TRANSTTTONS }\end{array}$ \\
\hline $\begin{array}{r}59 \\
1 \\
-1\end{array}$ & $\begin{array}{l}142 \\
2.159 \\
0.583\end{array}$ & 2 & $\begin{array}{r}P R \\
96.3 \\
3.7\end{array}$ & 68868.00 & & T IC -11026 & \\
\hline 54 & $\begin{array}{l}143 \\
-2.010\end{array}$ & 1 & $\mathrm{XE}$ & 0.30 & & & NSE 80,74 \\
\hline
\end{tabular}

TX -5142

(7-13-82) 


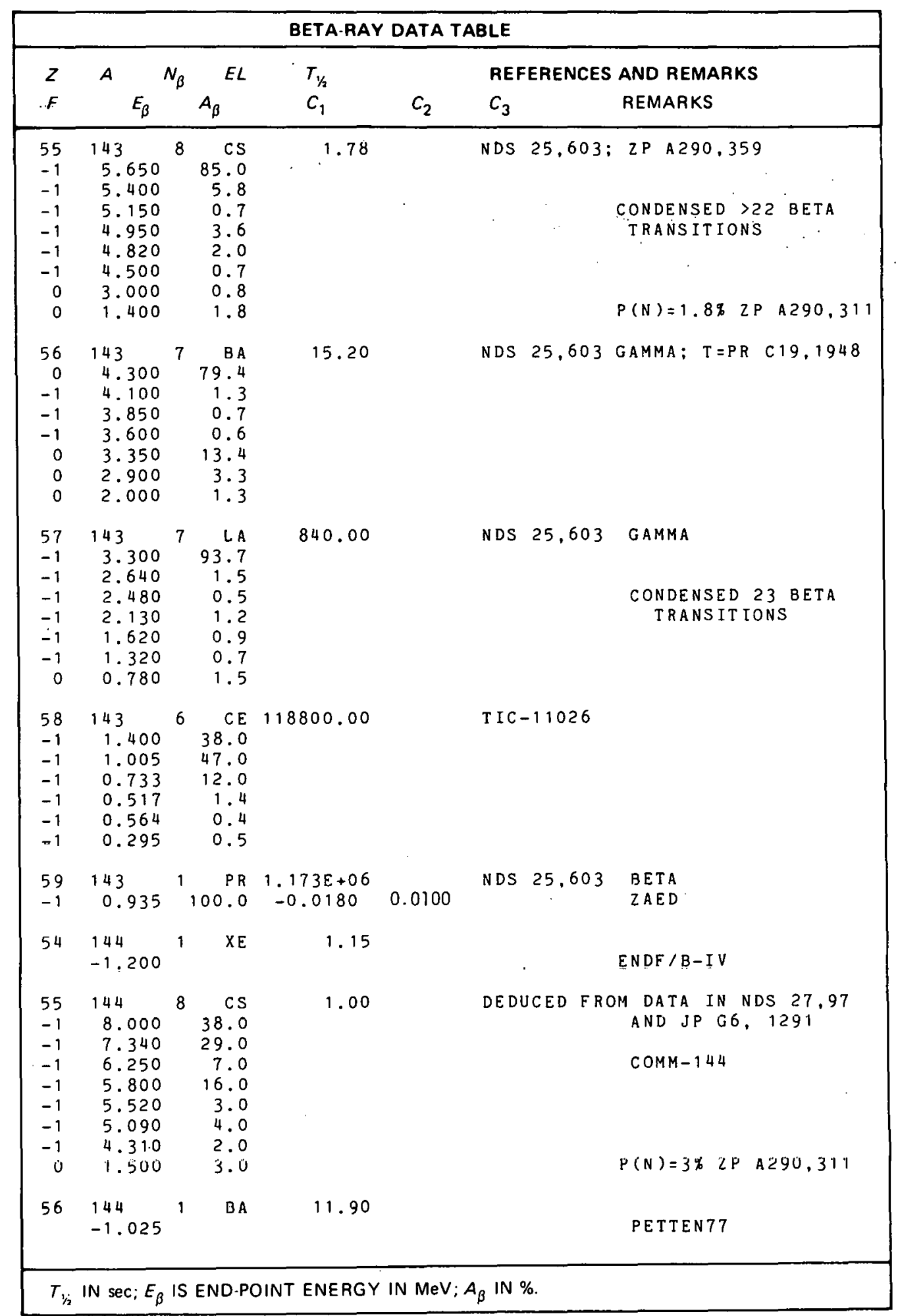

TX-5142

(7-13-82) 


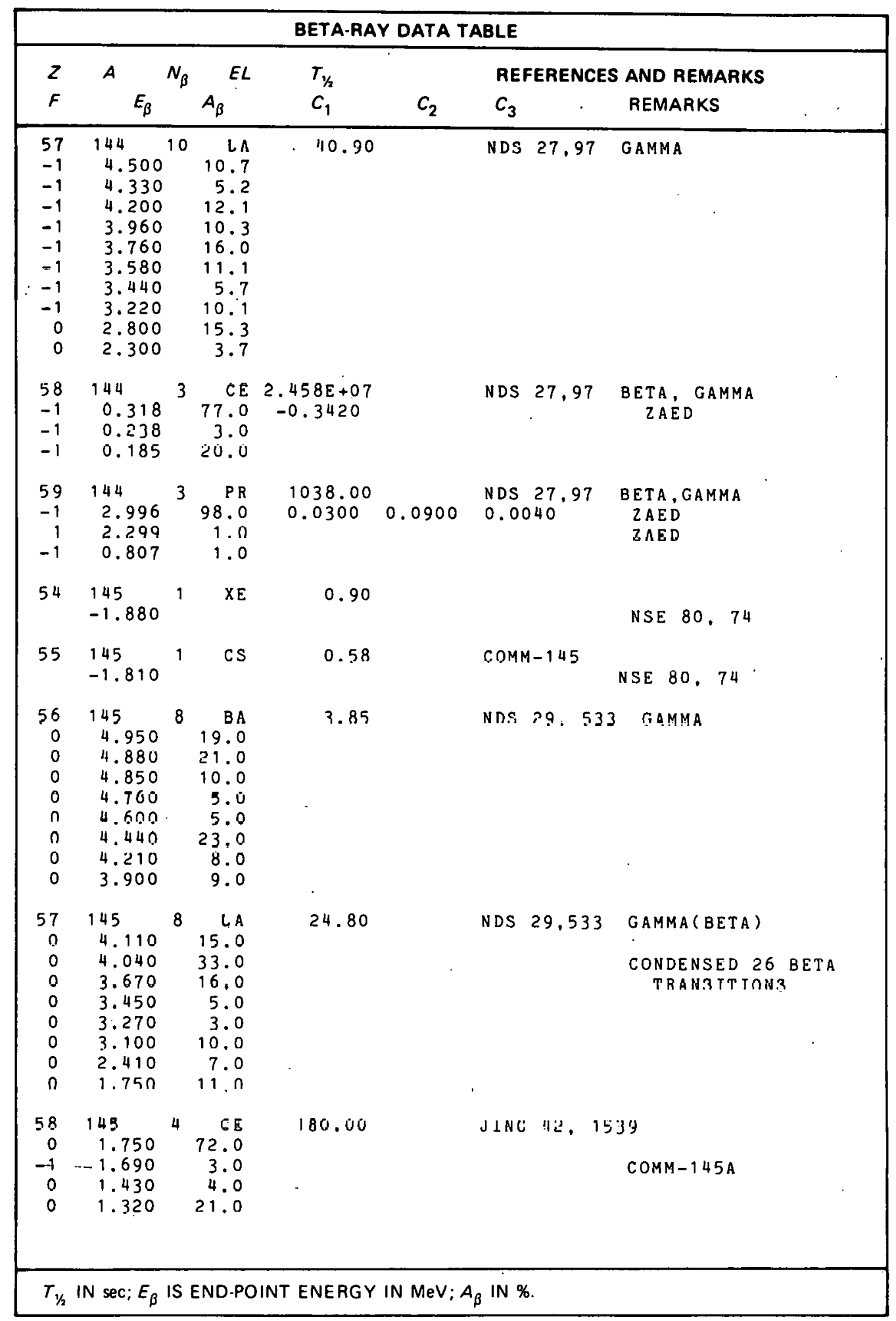




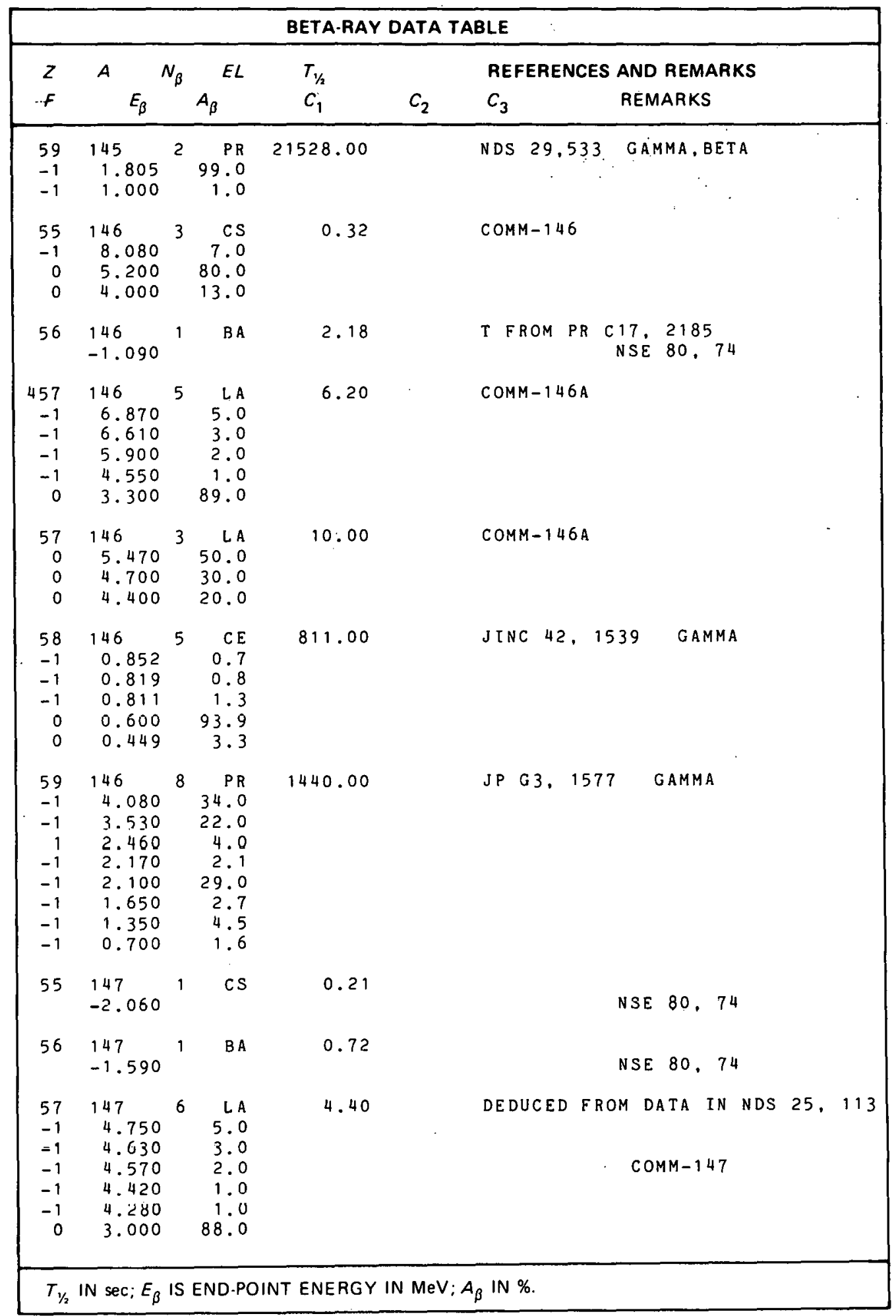

TX-5142

(7-13-82) 


\begin{tabular}{|c|c|c|c|c|c|c|}
\hline \multicolumn{7}{|c|}{ BETA-RAY DATA TABLE } \\
\hline$Z$ & $A$ & $N_{\beta}$ & $T_{1 / 2}$ & & REFERENCES AND REMARKS & \\
\hline$F$ & $E_{\beta}$ & $A_{\beta}$ & $c_{1}$ & $c_{2}$ & REMARKS & \\
\hline $\begin{array}{r}58 \\
-1 \\
-1 \\
-1 \\
0\end{array}$ & $\begin{array}{l}147 \\
3.310 \\
3.220 \\
2.950 \\
2.100\end{array}$ & $\begin{array}{rr}4 & C E \\
10.0 \\
10.0 \\
0.0 \\
0 \\
72.0\end{array}$ & 56.40 & & $\begin{array}{c}\text { DEDUCED FROM DATA IN NDS } \\
\text { COMM }-147 \mathrm{~A}\end{array}$ & 25,113 \\
\hline $\begin{array}{l}59 \\
-1 \\
-1 \\
-1 \\
-1 \\
-1 \\
-1 \\
0\end{array}$ & $\begin{array}{l}147 \\
2.700 \\
2.390 \\
2.220 \\
1.930 \\
1.390 \\
1.100 \\
0.500\end{array}$ & $\begin{array}{rr}7 & P R \\
0 & 5.0 \\
0 & 17.0 \\
0 & 6.0 \\
0 & 50.0 \\
0 & 17.0 \\
0 & 4.0 \\
0 & 1.0\end{array}$ & 819.00 & & TOI -7 GAMMA (BETA) & \\
\hline $\begin{array}{l}60 \\
-1 \\
-1 \\
-1 \\
-1 \\
-1\end{array}$ & $\begin{array}{l}147 \\
0.806 \\
0.485 \\
0.406 \\
0.360 \\
0.211\end{array}$ & \begin{tabular}{|r}
5 \\
81.0 \\
0.6 \\
0.8 \\
0.8 \\
15.3 \\
2.3
\end{tabular} & $\begin{array}{l}950400.00 \\
-0.1000 \\
-0.1000\end{array}$ & & $\begin{array}{c}\text { NDS } 25,113 \text { \ND NP A } 321, \\
\text { ZAED } \\
\text { ZAED }\end{array}$ & 341 \\
\hline $\begin{array}{l}61 \\
-1\end{array}$ & $\begin{array}{l}147 \\
0.225\end{array}$ & $\begin{array}{r}1 \quad P M \\
100.0\end{array}$ & $8.279 E+07$ & & TOI -7 BETA & \\
\hline 56 & $\begin{array}{l}148 \\
-1.070\end{array}$ & 1 & 0.47 & & NSE 80,74 & \\
\hline 57 & $\begin{array}{l}118 \\
-1.850\end{array}$ & 1 & 1.19 & & NSF. $8 \cap .74$ & \\
\hline 58 & $\begin{array}{l}148 \\
-0.540\end{array}$ & $1 \quad C E$ & 48.10 & & NSE 80,74 & \\
\hline $\begin{array}{r}459 \\
0 \\
0 \\
-1 \\
0 \\
0\end{array}$ & $\begin{array}{r}148 \\
4.050 \\
3.800 \\
3.500 \\
3.100 \\
2.900\end{array}$ & $\begin{array}{rr}5 & P R \\
0 & 44.0 \\
& 44.0 \\
0 & 0.9 \\
0 & 1.6 \\
0 & 9.5\end{array}$ & 120.00 & & JPSJ 47,1039 GAMMA & \\
\hline $\begin{array}{l}59 \\
-1 \\
-1 \\
-1 \\
-1 \\
-1 \\
-1 \\
-1 \\
-1 \\
-1 \\
0\end{array}$ & $\begin{array}{l}118 \\
4.800 \\
4.500 \\
4.100 \\
3.800 \\
3.600 \\
3.300 \\
3.130 \\
2.700 \\
2.250 \\
1.800\end{array}$ & $\begin{array}{rr}10 & F \hat{k} \\
0 & 30.0 \\
0 & 31.0 \\
0 & 1.4 \\
0 & 6.6 \\
0 & 6.4 \\
0 & 2.2 \\
0 & 11.2 \\
0 & 4.8 \\
0 & 1.2 \\
0 & 5.2\end{array}$ & 136.00 & & JHSJ $4 \%, 1 \cup 3 \%$ LAMMA & \\
\hline
\end{tabular}




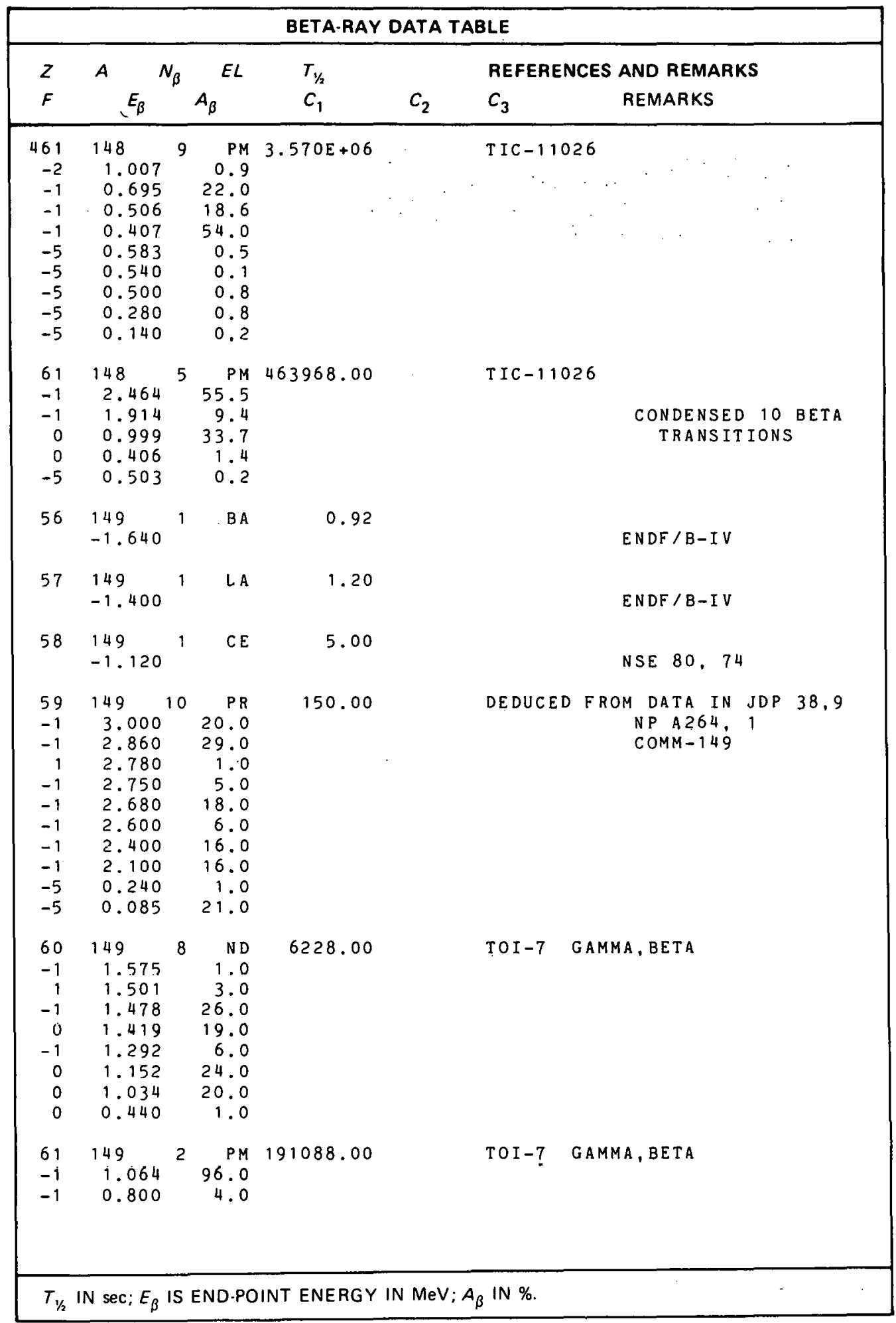

TX-5142

(7-13-82) 


\begin{tabular}{|c|c|c|c|c|c|c|c|c|}
\hline \multicolumn{8}{|c|}{ BETA-RAY DATA TABLE } & \\
\hline \multirow{3}{*}{$\underbrace{Z}_{57}$} & \multirow{3}{*}{\begin{tabular}{l}
$A \quad N$ \\
\multicolumn{1}{c}{$E_{\beta}$} \\
150 \\
-2.140
\end{tabular}} & \multirow{3}{*}{$N_{\beta}$} & \multirow{2}{*}{$A_{\beta}{ }^{E L}$} & \multirow{2}{*}{$\begin{array}{l}T_{1 / 2} \\
C_{1}\end{array}$} & \multirow[b]{2}{*}{$c_{2}$} & \multicolumn{3}{|c|}{ REFERENCES AND REMARKS } \\
\hline & & & & & & $c_{3}$ & REMARKS & \\
\hline & & & LA & 0.65 & & & ENDF / B-IV & \\
\hline 58 & $\begin{array}{l}150 \\
-0.700\end{array}$ & 1 & CE & 4.00 & & & NSE 80,74 & \\
\hline 59 & $\begin{array}{l}150 \\
-1.250\end{array}$ & 1 & PR & 6.20 & & & NSE 80,74 & \\
\hline $\begin{array}{l}61 \\
-1 \\
-1 \\
-1 \\
0 \\
0 \\
0 \\
0 \\
0 \\
0 \\
0\end{array}$ & $\begin{array}{l}150 \\
3.170 \\
2.760 \\
2.460 \\
2.330 \\
1.840 \\
1.5110 \\
1.430 \\
1.200 \\
0.700 \\
0.450\end{array}$ & $\begin{array}{l}10 \\
0 \\
0 \\
0 \\
0 \\
0\end{array}$ & $\begin{array}{r}P M \\
7.6 \\
1.7 \\
1.3 \\
28.7 \\
25.6 \\
6.1 \\
19.4 \\
5.5 \\
2.9 \\
1.2\end{array}$ & 9648.00 & & TOI -7 & $\begin{array}{r}\text { CONDENSED }>26 \\
\text { TRANSITIONS }\end{array}$ & BETA \\
\hline 57 & $\begin{array}{l}151 \\
-1.680\end{array}$ & 1 & LA & 0.95 & & & ENDF / B-IV & \\
\hline 58 & $\begin{array}{l}151 \\
-1.180\end{array}$ & 1 & $\mathrm{CE}$ & 1.00 & & & ENDF / B - I V & \\
\hline 59 & $\begin{array}{l}151 \\
-0.960\end{array}$ & 1 & $P R$ & 4.00 & & & NSE 80,74 & \\
\hline $\begin{array}{l}60 \\
-1 \\
-1 \\
-1 \\
-1 \\
-1 \\
-1 \\
-1 \\
0 \\
0\end{array}$ & $\begin{array}{r}151 \\
2.320 \\
2.180 \\
2.120 \\
2.010 \\
1.900 \\
1.590 \\
1.310 \\
1.140 \\
0.750\end{array}$ & $\begin{array}{l}b^{9} \\
0 \\
0 \\
0 \\
0 \\
0 \\
0 \\
0 \\
0\end{array}$ & $\begin{array}{r}\text { ND } \\
5.0 \\
10.0 \\
5.0 \\
5.0 \\
8.0 \\
30.0 \\
6.0 \\
24.0 \\
7.0\end{array}$ & 744.00 & & TOI -7 & GAMMA (BETA) & \\
\hline $\begin{array}{r}61 \\
-1 \\
-1 \\
-1 \\
0 \\
0\end{array}$ & $\begin{array}{l}151 \\
1.100 \\
1.020 \\
0.840 \\
0.740 \\
0.310\end{array}$ & $\begin{array}{l}5 \\
0 \\
0 \\
0 \\
0 \\
0\end{array}$ & $\begin{array}{r}\text { PM } \\
20.0 \\
12.0 \\
49.0 \\
9.0 \\
10.0\end{array}$ & 102240.00 & & $T O I-7$ & $\begin{array}{l}\text { GAMMA } \\
\text { CONDENSED } 31 \\
\text { TRANSITIONS }\end{array}$ & BETA \\
\hline $\begin{array}{l}62 \\
-1\end{array}$ & $\begin{array}{l}151 \\
0.076\end{array}$ & $5^{1}$ & 100.0 & $\begin{array}{c}2.745 F+09 \\
.\end{array}$ & & TOT -7 & BETA & \\
\hline 58 & $\begin{array}{l}152 \\
-0.794\end{array}$ & 1 & $C E$ & 7.66 & & & ENDF / B - I V & \\
\hline
\end{tabular}

$T X-5142$

(7-13-82) 


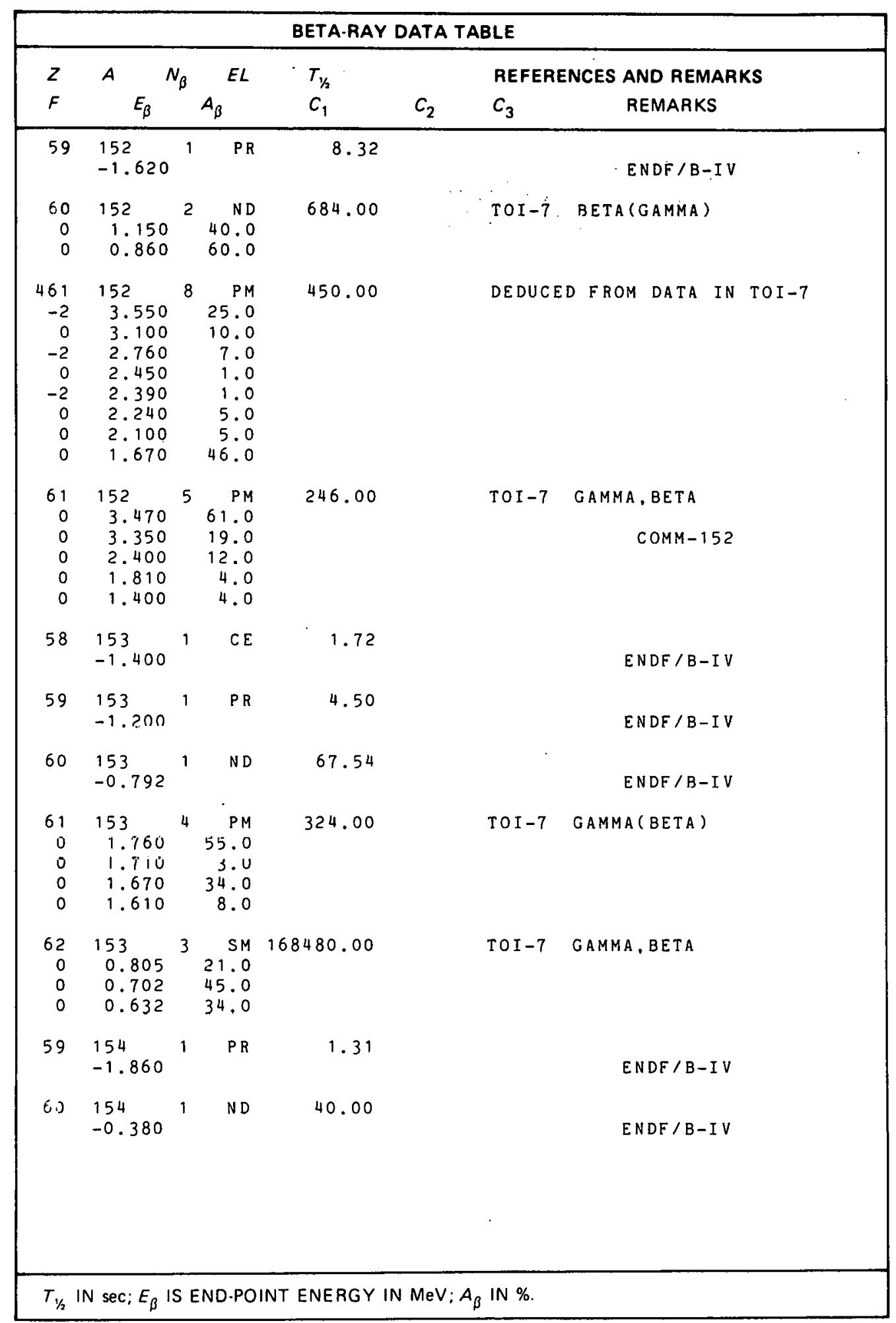

TX -5142

(7-13-82) 


\begin{tabular}{|c|c|c|c|c|c|c|}
\hline \multicolumn{7}{|c|}{ BETA-RAY DATA TABLE } \\
\hline \multirow{2}{*}{$\begin{array}{l}Z \\
F\end{array}$} & \multirow{2}{*}{$E_{\beta}{ }^{N}$} & \multirow[t]{2}{*}{$N_{\beta}$} & \multirow{2}{*}{$A_{\beta}^{E L}$} & \multirow{2}{*}{$\begin{array}{l}T_{1 / 2} \\
C_{1}\end{array}$} & \multicolumn{2}{|c|}{ REFERENCES AND REMARKS } \\
\hline & & & & & $c_{3}$ & REMARKS \\
\hline $\begin{array}{r}461 \\
0 \\
0 \\
0 \\
0 \\
0 \\
0\end{array}$ & $\begin{array}{l}154 \\
2.600 \\
2.460 \\
2.300 \\
2.150 \\
2.050 \\
1.630\end{array}$ & 6 & $\begin{array}{r}P M \\
10.0 \\
8.0 \\
21.0 \\
12.0 \\
36.0 \\
13.0\end{array}$ & 165.00 & TOI -7 & GAMMA (BETA) \\
\hline $\begin{array}{r}61 \\
0 \\
0 \\
0 \\
0 \\
0 \\
0 \\
0\end{array}$ & $\begin{array}{l}154 \\
3.080 \\
2.880 \\
2.520 \\
2.110 \\
1.910 \\
1.650 \\
1.400\end{array}$ & 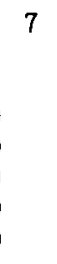 & $\begin{array}{r}P M \\
12.0 \\
9.0 \\
11.0 \\
3.0 \\
60.0 \\
1.0 \\
4.0\end{array}$ & 102.00 & TOI -7 & GAMMA (BETA) \\
\hline $\begin{array}{r}63 \\
-1 \\
-1 \\
-1 \\
-1 \\
-1 \\
0 \\
0 \\
0 \\
0 \\
-5\end{array}$ & $\begin{array}{l}154 \\
1.844 \\
1.596 \\
0.971 \\
0.839 \\
0.710 \\
0.569 \\
0.425 \\
0.340 \\
0.247 \\
0.119\end{array}$ & 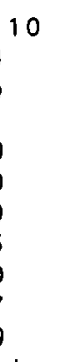 & $\begin{array}{r}. E U \\
11.4 \\
0.3 \\
2.3 \\
17.5 \\
0.9 \\
36.7 \\
0.4 \\
2.5 \\
27.9 \\
21.8\end{array}$ & $\begin{array}{l}2.760 E+08 \\
-0.2100 \quad 0.00\end{array}$ & $\begin{array}{l}\text { TIC-11 } \\
0.035\end{array}$ & $\begin{array}{l}\text { RMP } 40,659 \\
\text { CONDENSED } 24 \text { BETA } \\
\text { TRANSITIONS }\end{array}$ \\
\hline 59 & $\begin{array}{l}155 \\
-1.450\end{array}$ & 1 & PR & 1.89 & & ENDF / R - IV \\
\hline Go & $\begin{array}{l}155 \\
-0.934\end{array}$ & 1 & ND & $\varepsilon 6.06$ & & ENDE / B-IV \\
\hline 61 & $\begin{array}{l}155 \\
-0.747\end{array}$ & 1 & PM & 36.56 & & ENDF/B-IV \\
\hline $\begin{array}{r}62 \\
0 \\
-1 \\
-1\end{array}$ & $\begin{array}{l}155 \\
1.525 \\
1.384 \\
1.322\end{array}$ & 3 & $\begin{array}{r}\text { SM } \\
93.2 \\
4.3 \\
2.2\end{array}$ & 1332.00 & IOI -7 & GAMMA ( BETA) \\
\hline $\begin{array}{l}63 \\
-1 \\
-1\end{array}$ & $\begin{array}{l}155 \\
0.246 \\
0.140\end{array}$ & $b^{2}$ & $\begin{array}{r}E U \\
13.0 \\
87.0\end{array}$ & $1.565 E+08$ & TOI -7 & GAMMA, BETA \\
\hline 60 & $\begin{array}{l}156 \\
=0.594\end{array}$ & 1 & ND & 19.60 & & ENDF / B-IV \\
\hline 61 & $\begin{array}{l}156 \\
-1.270\end{array}$ & 1 & $P M$ & 13.10 & & ENDF / B-IV \\
\hline$T_{1 / 2}$ & $\sec ; E_{\beta}$ & . & D.PO & IT ENERGY IN & $A_{\beta}$ IN $\%$. & \\
\hline
\end{tabular}




\begin{tabular}{|c|c|c|c|c|c|c|c|}
\hline \multicolumn{8}{|c|}{ BETA-RAY DATA TABLE } \\
\hline \multirow{2}{*}{$\begin{array}{l}Z \\
F\end{array}$} & \multirow{2}{*}{$\begin{array}{l}A \quad \\
E_{\beta}\end{array}$} & \multirow[t]{2}{*}{$N_{\beta}$} & \multirow{2}{*}{$A_{\beta}{ }^{E L}$} & \multirow{2}{*}{$\begin{array}{l}T_{1 / 2} \\
c_{1}\end{array}$} & \multirow[b]{2}{*}{$c_{2}$} & \multicolumn{2}{|c|}{ REFERENCES AND REMARKS } \\
\hline & & & & & & $c_{3}$ & REMARKS \\
\hline $\begin{array}{r}62 \\
0 \\
0\end{array}$ & $\begin{array}{l}156 \\
0.692 \\
0.423\end{array}$ & 2 & $\begin{array}{r}S M \\
55.0 \\
45.0\end{array}$ & 33840.00 & & IP $G 7$ & $\begin{array}{l}837 \\
.\end{array}$ \\
\hline $\begin{array}{r}63 \\
-1 \\
-1 \\
-1 \\
-1 \\
0 \\
-1 \\
-1 \\
0\end{array}$ & $\begin{array}{l}156 \\
2.453 \\
1.403 \\
1.250 \\
1.117 \\
0.487 \\
0.430 \\
0.266 \\
0.180\end{array}$ & 8 & $\begin{array}{r}E U \\
31.0 \\
1.4 \\
9.5 \\
2.3 \\
30.0 \\
6.0 \\
14.0 \\
5.8\end{array}$ & $1.306 \mathrm{E}+06$ & & TOI -7 & GAMMA, BETA \\
\hline 60 & $\begin{array}{l}157 \\
-1.160\end{array}$ & 1 & ND & 4.15 & & & $E N D F / B-I V$ \\
\hline 61 & $\begin{array}{l}157 \\
-0.977\end{array}$ & 1 & PM & 5.00 & & & ENDF / B-IV \\
\hline $\begin{array}{r}62 \\
0 \\
0 \\
0 \\
0 \\
0\end{array}$ & $\begin{array}{l}157 \\
2.400 \\
2.200 \\
2.100 \\
1.700 \\
1.100\end{array}$ & 5 & $\begin{array}{r}S M \\
53.0 \\
37.0 \\
3.0 \\
2.0 \\
5.0\end{array}$ & 486.00 & & A DAPTED & $\begin{array}{c}\text { FROM JINC } 42,1547 \\
\text { COMM }-157\end{array}$ \\
\hline $\begin{array}{r}63 \\
0 \\
-1 \\
-1 \\
0 \\
-1 \\
-1\end{array}$ & $\begin{array}{l}157 \\
1.300 \\
1.240 \\
0.930 \\
0.890 \\
0.840 \\
0.680\end{array}$ & 6 & $\begin{array}{r}E U \\
41.0 \\
9.0 \\
15.0 \\
22.0 \\
5.0 \\
7.0\end{array}$ & 54468.00 & & TOI -7 & GAMMA \\
\hline 61 & $\begin{array}{l}158 \\
-1.590\end{array}$ & 1 & PM & 3.80 & & & ENDF/B-IV \\
\hline 62 & $\begin{array}{l}158 \\
-0.241\end{array}$ & 1 & SM & 331.00 & & I FROM & 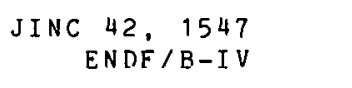 \\
\hline $\begin{array}{r}63 \\
-1 \\
0 \\
-1 \\
-1 \\
-1 \\
-1 \\
0 \\
-1\end{array}$ & $\begin{array}{l}150 \\
3.400 \\
2.450 \\
2.150 \\
1.600 \\
1.450 \\
1.400 \\
1.100 \\
0.950\end{array}$ & $\theta$ & $\begin{array}{r}E U \\
5.0 \\
50.0 \\
6.0 \\
11.0 \\
15.0 \\
4.0 \\
6.0 \\
3.0\end{array}$ & 2754.00 & . & TOI -7 & GAMMA, BETA \\
\hline 61 & $\begin{array}{l}159 \\
-1.260\end{array}$ & 1 & PM & 4.23 & & & ENDF / B - I V \\
\hline
\end{tabular}

TX-5142

(7-13-82) 


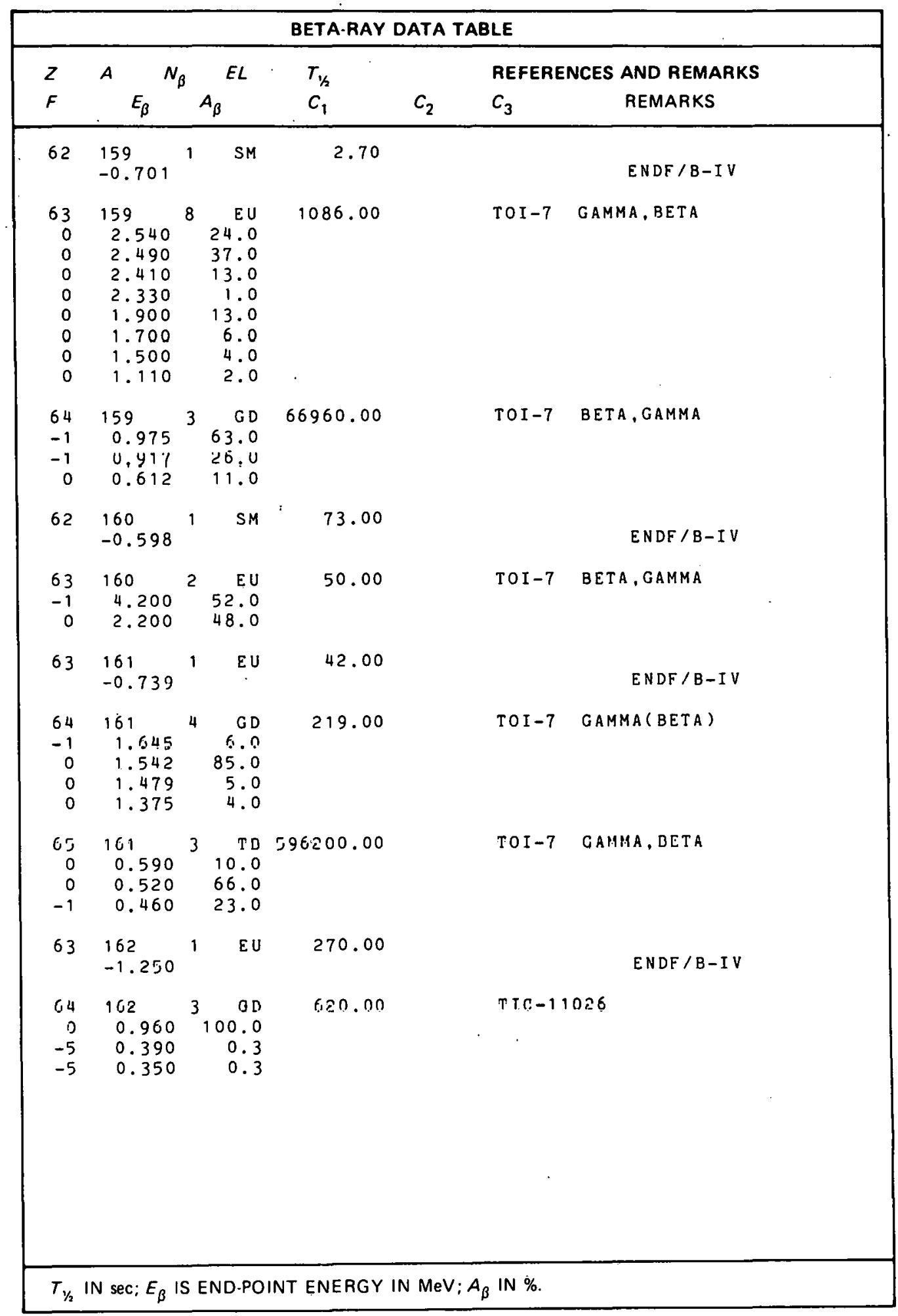

$T X-5142$

(7-13-82) 


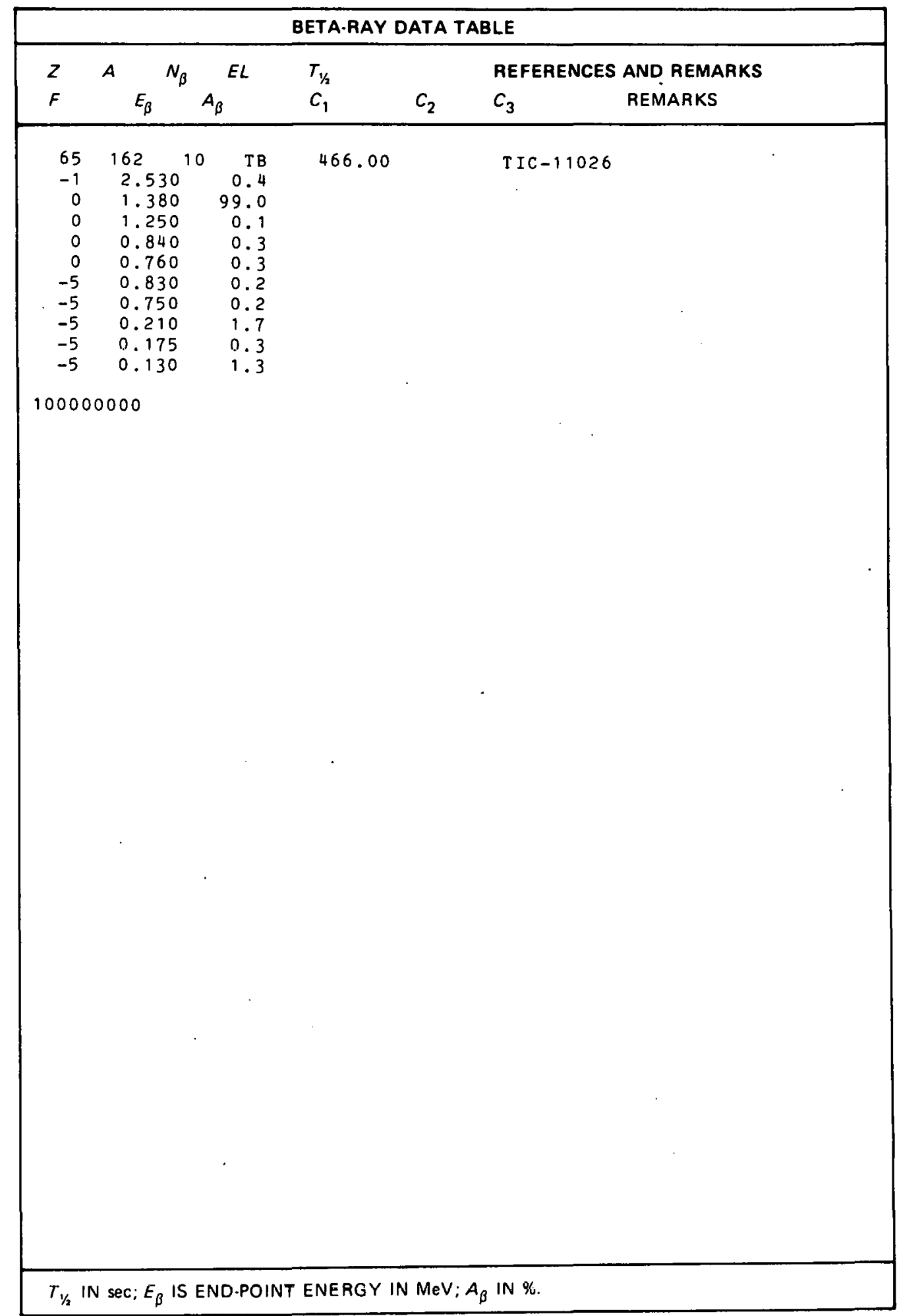

$T X-5142$

(7-13-82) 


\section{DATA TABLE REFERENCES AND FOOTNOTES}

ADNDT 19, 177 A. H. Wapstra and K. Bos, At. Data and Nucl. Data Tables 19, 117 (1977).

ADNDT 19, 419 E. A. C. Crouch, At. Data and Nucl. Data Tables 19, 419 (1977).

BNL-29694 R. L. Gill, R. E. Chrien, M. Shmid, G. M. Gowdy, H. J. Liou, D. S. Brenner, F. K. Wohn, K. Sistemich, H. Yamamoto, C. Chung, and W. B. Walters, "Band Structure in ${ }^{148} \mathrm{Ce}$ from the Decay of Mass-Separated ${ }^{148} \mathrm{La}$," Brookhaven National Lahoratory Report No. BNL-29694 (1981).

COMM-78 $\quad \mathrm{A}_{\beta}$ normalized to give $\Sigma \mathrm{A}_{\beta}=100 \%$.

COMM-80 $\quad A_{\beta}$ consistent wlth NP A368, 210; low-energy group added to give $\left\langle E_{\beta}\right\rangle$ consistent with NSE 80, 74.

COMM-82 Some information is available in NP A368, 210.

COMM-84 In ENDF/B-IV, tabulated $\left\langle\mathrm{E}_{\beta}\right\rangle$ includes the energy contributed by delayedneutron emission; as much as possible the delayed-neutron energies, $\left\langle E_{n}\right\rangle$, for 27 fission products are given in RUD79. The labulated $\left\langle E_{n}\right\rangle$ àre approxımately related to the available energy for neutron emission by $\left\langle E_{n}\right\rangle=0.19\left(Q_{\beta}-B_{n}\right)^{0.7}$. $P_{n}$ values are needed to estimate the energy contributed by dclayed-neutron emission, and these were obtained from RUD77 or else estimated from the approximate methods of ZP 263, 435. $Q_{\beta}$ and $B_{n}$ values were obtained from ADNDT 19, 177 when available, otherwise from ENDF/B-IV. Most corrcctions to listed $\left\langle\mathrm{E}_{\beta}\right\rangle$ are less than $0.1 \mathrm{MeV}$. The largest corrections are for ${ }^{84} \mathrm{Ga}(0.71),{ }^{87} \mathrm{Ge}(0.31),{ }^{89} \mathrm{As}$ $(0.46),{ }^{93} \mathrm{Br}(0.32),{ }^{95} \mathrm{Br}(0.97)$, and ${ }^{133} \mathrm{In}(0.41)$, where the number in parentheses is the computed total neutron energy, $P_{n}$ times $\left\langle E_{n}\right\rangle$, in $\mathrm{MeV}$.

COMM-87 Some information is available in JINC 42, 1387. 
COMM-89 Reapportioned unplaced $\mathrm{A}_{\gamma}$ (of 6.6\%) among four groups given by $\mathrm{E}_{\beta}=3.9,4.8$, 6.0 , and $6.5 \mathrm{MeV}$ to preserve intensity totals.

COMM-89A $\quad J^{\pi}$ of ground state of ${ }^{89} \mathrm{Kr}$ assumed $5 / 2^{+}$, i.e., $53 \mathrm{~d}$ neutron in $\mathrm{d}_{5 / 2}$ shell. See $\mathrm{J}^{\pi}$ for ${ }^{87} \mathrm{Kr}$ and ${ }^{91} \mathrm{Se}$.

COMM-90 Reapportioned unplaced $\mathrm{A}_{\gamma}$ (of 5.4\%) to preserve intensity totals.

COMM-94 For ${ }^{94} \mathrm{Y}, \mathrm{A}_{\gamma}\left(\mathrm{E}_{\gamma}=0.919 \mathrm{MeV}\right)$ of $(56 \pm 3) \%$ by RRL 21,151 is likely too large. More recently PR C22, 152 uses $(49 \pm 2) \%$. Analysis of ${ }^{235} \mathrm{U}$ fission-product beta-ray data of NUREG-39 by PRL 46, 1061 as well as study of ${ }^{245} \mathrm{Cm}\left(\mathrm{n}_{\text {thermal }}, \mathrm{f}\right)$ yields by PR C23, 331 supports an $\mathrm{A}_{\gamma}$ of $44 \%$, in agreement with earliest measurements of this $\mathrm{A}_{\gamma}$ by JINC 10, 183.

COMM-94A $\quad Q_{\beta}$ and known highest energy $E_{\beta}$ from ZP A294, 35; $P_{n}$ from ZP A290, 311; $B_{n}$ estimated from data in PR C19, 1504; gamma-ray data given in PR C22, 252 yield information on ${ }^{94} \mathrm{Sr}$ level structure. PR C22, 252 quotes unpublished work giving three high-energy transitions as: (1) $\mathrm{E}_{\beta}=8.4 \mathrm{MeV}, \mathrm{A}_{\beta}=7.2 \%$; (2) $\mathrm{E}_{\beta}=7.9$ $\mathrm{MeV}, \mathrm{A}_{\beta}=38 \%$; and (3) $\mathrm{E}_{\beta}=7.2 \mathrm{MeV}, \mathrm{A}_{\beta}=4.7 \%$ all deduced from gamma-ray measurements. $E_{\beta}=8.4 \mathrm{MeV}$ not observed by $\mathrm{ZP} \mathrm{A} 294,35 . \mathrm{A}_{\beta}\left(\mathrm{E}_{\beta}=7.9 \mathrm{MeV}\right)$ inconsistent with measured total $\beta$-ray spectrum of NSE 80, 74. Present assignments are best estimates of $E_{\beta}$ and $A_{\beta}$ as consistent with above references as can be deduced from these partially discrepant data.

COMM-95 $\quad \mathrm{Q}_{\beta}$ and $\mathrm{B}_{n}$ values estimated from data in PR C19, 1504; $\mathrm{P}_{n}$ from ZP A290, 311; known high-energy $E_{\beta}$ from ZP A294, 35; approximate low-energy $E_{\beta}$ from PL 86B, 21; estimated $A_{\beta}$ for high-energy beta for forbidden transition, remaining $E_{\beta}, A_{\beta}$ to give $\left\langle\mathrm{E}_{\beta}\right\rangle$ consistent with NSE 80, 74. See also ZP A273, 283 for partial decay scheme. 
$\mathrm{Q}_{\beta}$ and $\mathrm{B}_{n}$ values estimated from data in PR C19, 1504; $\mathrm{P}_{n}$ from ZP A290, 311; known high-energy $E_{\beta}$ from ZP A294, 35; estimated $A_{\beta}$ for high-energy beta rays for forbidden transitions, remaining $E_{\beta}$ and $A_{B}$ to give $\left\langle E_{\beta}\right\rangle$ consistent with NSE 80, 74. See also PR C22, 252 for partial decay scheme.

COMM-97 $\mathrm{Q}_{\beta}$ and $\mathrm{B}_{n}$ values estimated from data in PR C19, 1504; $\mathrm{P}_{n}$ from ZP A290, 311; known high-energy $E_{\beta}$ from ZP A294, 35; estimated $A_{\beta}$ for high-energy beta for forbidden transition, remaining $E_{\beta}$ and $A_{\beta}$ to give $\left\langle E_{\beta}\right\rangle$ consistent with NSE 80 , 74.

COMM-98 Data indicative of two isomers of ${ }^{98} \mathrm{Rb}$ are reported in NP A339, 415. Both isomers likely have negative parity and decay to much higher lying states than observed in reference.

COMM-100 $\mathrm{J}^{\pi}$ probably $4^{-}$to $6^{-}$.

COMM-103 $\quad A_{\beta}$ adjusted to $A_{\gamma}\left(E_{\gamma}=497 \mathrm{keV}\right)$ of IJARI 32, 573.

COMM-108 Electron capture decay of ${ }^{108} \mathrm{Ag}$ is not included.

COMM-113 Interpret statement in NDS 33, 1 that total gamma feeding to ${ }^{113} \mathrm{Pd}$ ground state is $9 \%$.

COMM-116 $\quad \mathrm{A}_{\beta}\left(\mathrm{E}_{\beta}=870 \mathrm{keV}\right)$ as given in TOI-7.

COMM-122 Electron capture decay of ${ }^{122} \mathrm{Sb}$ not included.

COMM-124 Combined decay to two states $0.1 \mathrm{MeV}$ apart.

COMM-125 Lowest energy beta-rays omitted $\left(A_{\beta}<1 \%\right)$.

COMM-126 High-spin isomers of ${ }^{126} \mathrm{In}$ and ${ }^{178} \mathrm{In}$ repurted by NP A323, 205 not included in this compilation. 
COMM-128

COMM-130

COMM-131

COMM-133

COMM-135

COMM-141

COMM-142

COMM-144

COMM-145

COMM-145A
Electron capture decay of ${ }^{128} \mathrm{I}$ not included.

NP A352, 157 postulate two isomers both having $T_{1 / 2}=0.5 \mathrm{sec}$. Until clarified, compilation will use $\left\langle\mathrm{E}_{\beta}\right\rangle$ only.

$A_{\beta}$ estimated to give about equal $\log (\mathrm{ft})$ values and give $\left\langle\mathrm{E}_{\beta}\right\rangle$ consistent with NSE 80,74 .

Assume $0 \%$ ground-state transition and $0 \%$ direct population of $15-\mathrm{m}$ isomeric level.

$E_{\beta}=5.33$ and 5.06 from ZP A289, 407. Infer $A_{\beta}(5.33 \mathrm{MeV}) \ll A_{\beta}(5.06 \mathrm{MeV})$ from data exhibited in ZP A289, 407. Add low-energy $E_{\beta}$ to adjust $\left\langle E_{\beta}\right\rangle$ consistent with NSE 80,74 . See also JDP $38,9$.

$A_{\beta}$ adjusted to $A_{\gamma}\left(E_{\gamma}=1354 \mathrm{keV}\right)$ of IJARI 32,377 .

$E_{\beta}=7.33$ and $6.00 \mathrm{MeV}$ reported by $\mathrm{ZP} \mathrm{A301,} \mathrm{165.} \mathrm{Four} E_{\beta}$ in NDS 25, 53 assumed low in energy by $\sim 10 \% . \quad \mathrm{J}^{\pi}$ of ${ }^{142} \mathrm{Cs}$ ground state probably $0^{-}$(parity seems certain). Low-energy portion of ${ }^{142} \mathrm{Ba}$ decay scheme given in JP G6, 1291. Postulate five $\beta$-ray transitions, two highest-energy are forbidden, the other three as allowed transitions. $A_{\beta}$ determined to give consistent $\log (\mathrm{ft})$ values and also to give $\left\langle\mathrm{E}_{\beta}\right\rangle$ consistent with NSE 80, 74.

$\mathrm{J}^{\pi}$ probably $1^{-}$.

$\mathrm{Q}_{\beta}$ from ZP A300, 249 is $(7.96 \pm .08) \mathrm{MeV}$, and that from ZP A301, 165 is (7.36 $\pm 0.07) \mathrm{MeV}$. This difference is much larger than comparisons of other measured (see ZP A300, 249 for comparisons) suggesting an unaccounted for error in one (or both) of these experiments for decay of ${ }^{145} \mathrm{Cs}$.

JINC 42, 1539 reports no beta rays having $E_{\beta}>1.8 \mathrm{MeV}$; ZP A299, 209 reports $18 \%$ beta rays having $2.35 \mathrm{MeV}$. Latter experiment may include contributions for other Ce isotopes. 
COMM-146 $Q_{\beta}$ is from ZP A300, 249; $B_{n}$ is from PR C19, 1504; $P_{n}$ and $T_{1 / 2}$ from ZP A290, 311; high-energy $\mathrm{E}_{\beta}$ from ZP A301, 165; $\mathrm{A}_{\beta}$ for this $\beta$-ray inferred to be weak from data shown in ZP A301, 165 consistent with first-forbidden transition directly populating the $\mathrm{J}^{\pi}=2^{+}, \mathrm{E}_{x}=1256 \mathrm{keV}$ level (JP G6, 1291). $\mathrm{E}_{\beta}$ and $\mathrm{A}_{\beta}$ for low-energy allowed transitions represents $P_{n}$ times $\left\langle E_{n}\right\rangle ; A_{\beta}\left(E_{\beta}=8.08 \mathrm{MeV}\right)$ maximum for a first-forbidden transition; $E_{\beta}$ and $A_{\beta}$ for remaining entry to give $\left\langle E_{\beta}\right\rangle$ consistent with NSE 80, 74.

COMM-146A ZP A289, 407 gives data for two isomers of ${ }^{146} \mathrm{La}$. The 10 -sec isomer is probably high-spin and not fed by decay of ${ }^{146} \mathrm{Ba}$. The three $\mathrm{E}_{\beta}$ reported are all probably allowed transitions; $A_{\beta}$ of these were adjusted to give approximately equal $\log (\mathrm{ft})$ values. Tlie G-sec isumer has $\mathrm{J}^{\pi}=1^{-}$most likely. The obscrved $\mathrm{A}_{\beta}$ arc likely weaker than inferred from the text of ZP A289, 407. The transitions are very probably forbidden. An additional low-energy transition is postulated to give $\left\langle\mathrm{E}_{\beta}\right\rangle$ consistent with NSE 80, 74.

COMM-147 Parity of ${ }^{147} \mathrm{La}$ is probably positive and parities of low-lying ${ }^{147} \mathrm{Ce}$ states are probably negative. Ubserved $\beta$-ray transitions must be forbidden. Postulate a groundstate $\beta$-ray transition, and adjusted $A_{\beta}$ to give $\log (\mathrm{ft})$ values consistent with firstforbidden transitions in this mass region. Low-energy $E_{\beta}, A_{\beta}$ to give $\left\langle E_{\beta}\right\rangle$ consistent with NSE $80,74$.

COMM-147A Three highest-energy $\beta$-ray transitions following decay of ${ }^{147} \mathrm{Ce}$ reported in ZP A285, 287 are probably forbidden since parity of ${ }^{147} \mathrm{Ce}$ ground state is probably negative while parities of low-lying ${ }^{147} \mathrm{Pr}$ states are probably positive. $\mathrm{A}_{\beta}$ for these three transitions adjusted to give $\log (\mathrm{ft})$ values consistent with first-forbidden transitions in this mass region. Low-energy $E_{\beta}$ and $A_{\beta}$ postulated to give $\left\langle E_{\beta}\right\rangle$ consistent with NSE 80, 74. 
COMM-148

COMM-149

COMM-152

COMM-157

ENDF/B-IV

IJARI 31,37

IJARI 32,377

IJARI 32, 573

JDP 38,9

JINC 10,183
$T(1 / 2)$ from unpublished work, BNL-29694. There is a proposed decay scheme in this reference. $\left\langle\mathrm{E}_{\beta}\right\rangle$ of the $\beta$-ray spectrum using this proposed decay scheme is $0.7 \mathrm{MeV}$ larger than measured $\left\langle\mathrm{E}_{\beta}\right\rangle$ of NSE $80,74$.

TOI-7 and NDS 19,337 base $A_{\beta}$ for ${ }^{149} \operatorname{Pr}$ on reported $(55 \pm 20) \%$ ground-state branching of NP A99, 473. This ground-state branching is too large according to $A_{\gamma}$ of JDP 38,9 . It appears that NP A99, 473 did not consider conversion electron contributions, which would result in a revision of the deduced ground-state beta branching to $(28 \pm 20) \%$.

15-min isomer not included in this compilation.

Assumed level structure of ${ }^{157} \mathrm{Eu}$ similar to ${ }^{155} \mathrm{Eu}$. Also assumed no ground- or first-excited-state direct beta transitions. Weak $\gamma$ rays reported by JINC 42, 1547 not placed.

Reference 19.

R. J. Gehrke, Int. J. App. Rad. Isot. 31, 37 (1980).

R. J. Gehrke, Int. J. App. Rad. Isot. 32, 377 (1981).

H. Miyahara, T. Gotoh, and T. Watanabe, Int. J. App. Rad. Isot. 32, 573 (1981).

B. Pfeiffer, J. P. Bocquet, A. Pinston, R. Roussille, M. Asghar, G. Bailleul, R. Decker, J. Greif, H. Schrader, G. Siegert, H. Wollnik, J. Blachot, E. Monnand, and F. Schussler, J. de Phys. 38, 9 (1977).

J. D. Knight, D. C. Hoffman, B. J. Dropesky and D. L. Frasco, J. Inorg. Nucl. Chem. 10, 183 (1959).

JINC 39, 1487 G. Skarnemark, P. O. Aronsson, T. Bjornstad, E. Kvale, N. Kaffrell, E. Stender, and N. Trautmann, J. Inorg. Nucl. Chem. 39, 1487 (1977). 
JINC 4I, 1523

JINC 42, 1387

JINC 42, 1539

JINC 42, 1547

JP G3, 1577

JP G6, 1291

JP G7, 837

JPSJ 47, 26

JPSJ 47, 1039

JPSJ 50, 1057

NDS 19, 337

NDS 22, 135

NDS 23, 529

NDS 25,53

NDS 25,113

NDS 25, 315
P. Hoff, J. Inorg. Nucl. Chem. 4l, 1523 (1979).

M. Zendel and N. Trautmann, J. Inorg. Nucl. Chem. 42, 1387 (1980).

H. Yamamoto, Y. Ikeda, K. Kawade, T. Katoh, and T. Nagahara, J. Inorg. Nucl. Chem. 42, 1539 (1980).

J. D. Baker, R. J. Gehrke, R. C. Greenwood, D. H. Meikrantz and V. J. Novick, J. Inorg. Nucl. Chcm. 42, 1547 (1980).

H. W. Taylor and B. Singh, J. Phys. G 3, 1577 (1977).

S. M. Scott, W. D. Hamilton, P. Hungerford, D.

D. Warner, G. Jung, K. D.

Wunsch and B. Pfeiffer, J. Phys. G 6, 1291 (1980).

G. Christopoulos, W. D. Hamilton and C. Girit, J. Phys. G 7, 837 (1981).

H. Niizeki, S. Kageyama, T. Tamura, and Z. Matumoto, J. Phys. Soc. Japan 47, 1 (1979).

Y. Ikeda, H. Yamamoto, K. Kawade, T. Takeunchi, T. Katoh, and T. Nagahara, J. Phys. Soc. Japan 47, 1039 (1979).

S. Ohya, M. Kanazawa, N. Mutsuro, T. Tamura, and Z. Matumoto, J. Phys. Soc. Japan 50, 1057 (1981).

G. E. Holland, Nucl. Data Sheets 19, 337 (1976).

F. E. Bertrand, Nucl. Data Sheets 22, 135 (1977)..

J. K. Tuli, Nucl. Data Sheets 23, 529 (1978).

J. K. Tuli, Nucl. Data Sheets 25, 53 (1978).

B. Harmatz and W. B. Ewbank, Nucl. Data Sheets 25, 113 (1978).

R. L. Auble, Nucl. Data Sheets 25, 315 (1978). 
NDS 25,553

NDS 25, 603

NDS 26, 473

NDS 27, 97

NDS 27, 339

NDS 28, 343

NDS 28, 403

NDS 29, 75

NDS 29,453

NDS 29, 533

NDS 29, 587

NDS 30, 573

NDS 31,103

NDS 31, 181

NDS 32,1

NDS 32, 211

NDS 32, 287

NDS 32, 497

NDS 33,1

NDS 33, 189
J. W. Tepel, Nucl. Data Sheets 25, 553 (1978).

J. K. Tuli, Nucl. Data Sheets 25, 603 (1978).

L. K. Peker, Nucl. Data Sheets 26, 473 (1979).

J. K. Tuli, Nucl. Data Sheets 27, 97 (1979).

H. W. Muller and J. W. Tepel, Nucl. Data Sheets 27, 339 (1979).

B. Harmatz, Nucl. Data Sheets 28, 343 (1979).

B. Harmatz, Nucl. Data Sheets 28, 403 (1979).

B. Singh and D. A. Viggars, Nucl. Data Sheets 29, 75 (1980).

T. Tamura, Z. Matumoto, K. Miyano and S. Ohya, Nucl. Data Sheets 29, 453 (1980).

J. K. Tuli, Nucl. Data Sheets 29, 533 (1980).

L. K. Peker, Nucl. Data Sheets 29, 587 (1980).

P. Luksch, Nucl. Data Sheets 30, 573 (1980).

F. Kearns and J. N. Mo, Nucl. Data Sheets 31, 103 (1980).

H. W. Muller, Nucl. Data Sheets 31, 181 (1980).

L. K. Peker, Nucl. Data Sheets 32, 1 (1981).

L. P. Ekstrom, Nucl. Data Sheets 32, 211 (1981).

J. Blachot, J. P. Husson, J. Oms, G. Marguier, and F. Haas, Nucl. Data Sheets 32, $287(1981)$

T. Tamura, Z. Matumoto and M. Ohshima, Nucl. Data Sheets 32, 497 (1981).

J. Lyttkens, K. Nilson, and L. P. Ekstrom, Nucl. Data Sheets 33, 1 (1981).

B. Singh and D. A. Viggars, Nucl. Data Sheets 33, 189 (1981). 
NIM 175, $535 \quad$ J. K. Dickens and T. A. Lovc, Nucl. Instrum. Meth. 175, 535 (1980).

NP A99, $473 \quad$ J. van Klinken and L. M. Taff, Nucl. Phys. $A 99,473$ (1967).

NP A238, 149 R. Brissot, F. Schussler, E. Monnand, and A. Moussa, Nucl. Phys. A238, 149 (1975).

NP A246, $425 \quad$ Reference 37.

NP A250, 13 J. V. Kratz, H. Franz, N. Kaffrell, and G. Herrmann, Nucl. Phys. A250, 13 (1975).

NP A264, 1 J. A. Pinston, R. Roussile, H. Borner, H. R. Koch, and D. Heck, Nucl. Phys. A264, $1(19.76)$.

NP A285, $1 \quad$ K. Aleklett, E. Lund, G. Nyman, and G. Rudstam, Nucl. Phys. A285, 1 (1977).

NP A286, 403 E. Lund, K. Aleklett, and G. Rudstam, Nucl. Phys. A286, 403 (1977).

NP A321, $341 \quad$ T. Seo, T. Hayashi, Y. Miyatake, and K. Aoki. Nucl. Phys. A.321, 341 (1979)

NP A323, $205 \quad$ B. Fogelberg and P. Carle, Nucl. Phys. A323, 205 (1979).

INP A337, 285 P. de Gelder, D. de Frennnèe, E. Jacobs, H. 'Lherens, A. de Clercq, P. d'Hondt, K. Heyde, A. J. Deruytter, G. Tittel, N. Kaffrell, and N. Trautmann, Nucl. Phys. $A 337,285$ (1980).

NP A339, $74 \quad$ K. Summerer, N. Kaffrell, E. Stender, N. Trautmann, K. Broden, G. Skarnemark, T. Bjornstad, I. Haldorsen, and J. A. Maruhn, Nucl. Phys. A339, 74 (1980).

NP A339, 415 F. Schussler, J. A. Pinston, E. Monnand, A. Moussa, G. Jung, E. Koglin, B. Pfeiffer, R. V. F. Janssens, and J. van Klinken, Nucl. Phys. A339, 415 (1980).

NP A352, 1 G. Jung, B. Pfeiffer, P. Hungerford, S. M. Scott, F. Schussler, E. Monnand, J. A. Pinston, L. J. Alquist, H. Wollnik, and W. D. Hamilton, Nucl. Phys. A352, 1 (1981). 
NP A352, 157

NP A354, 77C

NP A368, 210

NSE 80,74

NUREG-39

PC- 1980

PETTEN77

PL 86B, 21

PR C3, 247

PR C14, 211

PR C17, 2185

PR C18, 1163

PR C19, 1504

PR C19, 1948

PR C22, 152

PR C22, 252
B. Fogelberg, K. Heyde and J. Sau, Nucl. Phys. A352, 157 (1981).

B. Jonson, Nucl. Phys. A354, 77c (1981).

P. Hoff and B. Fogelberg, Nucl. Phys. $A 368,210$ (1981).

Reference 23.

Reference 2.

L. E. Glendenin (Argonne National Laboratory) private communication.

Reference 25.

K. L. Kratz, H. Ohm, K. Summerer, M. Zendel, G. Jung, K. D. Wunsch, C. Ristori, J. Crancon, and S. G. Prussin, Phys. Lett. 86B, 21 (1979).

T. Nagarajan, M. Ravindranath and K. Venkata Reddy, Phys. Rev. C 3, 247 (1971).

H. Ahrens, N. Kaffrell, N. Trautmann and G. Herrmann, Phys. Rev. C 14, 211 (1976).

F. K. Wohn, K. D. Wunsch, H. Wollnik, R. Decker, G. Jung, E. Koglin, and G. Siegert, Phys. Rev. C 17, 2185 (1978).

M. L. Gartncr and J. C. IIill, Phys. Rev. C 18, 1463 (1978).

M. Epherre, G. Audi, C. Thibault, R. Klapisch, G. Huber, F. Touchard, and H. Wollnik, Phys. Rev. C 19, 1504 (1979).

G. Engler, Y. Nir-El, M. Shmid, and S. Amiel, Phys. Rev. C 19, 1948 (1979).

L. E. Glendenin, J. E. Gindler, I. Ahmad, D. J. Henderson, and J. W. Meadows, Phys. Rev. C 22, 152 (1980). See Table I.

G. Jung, B. Pfeiffer, L. J. Alquist, H. Wollnik, P. Hungerford, S. M. Scott, and W.

D. Hamilton, Phys. Rev. C 22, 252 (1980). 
PR C22, 2163 L. E. DeGeer and G. B. Holm, Phys. Rev. C 22, 2163 (1980).

PR C23, 331 J. K. Dickens and J. W. McConnell, Phys. Rev. C 23, 331 (1981). Cumulative yield for ${ }^{94} \mathrm{Y}$ determined using $\mathrm{A}_{\gamma}=56 \%$. is definitely smaller than expected (see Fig. 7 of this reference).

PR C23, 1726 W. L. Talbert, Jr., F. K. Wohn, L. J. Alquist, and C. L. Duke, Phys. Rev. C 23, $1726(1981)$.

PR C23, 2691 D. Otero, A. N. Proto, E. Duering, and M. L. Perez, Phys. Rev. C 23, 2691 (1981).

PRL 46, $1061 \quad$ Referenee 27.

RA 26, 127 J. Stachel, N. Kaffrell, E. Stender, K. Summerer, N. Trautmann, K. Broden, G. Skarnemark, T. Bjornstad, and I. Haldorsen, Radiochem. Acta 26, 127 (1979).

RMP 40, $659 \quad$ Reference 33.

RRL 21, $151 \quad$ P. Cavallimi and J. Blachot, Radiochem. Radioanal. Lett. 21, 151 (1975).

RRL 39, $107 \quad$ J. K. Dickens, Radiochem. Radioanal. Letl. 39, 107 (1979).

RUD77 G. Rudstam, "Status of Delayed Neutron Data," IAEA Report No. INDC(NDS)-87/GO + Sp (1978), p. 567.

TIC-11026 Reference 18.

TOI-7 Reference 29.

ZAED Ketereñcè $2 \dot{6}$.

ZP 263, $435 \quad$ K. L. Kratz and G. Herrmann, Z. Phys. 263, 435 (1973).

ZP A273, 283 G. Bailleul, J. P. Bocquet, H. Schrader, R. Stippler, B. Pfeiffer, M. Asghar, C. Chauvin, J. P. Gautheron, J. Grief, G. Siegert, P. Armbruster, H. Ewald, J. Blachot, E. Monnaud and F. Schussler, Z. Phys. A 273, 283 (1975). 
ZP A275, 359 P. Fettweis and P. del Marmol, Z. Phys. A 275359 (1975).

ZP A283, 105 T. A. Khan, W. D. Lauppe, K. Sistemich, H. Lawin, G. Sadler, and. H. A. Selic, Z. Phys. A 283, 105 (1977).

ZP A284, 95 R. Stippler, F. Munnich, H. Schrader, J. P. Bocquet, M. Asghar, G. Siegert, R. Decker, B. Pfeiffer, H. Wollnik, E. Monnand, and F. Schussler, Z. Phys. A 284, 95 (1978).

ZP A285, 287 R. Stippler, F. Munnich, H. Schrader, K. Hawerkamp, R. Decker, B. Pfeiffer, H. Wollnik, E. Monnaud, and F. Schussler, Z. Phys. A 285, 287 (1978).

ZP A287, 45 J. Crancon, C. Ristori, H. Ohm, W. Rudolph, K. L. Kratz, and M. Asghar, Z. Phys. A 287, 45 (1978).

ZP A288, $105 \quad$ K. D. Wunsch, R. Decker, H. Wollnik, J. Munzel, G. Siegert, G. Jung, and E. Koglin, Z. Phys. A 288, 105 (1978).

ZP A288, 319 E. Koglin, G. Jung, G. Siegert, R. Decker, K. D. Wunsch, and H. Wollnik, Z. Phys. A 288, 319 (1978).

ZP A289, 197 H. A. Selic, G. Sadler, T. A. Khan, W. D. Lauppe, H. Lawin, K. Sistemich, E. Monnand, J. Blachot, J. P. Bocquet, and F. Schussler, Z. Phys. A 289, 197 (1979).

ZP A289, 407 U. Keyser, H. Berg, F. Munnich, K. Hawerkamp, H. Schrader, B. Pfeiffer, and E. Monnand, Z. Phys. A 289, 407 (1979).

ZP A290, 311 C. Ristori, J. Crancon, K. D. Wunsch, G. Jung, R. Decker, and K. L. Kratz, Z. Phys. A 290, 311 (1979).

ZP A294, $35 \quad$ R. Decker, K. D. Wunsch, H. Wollnik, E. Koglin, G. Siegert, and G. Jung, Z. Phys. A 294,35 (1980). 
ZP A299, 209

ZP A300, 249

ZP A 300,289

ZP A301, 165
I. D. U. Ebong and R. R. Roy, Z. Phys. A 299, 209 (1981).

U. Keyser, F. Munnich, B. Pahlmann, and B. Pfeiffer, Z. Phys. A 300, 249 (1981).

P. Hoff, K. Aleklett, E. Lund, and G. Rudstam, Z. Phys. A 300, 289 (1981).

R. Decker, K. D. Wunsch, H. Wollnik, G. Jung, M. Munzel, G. Siegert, and E. Koglin, Z. Phys. A 301, 165 (1981). 


\section{APPENDIX: FORTRAN SUBROUTINE BETASP}

The description of this subroutine is given in the main body of the text. The data file is to be placed on "Unit 28 " for sequential input. The records of the data file are discussed in the subsection, "The Data File," and the only item of clarificaton here is that all of the "empty" lines shown in the table of this report were added to the actual data file solely for the purpose of providing added clarity to the printed output for this report; these "empty" lines do not exist in the file available from the Oak Ridge National Laboratory Radiation Shielding Information Center (RSIC).

This subroutine, as well as a short main routine for illustrative purposes (and not listed here), accompany the data transmitted by RSIC, along with documentation needed to extract the information from the medium of transmittal. 
SUBROUTINE BETASP(IZ, IA, DE, KMX, E, ESUM, ESUMN, SSUM, SSUMN, NAME, TH)

PURPOSE IS TO COMPUTE BETA-RAY SPECIRUM

$I Z=P R O T O N$ NUMBER OF BETA EMITTER, INPUT

IZ+400 IMPLIES ISOMER OF BETA EMIITER

IA $=$ MASS NUMBER OF BETA EMITIER

$D E=B I N W I D T H$ ENERGY, MEV. INPUT NUMBER.

$E=E N E R G Y$ OF BIN(S) OF SPECTRUM, MEV, MIDPOINT

ESUM $=$ YIELD (PER BIN) TOTAL SPECTRUM

ESUMN = NEUTR INO SPECTRUM

SSUM =TOTAL BETA ENERGY -- SUM OF YIELD*ENERGY

SS.UMN = TOTAL NEUTRINO ENERGY

NAME = ALPHANUMERIC DESCRIPTOR OF BETA EMITTER

TH=HALF LIFE, SEC

3

DIMENSION EMAX $(10), \operatorname{IF}(10), B(10), C A(10), C B(10), C C(10)$

DIMENSION ENE $(1500), E(1500)$, ESUM $(1500)$, ESUMN $(1500)$, ENEN(1500)

DATA NSIR/5H ISOM/, NON/5H

DO $12 \quad I=1,1500$

$12 \operatorname{ESUM}(I)=0.0$

$K M X=0$

$S S U M=0.0$

SSUMN $=0.0$

CALL SEARCH( I $Z, I A, N B, N A M E, E M A X, T F, B, C A, C B, C C, T H)$

IF (NB.GT.O) GO TO 7

15 WRITE $(6,17)$ IZ, IA

17 FORMAT (; * *ERROR BETASP, IZ $=1$ I $4,1, I A=1 I 5 /)$

$T H=-1.0$

RETURN

$7 \quad N A M Z=N O N$

IF (IZ.LT.400) GO TO 1

$I Z=I Z-400$

NAMZ $=$ NSTR

$1 \quad Z=F \operatorname{LOAT}(\mathrm{I} Z)+1.0$

IF (EMAX (1).LT.0.0) GO TO 34

DU $8 \quad N=1, N B$

$B R=0.01 * B(N)$

IF $(\operatorname{IF}(N)+3) \quad 40,41,41$

40 CONIINUE

C TO HANDLE CONV. ELECTRONS, UNSMEARED -

$M=I F I X(E M A X(N) / D E)+1$

$\operatorname{ESUM}(M)=\operatorname{ESUM}(M)+B R$

$E(M)=D E *(F L O A T(M)-0.5)$

IF (KMX.LT.M) KMX $=M$

GO TO 8

41 CONTINUE

$W 0=1.0+E M A X(N) / 0.511$

$E(1)=0.5 * D E$

$S=0$.

$\mathrm{K}=1$

$S N=0$.

$2 \quad E K K=E(K)$

$D E K=D E$

IF $\left(\left(E(K)+0.5^{*} D E\right)\right.$. LT. EMAX (N)) GO TO 5

$E K K=0.5 *(E(K)-0.5 * D E+E M A X(N))$ 


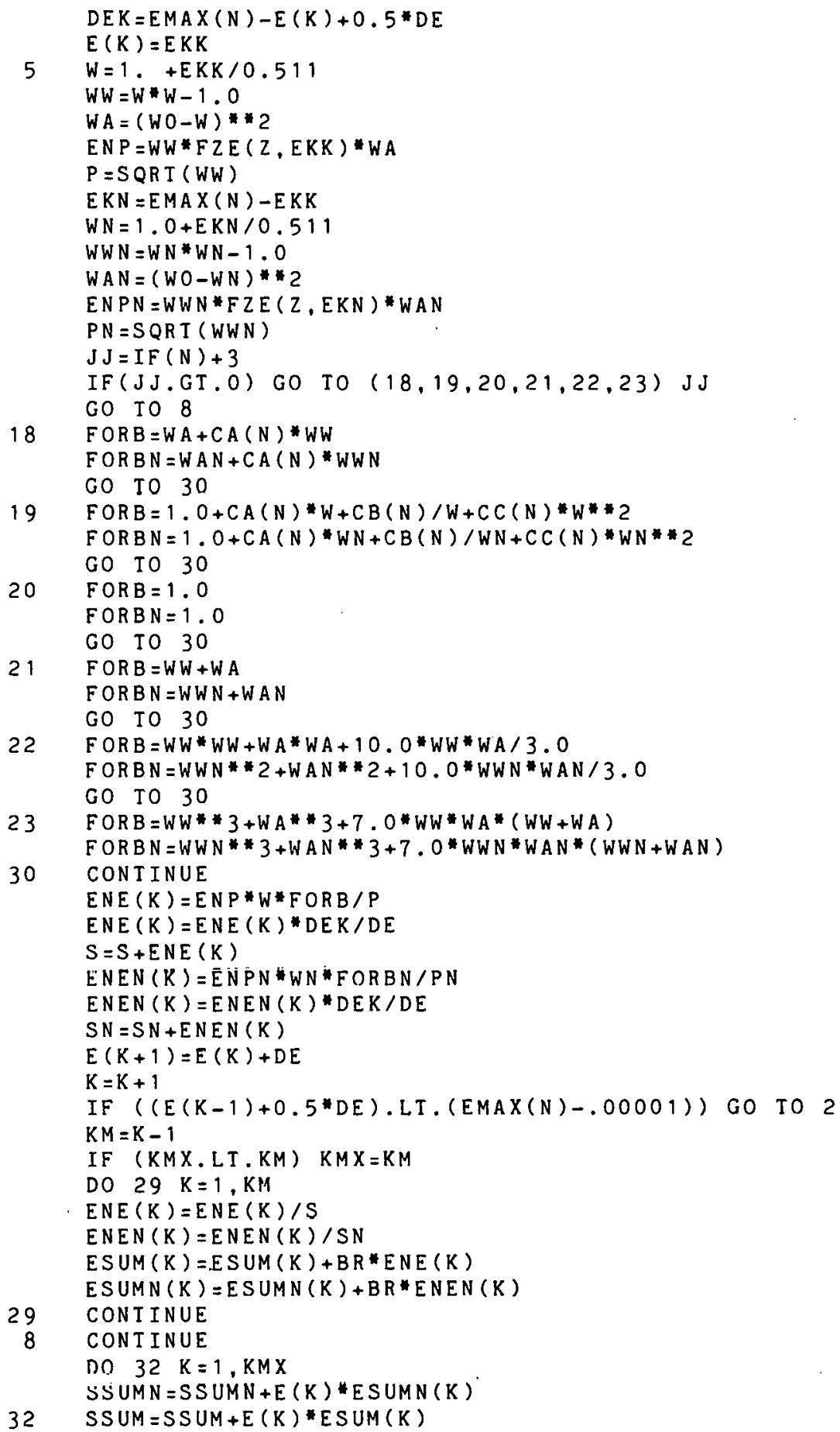




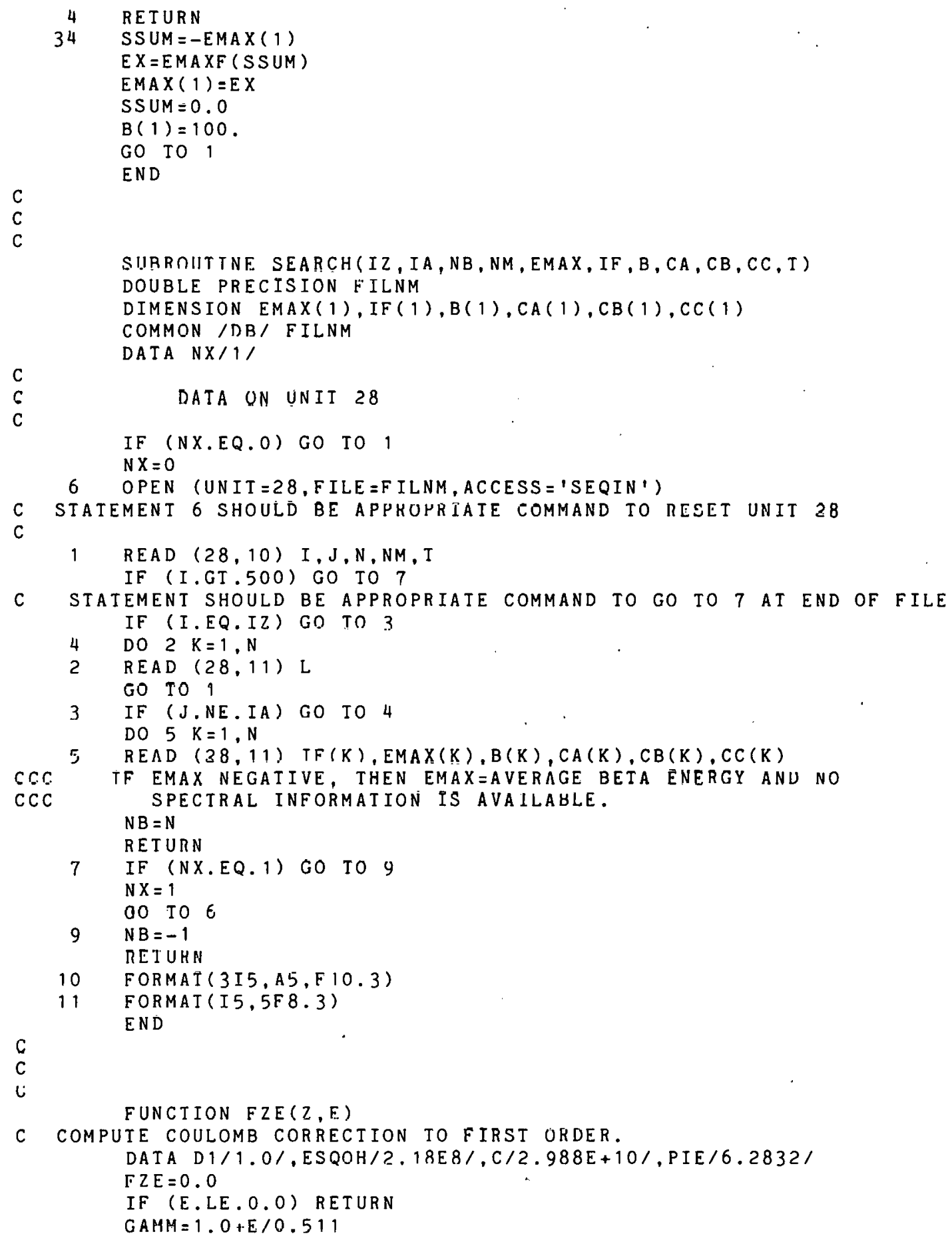




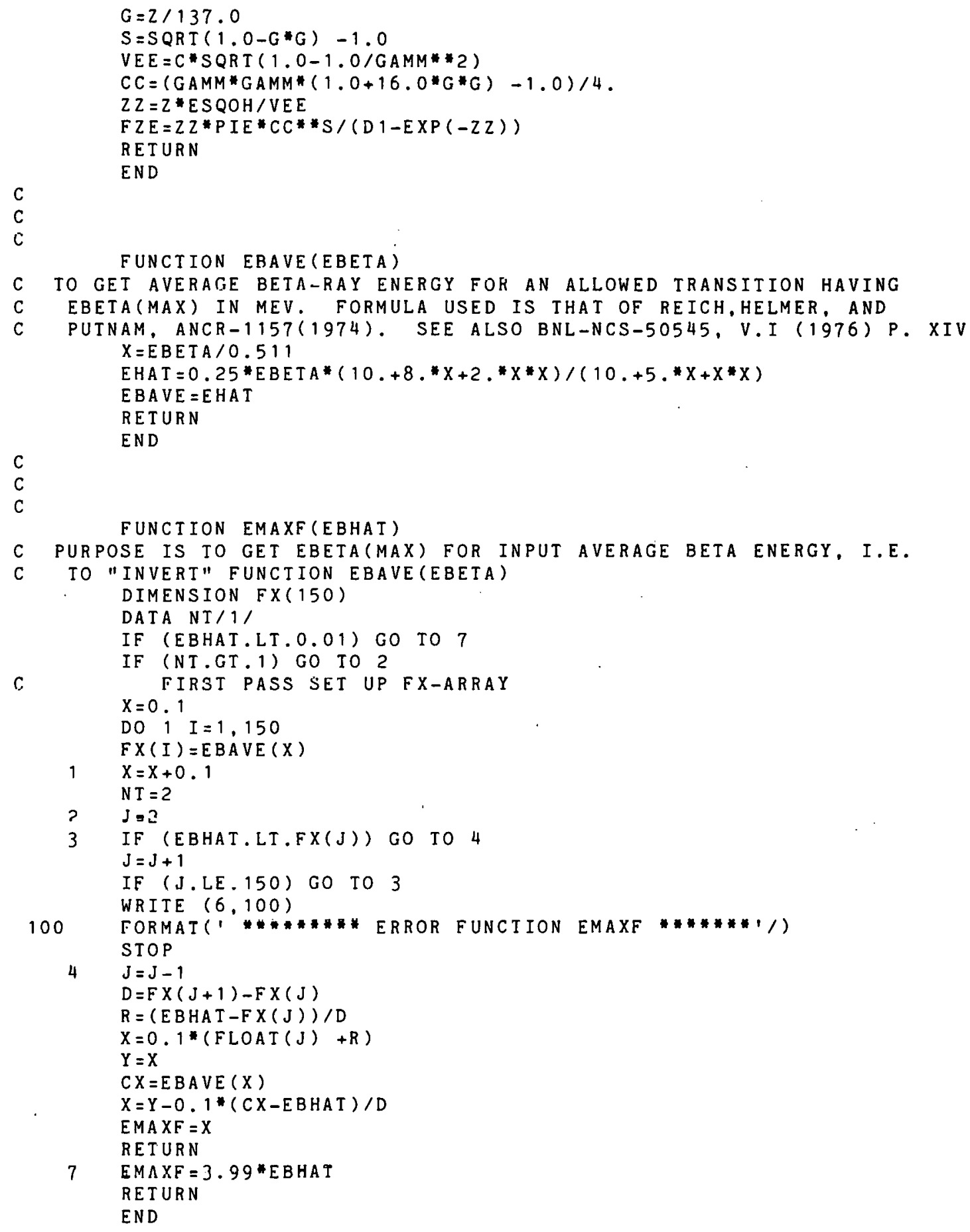


THIS PAGE

\section{WAS INTENTIONALLY LEFT BLANK}




$$
\begin{aligned}
& \text { DoNoT } \\
& \text { Microfilm }
\end{aligned}
$$

97

ORNL/TM-8285

\section{INTERNAL DISTRIBUTION}

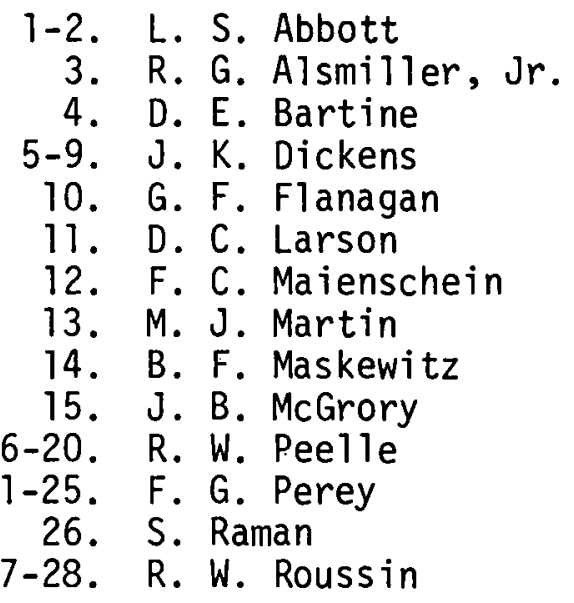

29. P. H. Stelson

30. C. R. Weisbin

31. A. Zucker

32. P. W. Dickson, Jr. (consultant)

33. H. J. C. Kouts (consultant)

34. W. B. Loewenstein (consultant)

35. Richard Wilson (consultant)

36-37. Laboratory Records

38. Laboratory Records-RC

39. ORNL Patent Office

40. Central Research Library

41. ORNL Y-12 Technical Library Document Reference Section

\section{EXTERNAL DISTRIBUTION}

42-68. Technical Information Center (TIC)

69. Office of Assistant Manager for Energy Research and Development, Department of Energy, Oak Ridge Operations, Oak Ridge, TN 37830

70. S. L. Whetstone, Division of Nuclear Sciences, Office of Basic Energy Sciences, U.S. Department of Energy, Rm G-355, Washington, D. C. 20545

71. P. Vogel, California Institute of Technology, Department of Physics, Pasadena, CA 91125

72. F. T. Avignone III, Department of Physics, University of South Carolina, Columbia, SC 29208

73. T. R. England, Los Alamos National Laboratory, P. 0. Box 1663, Los Alamos, NM 87545

74. R. E. Schenter, Nuclear Analys is Section, MSIN-W/A-4, Westinghouse Hanford Company, P. O. Box 1970, Richland, WA 99352 